\title{
Dabis Attila
}

\section{Misbeliefs about Autonomy}

The Constitutionality of the Autonomy of Szeklerland 
Corvinus University of Budapest

Institute for International Studies

Supervisor: Dr. Elisabeth Kardos Kaponyi

(C) Dabis Attila, 2017

All rights reserved 


\section{Corvinus University of Budapest}

\section{International Relations Multidisciplinary Doctoral School}

International and Security Studies Subprogram

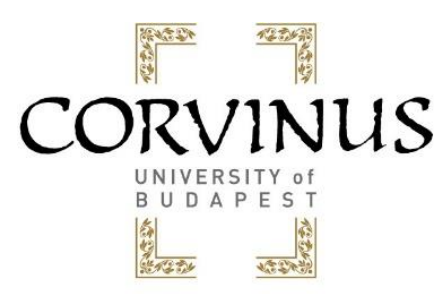

\section{Misbeliefs about Autonomy}

The Constitutionality of the Autonomy of Szeklerland

Ph.D. Dissertation

\section{DABIS Attila}

Budapest, 2017 



\section{Contents}

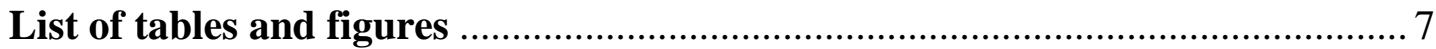

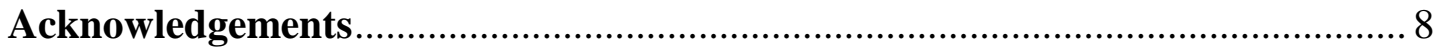

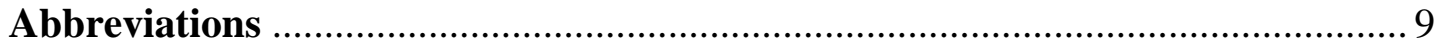

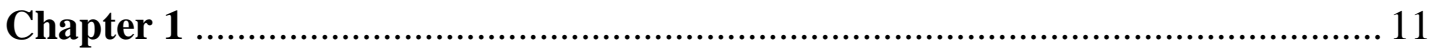

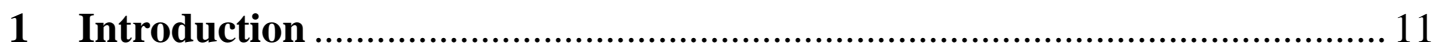

1.1 Relevance and structure of the analysis ................................................. 11

1.2 Theoretical and methodological framework ............................................ 13

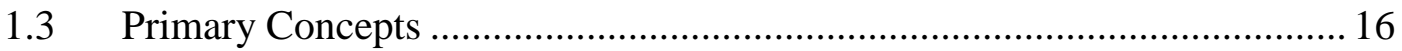

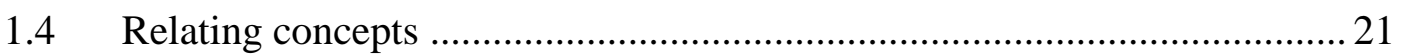

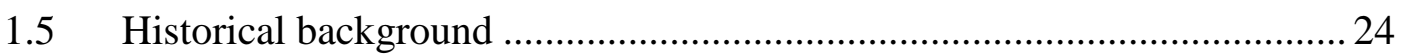

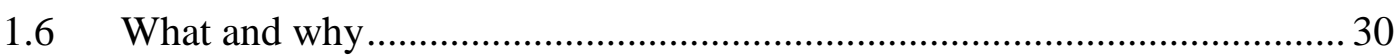

1.6.1 Basic features of the Draft Law on the Autonomy of Szeklerland .......... 30

1.6.2 Driving forces behind Szekler autonomy aspirations ............................ 32

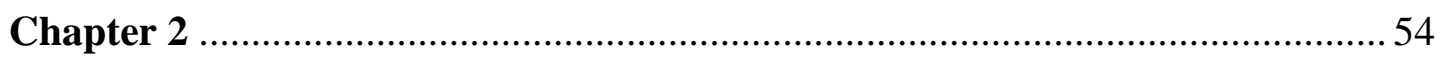

2 Autonomy and the Constitution of a Nation state ...................................... 54

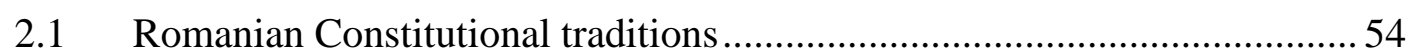

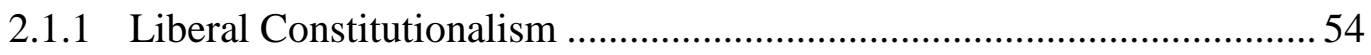

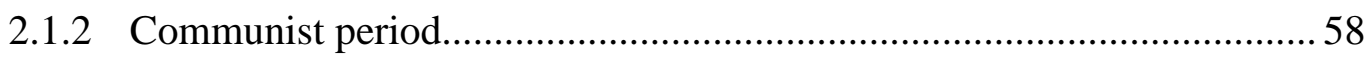

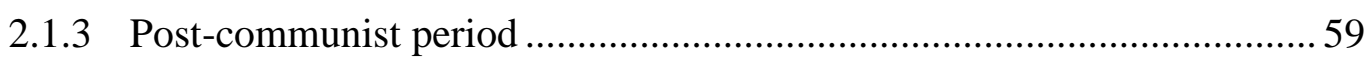

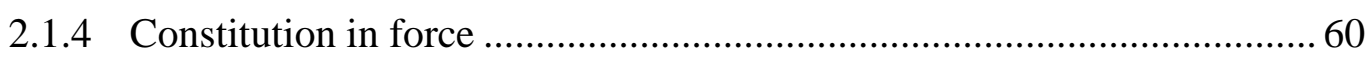

2.2 Opinion No. 102/2004 - The essential summary of all arguments.............. 62

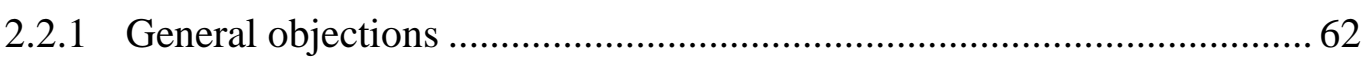

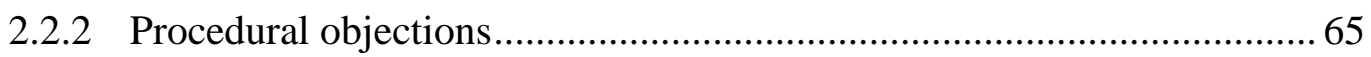

2.3 Decision No. 80/2014 of the Constitutional Court of Romania rejecting the constitutional amendments proposed by the Special Committee of the Parliament The Constitutional Court and the recognition of the national ideal........................66

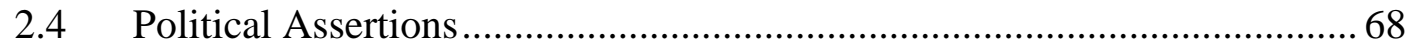

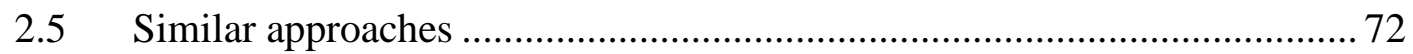

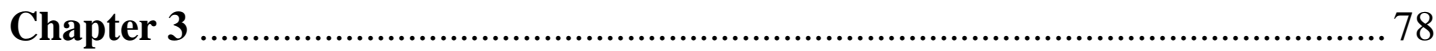

3 Deconstructing the constitutional barrier .................................................... 78

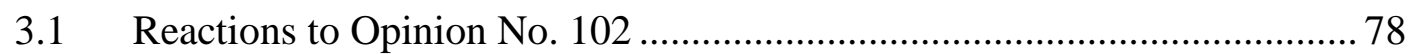

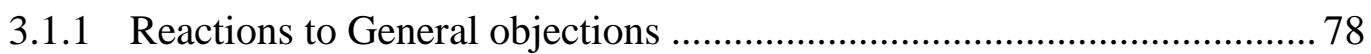

3.1.2 Reactions to Procedural objections ........................................................ 86 


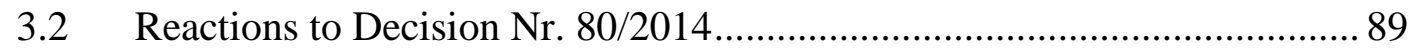

3.3 The Eye of the Duck - Legal entrenchment................................................ 91

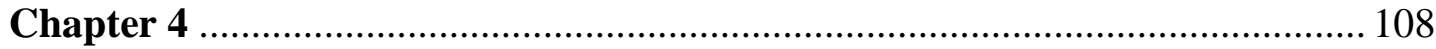

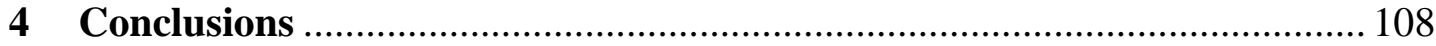

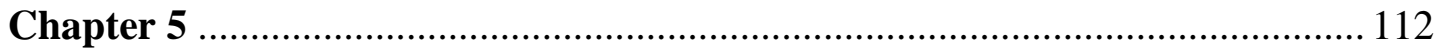

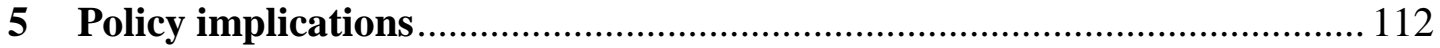

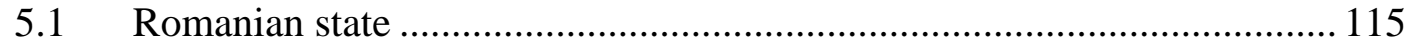

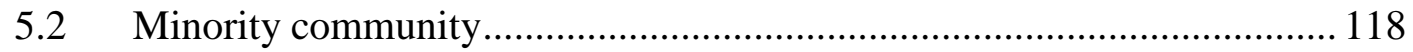

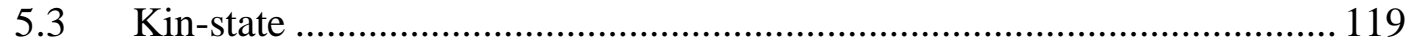

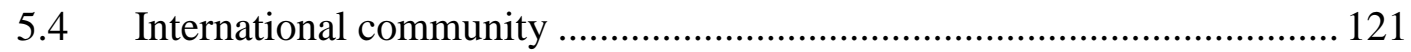

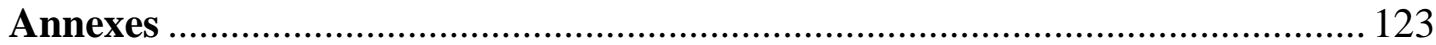

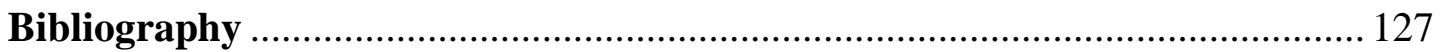

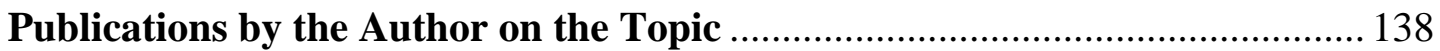




\section{List of tables and figures}

\section{Tables}

Table 1 Demographic trends of Hungarian minority communities living in countries adjacent to Hungary (1989-2011)

\section{Figures}

Figure 1 Administrative borders of the Austro-Hungarian Empire 123

$\begin{array}{lll}\text { Figure } 2 \text { Territorial changes due to the 1st, and 2nd Vienna Arbitrations } & 124\end{array}$ in 1938 , and 1940

Figure 3 Changing borders of the Hungarian Autonomous Province in communist Romania

$\begin{array}{lll}\text { Figure } 4 & \text { Ethnic distribution of Transylvania (1910-1977) }\end{array}$

Figure 5 Ethnic distribution of Transylvania (2002) 


\section{Acknowledgements}

I can consider myself honoured to have been supervised by dr. Elisabeth Kardos Kaponyi, whose delicate balance of encouragement and criticism helped me to keep my scientific focus on track. I am also pleased to acknowledge the scientific and/or theoretical support of a number of researchers, academics, and university professors as well as diplomats and politicians across Europe. In alphabetical order these are: Bakk Miklós, Bárdi Nándor, Bárður Larsen, Blahó András, Graham Donnelly, Gordos Árpád, Günther Rautz, GyörgyMózes Árpád, Heidi Öst, Izsák Balázs, Kántor Zoltán, Kardos Gábor, Kiss Eszter, Lauri Hannikeinen, Markku Suksi, Richard Berry, Sarah Stephan, Sergiu Constantin, Tom Mullen, Varga Attila.

I had the privilege to base this dissertation on research conducted in some of the most renowned scientific centres, such as the European Academy of Bolzano/Bozen (EURAC), the University of Glasgow, or the Åbo Akademi in Finland. Furthermore, the methodological guidelines of the Corvinus University of Budapest proved to be particularly useful throughout the whole research process.

Equally essential was the financial support provided by the Balassi Institute, the Erasmus Traineeship scheme of the EU, as well as the Szekler National Council, through which I was able to conduct my research abroad.

Writing this dissertation entailed considerable periods of absence from home, placing additional burden on my relatives. Consequently, I express my most sincere gratitude to my family, and most of all to my wife Melinda, for her unconditional support and patience throughout this long process. 


\section{Abbreviations}

CCR

CCS

CI

CR

CS

CLRA

$\mathrm{CoE}$

DAHR

DIICOT

DNA

DOM-TOM

DL

DSF

ECHR

EU

FCPNM

ICCPR

ICESCR

LCM
Constitutional Court of Romania

Constitutional Court of Spain

Constitution of Italy

Constitution of Romania

Constitution of Spain

Congress of Local and Regional Authorities of the Council of Europe

Council of Europe

Democratic Alliance of Hungarians in Romania

Directorate for Investigating Organized Crime and Terrorism (Direcția de Investigare a Infracțiunilor de Criminalitate Organizatăși Terorism)

National Anticorruption Directorate (Direcţia Naţională Anticoruptie)

Overseas Departments and Territories (départements et territoires d'outre-mer)

Draft Law on Autonomy of the Szekler National Council

Day of the Szekler Freedom

European Convention on Human Rights

European Union

Framework Convention for the Protection of National Minorities

International Covenant on Civil and Political Rights

International Covenant on Economic, Social and Cultural Rights

Legislative Consent Motion 
NGO Non-governmental organization

NSAC New Statute of Autonomy of Catalonia

OSCE Organization for Security and Co-operation in Europe

PACE Parliamentary Assembly of the Council of Europe

PD Democratic Party (Partidul Democrat)

PDL National Liberal Party (Partidul Naţional Liberal)

PSD Social Democratic Party (Partidul Social Democrat)

SzNC Szekler National Council

SRI Romanian Intelligence Service (Serviciul Român de Informaţii)

TA Territorial Autonomy

UN United Nations

Venice Commission European Commission for Democracy through Law 


\section{Chapter 1}

\section{Introduction}

\subsection{Relevance and structure of the analysis}

With approximately 650.000 members, the Hungarian-speaking Szekler community is one of the largest nationalities of Europe that has not yet obtained any kind of autonomy. The many public protests, demonstrations, the numerous drafts, programs and manifestos of Hungarian political organizations, scientific institutions or NGOs show a permanent discontent of the Hungarian minority regarding their legal status in Romania. Given that such discontent was present in different forms ever since the territorial changes after the First World War, the question of the Hungarian minorities in the successor states of the Austro-Hungarian Empire (see Figure 1) is often characterized as one of the major unresolved questions of Central and Eastern Europe. ${ }^{1}$ It is no great surprise, however, that this opinion is not widely shared by state officials of countries having extensive Hungarian minority communities. As a matter of fact, it is the most common viewpoint one would hear that the minority question in Romania is solved in an exemplary manner. Any subject which continues to polarize the public opinion so vividly is worthy of scientific analysis. Indeed, the issues discussed in this dissertation raise many questions worthy of further scientific research. Larger international scientific attention, however, is made difficult by the fact that some of the legal materials most relevant for a better understanding of the case are only available in either Romanian or Hungarian. Even though this dissertation does not provide the full English translation of these legal materials, the extensive summaries that it contains will hopefully prove to be a contribution to foster more international scientific attention.

The following chapter provides the methodological underpinnings and the theoretical framework of the research, including most importantly the rationale behind the case selection. The same chapter also offers the explanation of the primary concepts used throughout the dissertation, and the concepts that are in close relation to these. Furthermore, a brief historical overview of the subject-matter is provided to increase the

\footnotetext{
${ }^{1}$ See e.g.: Arday (2010), p. 1.
} 
contextual understanding of the Szekler case. Chapter two presents the arguments of the various Romanian authorities against autonomy. A certain pattern emerges from the presented official documents, emphasizing similar observations why autonomy is in contradiction with the constitution. The main legal argument - that autonomy would eliminate the unity and the indivisibility of the state - is often complemented with theoretical arguments on sovereignty, and procedural observations on the feasibility of autonomy within the Romanian legal system. All of these considerations come under scrutiny, as chapter three explores the possible answers and counter-responses to nationstate arguments, based mainly on doctrinal analysis of legal material, comparison of the experience of other European states and their autonomous regions, as well as relevant scientific literature, and the commitments that accrue from international documents ratified by Romania. While the former three groups of sources present a large variety of arguments about autonomy being an effective and flexible solution for multi-ethnic states to accommodate minority aspirations in a democratic manner, while also preserving the territorial integrity of the state at the same time, the latter sources are of relevance as they outline the extent to which Romania is encouraged or even obliged to seek more effective ways of minority protection and power-sharing. These two chapters outline the misconceptions, as well as the discrepant perceptions of the majority and the minority about state, nation, sovereignty, autonomy, and their relation to one another. The conclusions of the study are split into two chapters. While chapter four reviews the findings of the research itself, chapter five considers the policy implications of the analysed case for the wider public life, hoping to become a useful read to academics and decision-makers alike.

The documents that served as a basis to reconstruct the "nation-state position" allude to the presence of a strong tacit consensus within the Romanian political culture, capable of shaping public policy decisions. Most certainly, it is due to the impact of this tacit agreement that to date no in-depth analysis has been carried out concerning the feasibility of incorporating a territorial autonomy into the current Romanian legal system. The issue pops up every now and then, depending on the political discourse in the country, but extensive scrutiny has so far avoided the topic. In this respect, the novelty of this dissertation is twofold. The constitutional aspects of a Szekler autonomy arrangement in themselves were largely neglected within academia, leaving behind a gap that is very much ripe for scientific review. Furthermore, even if the topic was discussed, it was 
mostly done within the framework of the "nation-state discourse", and all the natural conceptual restraints thereof. This dissertation attempts to surpass these constraints, along with some of the most widespread, albeit false presuppositions and misconceptions surrounding the issue at hand. Ultimately, we invite the reader to engage in a mind game in order to deconstruct the "constitutional myth" regarding autonomy. Hopefully, by the time one reads through this dissertation, he will have been convinced that there are indeed no constitutional obstacles to establish a territorial autonomy within Romania. There are only political obstacles, which tend to be wrapped and presented as legal ones.

\subsection{Theoretical and methodological framework}

On 30 March 2004, and 12 October 2005 respectively, the Chamber of Deputies of the Parliament of Romania rejected the Draft Law on the Autonomous Status of Szeklerland (hereinafter, Draft Law). Opinion No. 102/2004 of the Legislative Council of the Parliament argues in favour of the rejection, as the Draft Law is contrary to the constitution for various reasons (an opinion that was reinforced in 2005). ${ }^{2}$

This theoretical conception arises from the misinterpretation of the connection between state and autonomy, and as such can be falsified by the experience of the functioning autonomies as well as by international law and the corresponding scientific literature. Consequently, my main hypothesis is that the territorial autonomy of Szeklerland does not contradict the Constitution of Romania (CR).

The applied methodology to prove this hypothesis is twofold. One of the main assertions of the dissertation is that there are in fact no provisions in the Romanian legal system that constitute a material legal obstacle for the establishment of an autonomous territorial entity. The only obstacle that exists is a political one, which derives from the dissenting interpretation of the same legal material. In this sense, the dissertation is largely a doctrinal legal analysis that first explores the misinterpretations of autonomy by Romanian authorities, then it identifies a dissenting interpretation and presents evidence supporting it. Parallel with this, a comparative legal analysis is conducted, based on the

\footnotetext{
${ }^{2}$ According to Art. 79 (1) of the Constitution, the Legislative Council shall be an advisory expert body of the Parliament, which advises draft normative acts for the purpose of a systematic unification and coordination of the whole body of laws. It shall keep the official record of the legislation of Romania.
} 
relevant legal material, that is: The Constitution of Romania; Laws of Romania; The Opinion of the Legislative Council of the Parliament of Romania on the rejection of the Draft Law on the Autonomous Status of Szeklerland; Decision No. 80 of the Constitutional Court rejecting the constitutional amendments proposed by the Special Committee of the Parliament, issued in February, 2014; relevant decrees of the Prefect's of Romania; the Statutes of European autonomies, as well as the constitutions and laws of their host countries; international legal material ratified by Romania. While the scope of the analysis remains mostly in the discipline of law, more specifically comparative constitutional law, one cannot deny the basic fact that autonomous arrangements are not legally airtight constructions, but ones that are highly contingent on political developments. The current phase of the Szekler autonomy struggle in particular is a highly politicised subject. In this sense, the dissertation is positioned at the cross point of law and political science.

The case selection for the study was done bearing in mind the main features of the specific region (Szeklerland) and its host country (Romania) that serve as the basis for comparison. In this respect, I will write about territorial autonomies (given the fact that Szekler autonomy aspirations pertain to territorial self-government, as opposed to other forms of autonomy), in regions where a specific minority represents the majority, and which exist in unitary states (as opposed to federal ones). Applying these methodological constraints, the core group of selected cases can be identified as follows: South-Tyrol in Italy, the Basque Country, and Catalonia in Spain, Scotland in the United Kingdom, the Åland Islands in Finland. These main cases, which are relevant in all the questions raised by documents outlined in Chapter 3, will be supplemented by examples that are important only in some particular aspects. More specifically, state approaches to autonomy that are similar to Romania's will be mentioned, like the case of Corsica in France, and the Russian community in Estonia. In particular, French reactions to, and arguments against Corsican autonomy have remarkable similarities with Romanian arguments. ${ }^{3}$ The legal entrenchment of the autonomy of the Faroe Islands and Greenland in Denmark will be discussed, as well as the experience of the only minority territorial autonomy of Central

\footnotetext{
${ }^{3}$ Due to the fact that Corsica hasn`t still received law-making powers, hence the Corsican Assembly has only limited authority to adapt regulations in its areas of administrative competences and can propose modifications to specific legislation and regulations, most of the scholars do not consider Corsica to be an autonomous entity. See, e.g.: Suksi (2011), pp. 16-17. Nonetheless, this case is relevant from the statereaction point of view, and will be discussed exclusively from that perspective.
} 
and Eastern Europe, Gagauzia. While federal states in general fall outside the scope of the analysis, some brief references to the special legal entrenchment of autonomies in federal states will be mentioned only for the purpose of illustrating the manifold ways an autonomy arrangement can be embedded in a given constitutional system.

In practice content analysis of legal texts and relevant scientific literature was performed. In order to deepen the understanding of the functioning of regional autonomy, and the way the various autonomy arrangements fit into the legal systems of the given host countries. Starting from 2011, 3 to 4 months long research visits were conducted in South-Tyrol, Scotland, and Finland under the auspices of the European Academy of Bolzano/Bozen (EURAC), the University of Glasgow, and Åbo Akademi respectively, enabling the implementation of interviews with academics, lawyers, as well as with diplomats, and representatives. Shorter visits to Wales, the Basque Country, and Catalonia were also made carried out. Conferences, scientific workshops, and research seminars attended during the course of the research provided me with the opportunity to deepen my understanding of the research topic in a discursive way.

Regarding the conclusions of this study, my main scientific expectation is to prove that territorial autonomy, as an institutional arrangement, in general does not contradict the constitutional order of Romania. The misbeliefs surrounding autonomy can be traced back to a tacit agreement regarding the aspirations of the Hungarian minority, and the national character of the Romanian state. If one puts aside these historically rooted reflexes and resentments, and takes into account the international legal documents ratified by Romania regarding minorities, and interprets the country's domestic legislation accordingly, then the road is paved for recognizing the legitimate nature of autonomy aspirations. This is at stake with this hypothesis: whether or not it is possible to remove a seemingly robust obstacle, towering in front of a legitimate minority aspiration. Consequently, the dissertation needs also to assess the corresponding action relevant actors can engage in to achieve this effect.

Besides this main concern, there is another dimension of the question that needs to be addressed. If we verify the general assumption that territorial autonomy as an institutional solution is in conformity with the constitution, does that automatically mean that the draft law on the autonomy of Szeklerland is implementable without having to amend the constitution first? As I will argue, when it comes to the specific statute draft, 
some legal obstacles arise, whose solution would require a dialogue between the given minority community and the central state. Additionally, even if there was a possibility to implement a statute without the amendment of the constitution, it might result in an autonomy without adequate legal entrenchment, which could undermine the stability of the whole autonomy arrangement.

\subsection{Primary Concepts}

Reading the scientific literature on autonomy and self-governance, one cannot help but notice the diversity of concepts, often describing seemingly identical phenomena. One could easily write a whole book, listing only the literature that provides extensive review on the terminology used also in this analysis. Given the fact that the dissertation revolves mainly around legal issues, I use the definition of concepts existing in the relevant hard or soft law (either domestic or international), not neglecting the manifold definitions provided by the scientific literature.

Autonomy: Defining the most relevant concept for this dissertation already poses challenges in the sense that the term autonomy has not yet been explicitly defined in any international legal material. The concept of autonomy has appeared in many different disciplines (sociology, psychology, political science, law), described by a diverse range of typology. Generally, autonomy refers to self-government of a group or territory within a state, and can be divided, most simplistically, into territorial and personal autonomy. The main difference between these two, according to Brunner and Küpper, lies in the legal subject. While the former is based on the whole population of a territorial unit, the latter one is based on the members of a specific minority. ${ }^{4}$ Lapidoth adopts a similar approach, and completes these basic two categories with that of sovereignty, suggesting an eclectic description of autonomy. Cultural (or personal) autonomy might be given to groups whose members are dispersed geographically throughout the population. Sovereignty refers to state sovereignty as possessing absolute authority within the state's boundaries, while territorial political autonomy in this sense is "an arrangement aimed at granting to a group that differs from the majority of the population in the state, but that constitutes the majority in a specific region, a means by which it can express its distinct

\footnotetext{
${ }^{4}$ Brunner et al (2004), p. 474.
} 
identity." ${ }^{5}$ In an attempt to provide a terminology more suitable to describe the numerous forms of autonomy, Tkacik differentiates between five levels. Rejecting the approach of Lapidoth that „collapses personal and cultural autonomy”, he distinguishes these two adding that unlike cultural autonomy, personal autonomy can mean the guarantee of certain basic rights to the individual per se, and not as a member of a specific group. Furthermore, Tkacik also tries to avoid the use of territorial autonomy, as a "vague and inconsistent" term that "suffers from varied usages", and identifies instead functional, administrative, and legislative autonomy, concentrating on the scope of autonomous competencies. ${ }^{6}$ Heintze differentiates between 4 types of autonomy. ${ }^{7}$ Territorial autonomy, understood as an arrangement that comprises of self-government organs vested with competences that are of particular importance to the minority or group, and three subcategories of non-territorial autonomy. These latter three are: cultural autonomy (the self-government of cultural affairs by a distinct group or minority), personal autonomy (where the subjects of the autonomous competencies are persons, and not a group), and functional autonomy (the transfer of specific state functions to private organizations administered by a minority group). ${ }^{8} \mathrm{~A}$ similar approach is adopted by Légaré and Suksi when assessing the spatial and the normative scope of autonomy arrangements. Accordingly, they differentiate between territorial autonomy with legislative competencies (like the Åland Islands, Catalonia or South Tyrol), territorial autonomies with regulatory powers only (like Corsica or Wales, adding that these selfgoverning territories may not be characterised as autonomies insofar as we treat legislative powers as a prerequisite of the concept of autonomy), non-territorial autonomies with legislative powers (difficult to find concrete examples, one would be the Millet system of Turkey), and finally non-territorial autonomies with regulatory powers (mainly all cultural autonomies fit in this category, like the ones existing in Estonia, Hungary or Slovenia). ${ }^{9}$

Provided that autonomous arrangements most often accrue in response to minority claims, the term 'minority territorial autonomy' is also used. ${ }^{10}$ Tóth describes this as ,an

\footnotetext{
${ }^{5}$ Lapidoth (1997), p. 33.

${ }^{6}$ Tkacik (2008), p. 370.

${ }^{7}$ A typology also used by Weller et al (2010), pp. 2-6.

${ }^{8}$ Heintze (1998), pp. 18-24.

${ }^{9}$ Légaré et al (2008), pp. 146-147.

${ }^{10}$ See e.g.: Henders (2010), p. 12.
} 
area of a given state that has relatively exact political and administrative borders and its population is being conferred with the power of legislation and law-enforcement at least in some fields having relevance to the goal of the autonomy, aiming first of all the preservation of the special identity of the minority community in a majority situation of the autonomous territory". ${ }^{11}$

Even when narrowing down the scope of analysis to autonomies and their relation to constitutional law - the main concern of this dissertation - one finds a large variety of typologies. Among these, throughout the dissertation I used the typology of Suksi who distinguishes between 6 possible ways of legally entrenching an autonomy arrangement: regional entrenchment (possibility of regional reaction to amending the statute of autonomy), special entrenchment (special amendment rule of the statute), general entrenchment (regulating autonomy in the national constitution), semi-general entrenchment (regulating autonomy at the level of organic laws), international entrenchment (having two types: a) open: without a formal treaty such as the Ålandislands, and b) treaty based: where the autonomous competencies are being enshrined in a treaty such as the case of South Tyrol), entrenchment under the right to selfdetermination (given that the population of the area can be viewed as a people). ${ }^{12}$ Hannikainen lists the constitutional criteria of every autonomy arrangement. These are: a) the autonomous status should be inscribed in the constitution of the state or at least in legislation, above normal laws in the hierarchy of norms; b) presence of a democratically elected legislative body and a local government that is subject to scrutiny of this legislature; c) jurisdiction should be either exclusive or shared, with the possibility from the side of the autonomous region to insert his preferences; d) the different language, if there is one, should have official status in the region; e) the creation of a special bilateral organ composed of delegates of the state and autonomous region dedicated to address contentious issues; f) opportunity for the autonomous region to effectively take part in the decision-making process on the national level; g) the involvement of local court in the autonomous machinery; h) sufficient taxation powers; i) the right to external cooperation; j) limited powers to the official, representing the State within the autonomous region. This typology discusses the democratic prerequisites of autonomy, showing that it is an institutional construction that is not easily separated from democratic decision-

\footnotetext{
11 Tóth (2014), pp. 20.

${ }^{12}$ Suksi (1998), p. 170.
} 
making. ${ }^{13}$ Benedikter describes the various forms of government based on the constitutional legal relation between constituent parts of a state. He separates regional territorial autonomy from other forms of power-sharing through the following criteria: Reservations do not have representation within the national parliament of their host country; dependent territories are not part of the motherland or mainland and they mostly represent a different order of separation; an associated statehood includes the possibility to revoke the association at any times (as was the case with Marshall Islands, Palau, or Micronesia for example) while autonomous status does not encompass unilateral secession, and it cannot be revoked unilaterally by the autonomous region; federal arrangements pertain to the whole territory of a given state, while autonomies are created in one or few units only; ${ }^{14}$ other forms of self-government might contain administrative autonomy (regions without legislative competencies such as Corsica) or cultural autonomy (or non-territorial ethnic autonomy). ${ }^{15}$ Hannum et al. assesses the common features of autonomies with regard to their internal institutions and the potential international legal personality of that entity by measuring the degree of independent control over their own affairs. With regard to the first aspect, he finds that the vast majority of autonomous entities have executive as well as legislative powers, some degree of local judicial authority and possible joint responsibility in areas of common concern. Regarding the second aspect there are three primary issues that point out the international legal personality of autonomies: police and security arrangements, land ownership and natural resources, social services, financial and economic issues as well as cultural, religious, and internal minority group concerns. With this analysis Hannum defines the place of autonomies relative to internal and international legal circumstances. ${ }^{16}$

Lastly, turning to territorial autonomy described in legal materials, as mentioned earlier we found that the concept has not yet been explicitly defined in international "hard law". There are some hints, however, in "soft law" instruments, like the Explanatory Memorandum of Resolution 361 (2013) of the Congress of Local and Regional Authorities (CLRA) of the CoE, on Regions and territories with special status in Europe: "Special status entails the legal guarantee of more powers (legislative and/or

\footnotetext{
${ }^{13}$ Hannikainen (1998), pp. 91-93.

${ }^{14}$ See the differences between federalism and autonomy in more detail under chapter 1.4.

${ }^{15}$ Benedikter (2007), p. 22.

${ }^{16}$ Hannum et al (1981), p. 861.
} 
administrative and/or financial), at least quantitatively in terms of legislation, and normally privileged forms of representation and negotiation - often by means of bilateral channels with the state - for specific territorial authorities. Such authorities always enjoy political and administrative autonomy, while formal legislative autonomy depends on the constitutional setting of each country.... As a rule, special status only affects specific territories (regions) of a state where there is no wish or need to introduce a fully-fledged federal system". ${ }^{17}$

Bearing all the above in mind, for the purposes of this dissertation, territorial autonomy connotes a special legal arrangement that grants legislative and executive powers to an administrative unit, whose majority possesses an identity other than that of the majority of the state, to govern their domestic affairs through their own decisionmaking institutions.

National Minority: I use the generally accepted concept, established by Recommendation 1201/1993 of the Council of Europe. Accordingly, the expression "national minority" refers to a group of persons in a state who : a) reside on the territory of that state and are citizens thereof; b) maintain longstanding, firm and lasting ties with that state; c) display distinctive ethnic, cultural, religious or linguistic characteristics; d) are sufficiently representative, although smaller in number than the rest of the population of that state or of a region of that state; e) are motivated by a concern to preserve together that which constitutes their common identity, including their culture, their traditions, their religion or their language.

Nation: While this concept is construed by most academics as a set of common values and/or features producing a "specific sense of solidarity between the members of one group", ${ }^{18}$ no commonly accepted legal definition exist. This was also the conclusion of the Committee on Legal Affairs and Human Rights when the Parliamentary Assembly of the Council of Europe (PACE) called upon them to adopt such a definition. The Committee's report states that while no common conception exists, it is possible to list all the various forms this term is being used in law in present-day Europe. Based on this

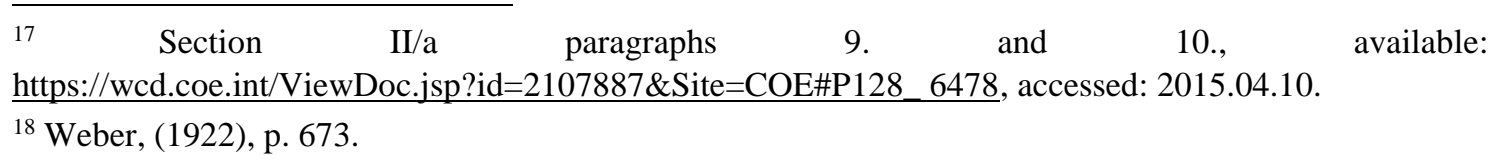


report "the constitution of Romania enshrines clearly the concept of the civic nation, composed of all Romanian citizens". ${ }^{19}$

National state: Nation state or national state refers to a state whose borders coincide with the geographical distribution of a given nation. In other words, this concept was classically defined "in terms of congruence between a territorial state on the one hand and, on the other, a sovereign national community conceived as having a single homogenous culture". ${ }^{20}$ According to Art. 1 (1) of the Romanian Constitution "Romania is a sovereign, independent, unitary and indivisible National State" (Româniaeste stat naţional, suveranşi independent, unitarşiindivizibil). The official English translation makes it clear that the term „national” in the above quoted form was not meant to be a mere adjective to the word "state", but a substantive part of the noun itself. Thus, the concept of ,national state” is the same as „,nation state”.

\section{$1.4 \quad$ Relating concepts}

There are some concepts which are used as substitutes for the term autonomy. Most notably, autonomy and self-government have generally been treated as synonyms, ${ }^{21}$ as were the terms home rule, or self-rule. Devolution describes the process through which a constituent part of a state receives direct competencies of public authority, as opposed to merely exercising public power on behalf of another, superior state agency. ${ }^{22}$

Federalism and autonomy share many similarities, but they also differ in even more aspects. ${ }^{23}$ Except for some cases (like Switzerland or Bosnia-Herzegovina), federalism is seldom based on ethnicity and revolves much more around shared competencies rather than the exclusive ones exercised by an autonomous region. In this sense federalised administrative units exhibit more symmetry in their powers, while a marked asymmetry is more typical of autonomy arrangements. Consequently, autonomy is more flexible than

\footnotetext{
${ }^{19}$ Paragraph 34 of Doc. 10762 of 2005.

${ }^{20}$ Smith (2012), p. xii.

${ }^{21}$ Heintze (1998), pp. 7-8 Hannikainen (1998), p. 79.

${ }^{22}$ Weller et al. (2010), p. 4. For an overview about the difficulties of the concept of devolution, see: Suksi (2011), pp. 114-123.

${ }^{23}$ Some scholars do not even closely connect the two concepts. See: Bernhardt (1981), p. 23.
} 
federalism. ${ }^{24}$ Another relevant difference is that while the federated states or regions are generally involved in policymaking of the central state, autonomous entities rule themselves, and do not necessarily have any special rights regarding the central power. ${ }^{25}$ There are also notable differences from a constitutional legal point of view. The constitution of a classical federation would have a bicameral legislature on the federal level with enumerated powers and residual powers at the sub-state level, while territorial autonomies would have enumerated powers inside a state with a normally unicameral legislature having residual powers. ${ }^{26}$ In federal countries the representation of the constituent states in the national legislature is ensured in some generalized way, while such arrangement would normally not be present in an autonomous territory whose citizens can win representation in the national parliament through the same general electoral mechanism as other citizens of the state. ${ }^{27}$ While the amendment of the constitution of federal states require the consent of several constituent parts, the consent of the institutions of an autonomous region to amend the constitution are not required (at least in so far as the amendment does not affect autonomous competencies). ${ }^{28}$

Lastly, the concept of federacy refers to a specific category of autonomies that were established within unitary states. ${ }^{29}$ According to Stepan et al, a federacy is "a political-administrative unit in an independent unitary state with exclusive power in certain areas, including some legislative power, constitutionally or quasi-constitutionally embedded, that cannot be changed unilaterally and whose inhabitants have full citizenship rights in the otherwise unitary state". ${ }^{30}$ Bolleyer et al substitutes the concept of federacy, with that of regionalized arrangements (as opposed to confederal or federal structures) where "the centre has the final say, notwithstanding the presence of lower tiers of government with legislative powers (that may or may not be constitutionally entrenched)". ${ }^{31}$ Subsidiarity is another important concept mentioned frequently as a

\footnotetext{
${ }^{24}$ Ghai (2013), pp. 16-17.

${ }^{25}$ Benedikter (2007), p. 15.

${ }^{26}$ Suksi (2011), pp. 130-131.

${ }^{27}$ Id. at pp. 403-405.

${ }^{28}$ Watts (2008), pp. 157-170.

${ }^{29}$ From a legal point of view, the term might be misleading in the sense that it insinuates the presence of a voluntary association between an autonomous entity and the unitary state, which is not the case in practice.

${ }^{30}$ Stepan et al (2011), p. 204.

${ }^{31}$ Bolleyer et al (2014), p. 370. States having such asymmetric regionalized arrangements, are often called regionalist- or regionalized states. See e.g.: Benedikter (2007), p. 16.
} 
principle whose aim is to "guarantee a degree of independence for a lower authority in relation to a higher body or for a local authority in relation to central government". ${ }^{32}$

Self-determination: The right of the peoples to self-determination, as set out by Article 1 of ICCPR and ICESCR, is probably the most contentious concept that can be linked to autonomy. Although this study does not engage in a debate about the many question marks surrounding this concept, it cannot fully neglect it either, for at least two reasons. On the one hand, this right has been referred to in conflicts between nationalities and their host countries, ${ }^{33}$ and, on the other, the legal doctrine is constantly evolving and expanding, as the basic division between external self-determination (or remedial secession) and internal self-determination (understood as self-governance of a group that leaves the territorial integrity of a state untouched) is becoming more and more accepted as a customary rule of international law. ${ }^{34}$ As far as academics are concerned, some are sceptic as to how generally the concept of internal self-determination has been accepted, let alone realized within existing states. ${ }^{35}$ Others recognize the existence of such a right, ${ }^{36}$ and there are also scholars who recognize the internal aspect of self-determination, but remind that the term is understood as a right of the whole population of a given state to be free from any external coercion, and not necessarily the right of a minority peoples within that state for greater self-rule. ${ }^{37}$ One can also find international documents underpinning the existence of internal self-determination. In the CLRA`s viewpoint: "In some case, especially when special status is established in order to accommodate ethnocultural minority groups, it is considered to be the most genuine expression of internal self-determination of peoples". ${ }^{38}$ Lastly, case law is also available in the matter. ${ }^{39}$ Para

\footnotetext{
${ }^{32}$ European Parliament (2015), p. 2.

${ }^{33}$ A good example would be that of the Ibarretxe plan, named after Lehendakari (President of the Basque Country) Juan José Ibarretxe, adopted by the Basque Parliament on 30 December 2004, envisaging a free association with the Spanish state based on a plebiscite, and a separate Basque citizenship, all under the right of the Basque peoples to self-determination.

${ }^{34}$ Szalayné argues that within this evolution of the right to self-determination, emphasis, on one hand is being placed on peoples representing a minority in a state rather than peoples under colonial oppression, and, on the other hand on effective democratic self-governance, rather than secession. She also argued that such an evolution of this right is plausible because this is the way through which it can remain an effective part of international law, and avoid being utterly "drained" as a legal instrument. (2003), p. 34.

${ }^{35}$ Hannikainen (1988), p.357, Tomuschat (1992), p. 39.

${ }^{36}$ Rosas (1993), p. 228.

${ }^{37}$ Cassese (1995), p. 346, Hannum (1996), p. 49.

${ }^{38}$ See Section I/6. Of Explanatory Memorandum on CLRA Resolution 361 (2013).

${ }^{39}$ Source: http://scc-csc.lexum.com/scc-csc/scc-csc/en/1643/1/document.do, accessed, 2015.04.22.
} 
126 of Opinion [1998] 2 S.C.R. 217 of the Supreme Court of Canada on the legality of Quebec's secession from Canada concludes that "the recognized sources of international law establish that the right to self-determination of a people is normally fulfilled through internal self-determination - a people's pursuit of its political, economic, social and cultural development within the framework of an existing state. A right to external selfdetermination (which in this case potentially takes the form of the assertion of a right to unilateral secession) arises in only the most extreme of cases and, even then, under carefully defined circumstances". ${ }^{40}$ The autonomy statute of Gagauzia supports this approach as well. Article 1 (4) stipulates that in case of a change of the status of the Republic of Moldova as an independent state, the people of Gagauzia shall have the right of external self-determination. ${ }^{41}$ This also presupposes that Gagauz Yeri otherwise exercises the internal right to self-determination through the institutions of the autonomy arrangement in force.

\subsection{Historical background}

In this brief overview I summarize the history of Hungarian minority affairs within Romania, with an emphasis on autonomy aspirations and their international context. In doing so I have kept in mind the four relevant actors of such a discourse: the given minority communities, the host country, the kin-state, and the international community.

Eastern-Central Europe has always been a buffer zone between the Western parts of Europe and the larger foreign civilization surrounding the continent. ${ }^{42}$ Due to this position, this territory has always been a terrain where major powers have clashed, constantly intersecting the lives of the indigenous population of the area, as well as the political borders they share with each other. Due to the Treaty of Trianon, the Hungarian

\footnotetext{
${ }^{40}$ Declaration 2625 (XXV.) of the General Assembly of the UN on Principles of International Law describes these circumstances and their consequences as follows: subjection of peoples to alien subjugation, domination and exploitation constitutes a violation of the principle and is therefore prohibited. Such forcible action entitles the given peoples to seek and to receive support in accordance with the purposes and principles of the Charter, and at the same time disables the host country to invoke the principle of territorial integrity, as they lack a government that would represent the whole people belonging to the territory without distinction as to race, creed or colour.

41 The ,change” in the status of Moldova refers, above all to the country's possible union with Romania.

${ }^{42}$ Mackinder (1904), p. 435.
} 
Kingdom has lost two thirds of its territory, and population (including, at that time, more than 3,5 million ethnic Hungarians mostly living directly next to the newly established borders) as well as 80 to $100 \%$ of its oil, gas, gold, silver, iron ore, salt and wood supplies. ${ }^{43}$ A Treaty that has still been haunting the collective Hungarian psyche ever since.

On the other hand, if we look at some of the most relevant Treaties concluded by Romania in the XIX. and XX. century, we recurrently find provisions on religious and ethnic equality. This was true of the Treaty of Paris (1856), which granted autonomous status to Wallachia and Moldova within the Ottoman Empire, as well as the Treaty of Berlin (1878) providing international recognition for Romania, and finally, the Treaty of Versailles (1919) that significantly expanded the borders of the country. ${ }^{44}$ These treaties were all contingent on accepting constraints on the country's authority regarding the treatment of minorities. ${ }^{45}$ Moreover, after the First World War, monitoring and enforcement mechanisms were established within the League of Nations to safeguard the implementation of minority rights. Additionally, there was also the Declaration of Alba Iulia/Gyulafehérvár, adopted by the Romanian National Council in 1918 that promised "full national freedom for the co-existing peoples" and that "each people will study, manage and judge in its own language" and that "equal rights and full autonomous religious freedom for all the religions in the State shall be granted". ${ }^{46}$

Contradicting these commitments on minority protection, in practice, Hungarians were deprived of their citizenship even years after the annexation of Transylvania (through Citizenship Law of 1924), their lands and property were subject to confiscation (as of the occupation of Transylvania), the use of the Hungarian language was systematically persecuted (as the Constitution of 1923 did not have any provisions on minority language protection), persons belonging to the Hungarian minority were

\footnotetext{
${ }^{43}$ For a vivid illustration of the economic and social consequences of the Trianon Peace Treaty see the 73 maps in Emich et. al. (1920).

44 This list can be further expanded as Romania made unilateral commitments to implement the documents of the Council of Europe when acceding to the organization in 1993 and has similar commitments as member state of the EU whose founding Treaties and secondary law contain numerous provisions on minority protection.

${ }^{45}$ Krasner (1999), pp. 73-105.

${ }^{46}$ It was this gathering of the Romanian National Council which declared the union of Transylvania with Romania on 1 December, a national holiday in Romania today.
} 
deported to detention camps under the auspices of collective guilt (from 1944) or parallel with this even executed by the paramilitary group, the Мапiu Guards.

The malleable political environment of the late 10 s early 20 s gave birth to numerous plans on the future of Transylvania, coming from Hungarians, Romanians, and Germans (Saxons) alike. These plans included the establishment of a confederation of nationalities, based mainly on the Swiss model; territorial revision, population exchange in order to increase the homogeneity of a given region, the foundation of an independent Transylvanian state, or the establishment of various autonomous arrangements. ${ }^{47}$

During the interwar-period and throughout the course of World War II, Hungary's raison d'état was to regain the territories lost after the First World War. Due to the First and Second Vienna Awards concluded in 1938 and 1940 (see Figure 2), territories in south-eastern Czechoslovakia, north-western Romania and northern Yugoslavia, inhabited mostly by Hungarians, came under Hungarian rule again. These Awards were annulled by the Paris Peace Treaties in 1947, re-establishing the pre-1938 borders.

After WWII both Romania and Hungary were integrated in the "Eastern bloc". Invoking the right of the peoples to self-determination - a principle recognized by the Soviet Union early on, since the Lenin-era - the Romanian communist party was pressured by its Soviet counterpart - or more specifically Gheorghe Gheorghiu-Dej was pressured by Iosif Vissarionovich Stalin - to grant autonomy to the territory populated overwhelmingly by the Hungarian speaking Szekler community. ${ }^{48}$ Articles $19-21$ of the 1952 Constitution were adopted accordingly to establish the Hungarian Autonomous Province. ${ }^{49}$ Parallel with dogmatically respecting the principles of Lenin, the support for Hungarian autonomy was also a bargaining chip in realpolitik, providing Russian leverage over Romania, with whom Russian diplomatic relations were, euphemistically speaking, never cloudless. Being outside the framework of democracy and the rule of law, the Hungarian Autonomous Province cannot be characterized as a political territorial autonomy, as the central state did not actually confer any legislative or executive power

\footnotetext{
${ }^{47}$ Bárdi (2004), pp. 330-331.

${ }^{48}$ For more background information on the subject see: Bottoni (2008).

$4977,32 \%$ (565.510 persons) of the total population (731.387) of the Province was of Hungarian origin according to the data of the Statistical Office, which number rises to $78,71 \%$ if we count the Hungarian speaking population (containing in that case also other minorities, mostly Jews, whose second identity was closer to Hungarian), see: Directia Centrala de Statistica-Directia Regionala de Statistica (1960), pp. 4043.
} 
to the Province under the auspices of decentralization (it did, however, bring forth a more widespread use of the Hungarian language). In fact, it was a tool for furthering centralization by generating direct loyalty among members of the Szekler community towards Moscow. The borders of the Province were first modified only 8 years later, in 24 December 1960, by expanding the western borders with Romanian-majority territories (Ludas, Sármás and Dicső rajons), and at the same time detaching the overwhelmingly Hungarian rajons of Sepsi (85,3\% Hungarian), and Kézdi (91,2\% Hungarian), decreasing the overall proportion of Hungarians from 77,3 to $66,2 \%$ (Miklósné Zakar 2010). ${ }^{50}$ This so called Maros-Hungarian Autonomous Province was then entirely abolished by the administrative reform of $1968^{51}$ establishing the currently existing administrative division of Romania (for border-changes in communist Romania see Figure 3). ${ }^{52}$

The fall of the Iron Curtain and the dissolution of several Eastern-Central European states that followed had a great impact on the international community. Never since the decolonization process did the question of self-determination attract so much attention as in the wake of the Yugoslav Wars. This increased attention came in a sensitive period, as post-communist Romania was facing both internal unrest, and at the same time was seeking to reorganize her international relations, firstly by acceding to the Council of Europe. ${ }^{53}$ The Hungarian minority played an important role in the events of this period, which came into the fore through at least two aspects: Firstly, the whole Romanian political transition was ignited by the harassment of Hungarian clergymen Tőkés László, and secondly, the Black March. The latter refers to events that occurred in the historical capitol of Szeklerland, Marosvásárhely/Târgu-Mureș between 16-21 March. Following a series of protests aimed at achieving education in Hungarian language, the far right, nationalist organization Vatra Romanesca gathered Romanians from surrounding communes and engaged in a fight with protesting Hungarians, resulting in 5 dead (3 Hungarians and 2 Romanians) and almost three hundred wounded. While the some of the

\footnotetext{
${ }^{50}$ Rajons were administrative sub-division of Counties.

${ }^{51}$ In this sense this short-lived Szekler autonomy joined the ranks of other autonomy arrangements that were abolished due to continuous resistance of the central government (e.g.: Chittagong autonomy in Bangladesh under the Chittagong Hill Tracts Accord 1997, South Sudan under the 1971 Addis Abeba Agreement, or the repeal of Eritrea's autonomy under the UN in 1962. Examples mentioned in Ghai (2011), p. 96.).

${ }^{52}$ In fact, Law No. 2 of 1968 on the administrative organization of the territory of the Socialist Republic of Romania is still in force.

${ }^{53}$ Romania joined the Council of Europe on October 7, 1993; NATO on March 29, 2004; and the EU on January 1, 2007.
} 
details of this incident are still vague, one of the common explanations is that members of the communist secret police agency, the Securitate wanted to secure their positions for after the political transition, and fabricated an ethnic strife to underpin the relevance of their presence in a newly formed security agency. ${ }^{54}$

Romania's accession to the Council of Europe and the adoption of Recommendation 1201 in 1993 by the PACE were all favourable developments, placing the question of autonomy in the focal point of the identity building activity of the sole representative organization of the Hungarian community, the Democratic Alliance of Hungarians in Romania. The draft Law on Minorities and Autonomous Communities, adopted in 1993 on the 3rd annual Congress of the DAHR, foresaw the establishment of a three-pillar system: 1) Cultural (or personal) autonomy for members of a minority, 2) the establishment of special statuses for municipalities where a given minority forms the majority, 3) and regional territorial autonomy accruing from the assembly of municipalities with special status. ${ }^{55}$ Senator of DAHR, Csapó József elaborated the 3rd point of this system further by drafting an autonomy statute for Szeklerland. This draft became the fundamental document of the Szekler National Council, founded by Csapó as a representative body - a proto-Parliament - for the Szekler Communes in 2003, with the only purpose to achieve territorial autonomy for Szeklerland. ${ }^{56}$ This document is of particular relevance as the only draft on which the Parliament of Romania has voted on and reacted in an official Opinion (I will discuss this Opinion in detail in the following Chapters).

Meanwhile, Hungary also made attempts to develop an exemplary internal minority policy that would serve as a positive example for the countries of Eastern and Central Europe ${ }^{57}$ For this purpose the country has granted cultural autonomy for all 13

\footnotetext{
${ }^{54}$ See such argument, among others in Kincses (1990).

${ }^{55}$ See: RMDSZ (1993).

${ }^{56}$ It was in the same year (2003) that the ethno-regional party palette started to pluralize, as members of DAHR who were unsatisfied with the party's achievement regarding autonomy and minority rights started to establish their separate organizations. Consequently, there are 5 relevant political organizations advocating the interest of Hungarians in Romania today: DAHR, the Civic Party, The Transylvanian Hungarian People's Party, the Transylvanian Hungarian National Council, and the Szekler National Council.

57 This approach was not a novelty from the Hungarian political elite. As Krasner reminds, domestic support for minority protection in Hungary was present from the end of the First World War, as the country perceived these provisions as a means of protecting their co-ethnics in other countries. See Krasner supra note, p. 95.
} 
recognized minorities of the country, and voiced the relevance of such an approach expressis verbis during the elaboration of a new constitution in 2010, which led to the current Fundamental Law stipulating that "the nationalities of the country form part of the Hungarian political community and are constituent parts of the State" (Preamble, of the Fundamental Law of Hungary). ${ }^{58}$ Additionally, consecutive Hungarian government's implemented various kin-state activities: they established the structure of financial and cultural support through various funds, and created the public television Danube TV (Duna TV) dedicated to broadcast programs to/and about Hungarians living abroad (Antall government: 1990-1994); concluded a series of bilateral Treaties with surrounding countries on good neighbourly relations and cooperation addressing the importance to have a historical reconciliation between Hungary and its neighbours containing also provisions on minority protection (Horn-government: 1994-1998); ${ }^{59}$ provided preferential access to Hungarian public services, and education institutions for kinspeople living abroad through the Status Law (1st Orbán government: 1998-2002); and recently, granted naturalization on preferential terms, including the right to vote on Hungary's parliamentary elections (2nd Orbán government: 2010-2014). ${ }^{60}$

Trying to summarize this brief overview one can state that historical developments on Hungary's side ranged from irredentism (1920 - 1945) and total neglect regarding kinspeople abroad (1945-1990), to active kin-state politics (from 1990 onwards) as a means of preserving Hungarian minority communities living behind the state border, in ever decreasing numbers (See Table 1, and Figures 4 and 5in the Annexes for data and illustration). Historical developments on Romania's side show that Romanian authorities were never really interested in implementing their international commitments in good

\footnotetext{
${ }^{58}$ According to Act LXXVII of 1993 on the Rights of National and Ethnic Minorities, the recognized minorities are: Bulgarians, Greeks, Croatians, Poles, Germans, Armenians, Roma, Romanians, Ruthenians, Serbians, Slovaks, Slovenes and Ukrainians. This Law was replaced in 2011 by Law CLXXIX on the Rights of Nationalities. In this Law, as well as in the Constitution of Hungary, the term "nationality" is being used consistently in order to signal that Hungary recognizes the existence of collective minority rights.

${ }^{59}$ Article 15 contained these provisions, which included: prohibition of discrimination, prohibition of measures that would alter the ethnic proportions, the right to establish and operate minority organizations, the right to take part effectively in decisions-making, the right to use their mother tongue, and the right to preserve their material and architectural memorials and memorial sites constituting their cultural heritage, history and traditions.

${ }^{60}$ Hungary's foreign policy has 3 basic piers which haven't changed much since the Antall- administration: 1.) Involvement in the Euro-Atlantic integration, 2) A peaceful and prosperous partnership with adjacent countries, 3.) and taking responsibility for Hungarians living abroad. Throughout the years, left- wing administrations tended to emphasize the first pier, while right-wing governments stressed the latter one, leaving the EU integration as a common point of consent.
} 
faith and accepted temporary limitations on their sovereignty only to reach other goals in the process: state recognition, territorial gains, or membership in international organizations. While this might downplay the significance of the international community in the eyes of some, it cannot be neglected that the borders of Eastern-Central Europe were in many cases shaped by external powers, and that without international pressure and external motivation, Romania's account regarding minority protection would most likely have been even more dismal. The Treaty of Paris made Romania (or at that time Wallachia, and Moldova) an autonomous entity within the Ottoman Empire, the Treaty of Berlin recognized the newly established state within the international community, while the Treaty of Versailles expanded its boundaries significantly. Paradoxically, the trajectory of Romania's statehood constitutes an example of autonomy being a precursor to secession, and the formation of a new state.

\subsection{What and why}

\subsubsection{Basic features of the Draft Law on the Autonomy of Szeklerland}

Among the eleven some statute drafts that have been crafted by various organizations since the political transition in Romania, the most salient one is that of the Szekler National Council. So far this is the only draft which the Romanian legislature has had a formal vote on, and the only one that has been approved by the local citizens in an informal referendum. The first four sections of the General Provisions of the Draft Law on the Autonomy of Szeklerland adopted by the Szekler National Council (hereinafter DL) resemble the Catalan and Basque statutes in referring to the special identity of the legal subjects of the autonomy. Section 1 (1) begins with stipulating that "in order to express its historical self-identity, to guarantee equal opportunity to its citizens and to safeguard its Hungarian identity, Szeklerland's population will be transformed into a selfgoverning community". The DL foresees the establishment of an autonomous executive power (The Municipal Committee / Önkormányzati Bizottság, hereinafter The Committee) ${ }^{61}$ responsible to the autonomous legislature (The Municipal Council /

${ }^{61}$ DL Section 30-36. 
Önkormányzati Tanács, hereinafter The Council) ${ }^{62}$ whose representatives would be elected by direct and universal suffrage in a free and secret ballot. The legal basis of the autonomy is provided, among others, by Article 117 (3) of the Constitution, allowing for the establishment of autonomous administrative authorities. Pursuant to Art. 73 (3) r) of the Constitution, the Statute would be enacted as an organic law, ${ }^{63}$ the passing of which requires a majority vote of the members of each Chamber of the Romanian Parliament. ${ }^{64}$ Inspired by the Romanian constitutional framework, parallel with the head of the autonomous government, Szeklerland would also have a President, ${ }^{65}$ who is directly elected for a term of four years, and who can assume this position for two terms of office at most. The President represents the region, appoints the head of The Committee, proposes the date of the Council elections, signs and promulgates legislation of The Council (whose acts are subject to the scrutiny of the Constitutional Court of Romania), and if asked by the head of the autonomous government, presides over the meetings of The Committee. With regards to the internal administrative division, the historical Szekler Seats (Szék) would be re-established, having the same basic institutions as the whole of the region (council, committee, president). ${ }^{66}$ The Council of Szeklerland would have exclusive legislative competencies in the following areas: education and culture, mass communication and media, public welfare, roads and transportation, local commercial- and industrial activity, agriculture, forestry, mining and energy production, determining of own municipal system, ownership and management of public property and utilities, levying and collecting own taxes and fees. The autonomous Parliament would have its seat in the historical capitol, Marosvásárhely / Târgu-Mureș in the building that today serves as the seat of the Council of Maros County. ${ }^{67}$ Finally, the annex of the Statute enumerates all 153 municipalities that would be part of an autonomous Szeklerland.

\footnotetext{
${ }^{62} I d$.at Section 19-29.

${ }^{63}$ This is a similarity with the Spanish constitutional system, where Organic acts are those approving the Statutes of Autonomy (as well as those relating to the implementation of fundamental rights and public liberties: Spanish Constitution Section 81).

${ }^{64}$ Art. 76 CR.

${ }^{65} \mathrm{DL}$, supra note Section 37-46.

${ }^{66} I d$. at Section 47-68.

${ }^{67}$ After the adoption of the DL, Maros County, as we know it today, would cease to exist, as only some communes of it would form a part of the autonomous Szeklerland. For an enumeration of these communes, see Appendix No. 1 of the DL.
} 
The drafters of the Statute were largely influenced by provisions of existing European autonomy statutes. Similar to South- Tyrol, the education system would have linguistically parallel organizational structures. Separate Hungarian and Romanian language education institutions would exist from kindergartens to universities. In Hungarian schools the teaching language would be Hungarian and Romanian would be a compulsory taught subject. Hungarian would become an official language of the region together with the Romanian language. ${ }^{68}$ To ensure the effective use of both languages in public administration, a quota would be introduced, similar to the one that exists in South Tyrol. ${ }^{69}$ According to Sections 97 of the DL, the linguistic composition of the employees in the public institutions should reflect the proportion between the linguistic groups of the region, as established by the last official census. The financing of the autonomous competencies would not be totally emancipated from state subsidies, but would nonetheless be mostly ensured through local taxes and fees. Similarly to the Basque fiscal autonomy, all locally generated revenues would be collected and administered by the respective institutions of the autonomous region. ${ }^{70} \mathrm{~A}$ Commissioner appointed by the Romanian government would be the highest representative of the central state in Szeklerland, who also mediates in disputes between the state and the region. ${ }^{71}$ Lastly, the DL provides a regional entrenchment in stipulating that the amendment of the Statute can only be initiated by the autonomous legislature, and that every amendment or the abolishment of the Statute as a whole has to be approved by the local electorate on a referendum. ${ }^{72}$

\subsubsection{Driving forces behind Szekler autonomy aspirations}

Similarly to the case of Tyrol in the Habsburg Monarchy, Szeklerland was a border guard region of the Hungarian Kingdom since the early middle ages. As a military class, Szeklers obtained a special status within the social order of the kingdom, and developed

\footnotetext{
${ }^{68}$ DL, supra note Section 82-96.

69 In South Tyrol this system is often referred to as an "ethnic mirror image"/ "ethnische Spiegelbildlichkeit".

${ }^{70}$ DL, supra note Section 103-116.

${ }^{71} I d$.at Section 119 . While this post was based on the institution of the prefects, it is noteworthy to mention that a similar way of facilitating connections between state and autonomous entity exists in the Åland islands, where a Governor is appointed by the President of Finland (See Section 52 of the Act on Autonomy of Åland).

${ }^{72} I d$.at Section 13 and 125.
} 
their special heraldic symbols and own flag that symbolized this status. ${ }^{73}$ Szeklers were all free men, who were exempted from paying taxes to the King in exchange for their military services. As of the fifteenth century these various rights and liberties were codified in several acts, constituting a separate Szekler law within the legal system of Hungary. ${ }^{74}$ As a consequence of these historical developments, self-governance has been a marked characteristic of the Szekler people. A vital part of their self-identity, which they feel currently deprived of, and which under modern circumstances could be best reestablished in the form of a territorial autonomy. Contrary to the ambitious set of competencies enshrined in the DL, there are numerous deficiencies in the currently existing legal protection afforded to the nationalities of Romania.

\subsubsection{Linguistic and educational issues}

In his report of 19 June 2012, the Committee of Experts (hereinafter, the Committee) of the European Charter for Regional or Minority Languages (hereinafter, the Charter) concluded on the Charter's application in Romania, ${ }^{75}$ that most of the undertakings were not fully implemented. ${ }^{76}$ Out of a total number of 59 undertakings that were relevant from the point of the Hungarian language, only 14 were entirely fulfilled. ${ }^{77} 18$ undertakings were only partly fulfilled, including three instances where the undertaking was considered

\footnotetext{
${ }^{73}$ Szeklers were not the only ones who received such special "autonomous" status. Consecutive Hungarian rulers granted similar territorial self-governing rights in exchange for military service to Saxons, Romanians, Cumans (Kun), Jassic (Jász) people and Serbs from the 13th century, the majority of which remained in existence until the second half of the 19th century. Additionally, Croatia formed a part of Hungary from 1102 till 1918 in the framework of a personal union (meaning that the King of Hungary, by virtue of his office, also became the King of Croatia), and was led by the Bán, who had widespread exclusive competencies, including the right to mint money and to gather an own army without the consent of the king. For more information about the autonomy arrangements that existed in the Hungarian Kingdom see: Kocsis (2013), p. 119.

${ }^{74}$ From the founding of the Hungarian Kingdom in 1 January 1001 till the adoption of the Stalinist constitution in 20 August 1949, Hungary functioned under a common law system, similar to that of the UK.

75 The Language Charter was ratified by Romania through Law No. 282 of 24 October 2007. Available: http://legislatie.just.ro/Public/DetaliiDocument/86674, accessed: 2015.06.23.

76 See Report ECRML (2012) 3, pp. 74-91. Available: https://www.coe.int/t/dg4/education/minlang/Report/EvaluationReports/RomaniaECRML1_en.pdf, accessed: 2015.06.22.

${ }^{77}$ Fulfilled undertakings were: Article 8 - Paragraph 1 a i, b i, c i, e i; Article 9 - Paragraph 3; Article 11 Paragraph 1 b i, c i, Paragraph 2 and 3; Article 12 - Paragraph 1 a, b, d, e, f.
} 
formally fulfilled, but the Committee had concerns about their practical implementation. ${ }^{78}$ One undertaking was not fulfilled, ${ }^{79}$ while the biggest parts of undertakings are those which are not even mentioned in the periodical report provided by the Romanian authorities. ${ }^{80}$ Altogether there were 28 instances where the Committee was not in a position to conclude on the fulfilment of an undertaking, as the periodical report did not contain any specific information on these. The most problematic article of the Charter proved to be Article 10 on the use of language by administrative authorities and public services. Here none of the 13 undertakings were entirely fulfilled. Altogether the Committee found the following deficiencies: Romanian legislation limits the application of several provisions of Article 10 to municipalities where $20 \%$ of the population belongs to a national minority. It was recommended to lower the general thresholds in the field of administrative authorities in order to make them compatible with the Charter. Even in localities which meet this very high $20 \%$ threshold there were severe problems with the implementation of the Charter. ${ }^{81}$ The use of bilingual signs is not always consistent and often depends on local initiatives. At times, the Hungarian inscriptions are erroneous, for example if the Hungarian word for "street" is added to a Romanian name without translating the latter into Hungarian as well (e.g. "Justitiei utca" rather than correct "Bíróság utca"). Furthermore, the corresponding Romanian legislation does not pertain to place-names other than the names of villages/municipalities (for example names of streets or geographical features). Romanian legislation does also not allow Counties to use or adopt place names in a minority language.

Regarding cultural and educational issues, the Committee mentions that in some localities it is not always possible for children from Hungarian-speaking families to

\footnotetext{
${ }^{78}$ Partly fulfilled undertakings were: Article 8 - Paragraph 1 d i,f i, h; Article 9 - Paragraph 1 a ii, b ii , c ii; Article 10 - Paragraph 1 a ii, b, c; Paragraph 2 b, d, g, Paragraph 4 b; Article 11 - Paragraph 1 a ii, d i, g; Article 13 - Paragraph 2 e.

${ }^{79}$ This was Article 9 - Paragraph 3

${ }^{80}$ These were: Article 8 - Paragraph 1 fi, g, i, Paragraph 2; Article 9 - Paragraph 1 a iii, b iii, c iii, d, Paragraph 2; Article 10 - Paragraph 2 c, e, f, Paragraph 4 c, Paragraph 5; Article 11 - Paragraph 1 ei, fi; Article 12 - Paragraph 1 b, c, g, h, Paragraphs 2 and 3; Article 13 - Paragraph 1 a, b, c, Paragraph 2 c, d; Article 14 b.

${ }^{81}$ To illustrate the problems in connection with the implementation of the Charter, the Committee mentions a shadow report where an NGO sent applications in Hungarian to 76 State authorities, local authorities and public service providers located in Mureş/Maros County where 39.3\% of the population belongs to the Hungarian minority. In its letters, the NGO asked for replies in Hungarian and made reference to relevant national laws and Article 10 of the Charter. According to the shadow report, 19 institutions replied bilingually on the substance of the request and 13 in Romanian only, 11 replied in Romanian that the request should be submitted again in the official language, and 33 did not reply at all.
} 
receive Hungarian-medium education from kindergarten to upper secondary school at all the places where Hungarian speakers traditionally reside. There is also no television channel in Hungarian on the national level.

In addition to these observations, there was a deterioration in linguistic rights that occurred after the last monitoring cycle was completed. The most notable of these being the case of the University of Medicine and Pharmacy in Târgu Mureş / Marosvásárhelyi Gyógyszerészeti és Orvostudományi Egyetem (MOGYE). Art. 363 of the Education Law adopted on 5 January, 2011 (2013 Legea Educatiei Nationale Nr. 1 din 5 Ianuarie 2011) enumerates three specific universities that are "multicultural and multilingual". ${ }^{82}$ These are: 1. Babes-Bolyai University in Cluj-Napoca - teaching languages are: Romanian, Hungarian and German; 2. University of Medicine and Pharmacy in Târgu Mureşteaching in Romanian and Hungarian; 3. Arts University in Târgu Mureş- teaching in Romanian and Hungarian. The same article also stipulates that the senates of the respective universities must, within six months from the entry into force of the law, adopt their new university charters pursuant to these provisions. In the first and the third cases the establishment of the minority language department was implemented, in the case of MOGYE, however, the Romanian majority of the Universities Senate denied to follow suit and adopted a Charter that does not foresee the establishment of a Hungarian department. ${ }^{83}$ Given that this conduct manifestly violated the Education Law, the newly elected Prime Minister at the time, Mihai Răzvan Ungureanu, adopted a governmental decree on 13 March, 2012 that established the Hungarian department. As a reaction to this, the opposition, led by social democratic Victor Ponta, lodged a motion of noconfidence on 18 April 2012, claiming that the cabinet had violated the universities autonomy with its decree, that it had been blackmailed to act against Romanian interest, and that a separate Hungarian department would only encourage separatism, and not multiculturalism. ${ }^{84}$ On 27 April, 235 representatives voted in favour of the motion (259 of a total of $460 \mathrm{MPs}$ were present at the vote), and Ungureanu fell from power, only 78 days after his inauguration. The Hungarian department of the Pharmaceutical University

\footnotetext{
${ }^{82}$ Source: http://www.cdep.ro/proiecte/2010/500/80/7/leg_pl587_10.pdf, accessed : 2016.04.11. 83 See the English translation of the Charter here: https://www.umftgm.ro/fileadmin/documente_oficiale/regulamente/UMFTGM-REG-01_EN.pdf, accessed: 2016.04.11.

${ }^{84}$ The motion also mentioned the clientelism of the administration and that it privatizes public property to cronies of the PDL party. See the original text of the motion here: http://legislatie.just.ro/Public/DetaliiDocument/137465, accessed: 2016.04.11.
} 
has still not been established. In view of this background, it is understandable that all of the autonomy statute drafts having been elaborated so far envisage granting official status to the Hungarian language in Szeklerland.

The Experts Committee is not the only body of the Council of Europe that has condemned practices experienced in Romania. The reports of the European Commission against Racism and Intolerance (ECRI) present evidence of a general social climate pervaded by hostile attitudes towards Hungarians. More specifically, ECRI notes that Romanian school textbooks contain stereotypes and prejudice about minority groups. Some textbooks, for example, continue to describe the arrival in Romania of "hordes of barbarian nomads who came from the East to spread terror", and the Hungarians are sometimes depicted as foreigners who occupied the Transylvania region. The history course taught to Romanian pupils is entitled "History of the Romanians" rather than "History of Romania". ${ }^{85}$ ECRI further noted that certain politicians and media have used very harsh discourse targeting Hungarians, which has created tensions between the majority population and this community.

\subsubsection{Religious discrimination}

Another topic that ECRI was particularly keen on was the restitution process of the property that had been confiscated during the communist regime from religious denominations. The process was characterized by ECRI as extremely slow, having many unsolved cases. As an example, they mention that out of the 2522 restitution requests submitted by Hungarian-minority religious institutions, 1103 remained pending. ${ }^{86}$ It was found that the reason for this slowness is that "local authorities have in many cases obstructed the restitution of property, by: not providing information relating to the disputed property; refusing to return certain properties; and challenging before court the decisions of the Special Restitution Commission, the section within the National Authority for Property Restitution responsible for returning religious and national/ethnic

85 See paragraph 81 of Report No. CRI (2006)3, adopted on 24 June 2005. Available: http://hudoc.ecri.coe.int/XMLEcri/ENGLISH/Cycle_03/03_CbC_eng/ROM-CbC-III-2006-3-ENG.pdf, accessed: 2015.06.24.

86 See paragraph 19 of Report No. CRI (2014)19, adopted on 19 March 2014. Available: https://www.coe.int/t/dghl/monitoring/ecri/Country-by-country/Romania/ROM-CbC-IV-2014-019ENG.pdf,accessed: 2015.06 .25 . 
communal property". As regards in particular the return of communal real estate belonging to national/ethnic minorities, between 2006 and May 2011, out of a total of 2000 claims, only 568 were processed ${ }^{87}$ Concerns about the unresolvedness of the restitution question were also expressed during the Universal Periodic Review process of the United Nations Human Rights Committee in 2013. In this case the USA, Italy and Hungary were particularly keen on encouraging Romania to promptly adopt responsive and non-discriminatory legislation for property restitution seekers and to accelerate the resolution of pending property cases). ${ }^{88}$

Additionally, despite the fact that the constitution does not refer to the orthodox church as de jure state-church, the state continues de facto to treat is as such (violating the provisions of Law No. 489/2006 on Religious Freedom and the General Regime of Denominations), and grants them all sorts of concessions other denominations are deprived of (e.g. donation of land property or real-estate). ${ }^{89}$ These concessions are politically relevant, given that minority Hungarians often point out that the Orthodox Church actively contributes to the assimilation policies of the state, among others, by building churches in Szekler communes where the overwhelming majority of the population belongs to western Christian denominations. ${ }^{90}$

\subsubsection{Persecution of symbols}

In its fourth monitoring report, ECRI also discussed one of the most contentious issues: the case of the Szekler flag. ${ }^{91}$ The first regulatory procedure in the case of the Szekler flag occurred in relation to Makfalva / Ghindari (north-west Szeklerland), when the commune decided to place the Szekler flag on the façade of the local council building in December 2009. This event was followed by a police interrogation in January 2010, an investigation of the state prosecution, and another inquiry from the deputy prefect of Maros County, aiming to remove the flag. Even though the deputy prefect was unable to

\footnotetext{
${ }^{87} \mathrm{Id}$. at paragraph 20.

${ }^{88}$ See Report No. A/HRC/23/5, available http://dag.un.org/handle/11176/301681, accessed: 2016.01.27.

${ }^{89}$ For more information, see e. g.: Andreescu (2007), pp. 451-480.

${ }^{90}$ See e. g.: http://erdely.ma/publicisztika.php?id=167050\&cim=nem_a_rendszerben_van_hiba_maga_a_ rendszer_a hiba_reflexio_borboly csaba_irasara, accessed: 2017.01.29.

91 See paragraph 168. of Report No. CRI(2014)19, available: https://www.coe.int/t/dghl/monitoring/ecri/Country-by-country/Romania/ROM-CbC-IV-2014-019ENG.pdf,accessed: 2016.04.12.
} 
mention a law that forbids the use of the Szekler flag, he added that what is not legally prohibited, is not necessarily allowed. The rules applying to this issue (first of all Act No. 75 of 1994) ${ }^{92}$ stipulate that it is mandatory to place the Romanian flag on public buildings, but the flags of other countries can only be displayed together with the Romanian flag and only during official state visits, festivities and international meetings. Accordingly, this regulation contains no orientation point for the use of the Szekler flag. The Judgment that concluded this particular case on 10 August 2010, declared that the Szekler flag is the symbol of a historic community, which does not violate any legislation. ${ }^{93}$ In spite of this judgment, the then prefect of Kovászna County, Codrin Munteanu, turned to the court in order to remove the Szekler flag from the mayor's office of the municipality of Uzon, and later on called upon all mayors of his county to take off the Szekler flags from all of their public offices. As the prefect had put it: "The flag on the mayor's office of Uzon symbolizes a non-existing entity and violates the law in the same way as if someone would place the flag of a football team or a car factory on the town hall". ${ }^{94}$ Dumitru Marinescu, Munteanus' successor, followed suit with these methods when he ordered the Szekler flag to be removed from the Ceremonial Hall in Sepsiszentgyörgy / Sfântu Gheorghe where his inauguration took place on 2 February 2013. Similar incidents occurred in Hargita (the other Szekler County beside Kovászna) where prefect JeanAdrian Andrei called upon the mayors of the county to remove all Szekler flags from their public buildings in an official statement on 11 February 2013.

A new line of argument against the Szekler flag emerged later on, when the police of Târgu Mureş / Marosvásárhely fined the Hungarian National Council of Transylvania to 30.000 RON for hoisting a Szekler flag on their local headquarters in October 2013.

\footnotetext{
${ }^{92}$ The full name of this Act is: Law regarding the display of the Romanian flag, singing the national anthem and the use of insignia containing the Romanian coat of arms by public authority and institutions. LEGE nr.75 din 16 iulie 1994 privind arborarea drapelului României, intonarea imnului naţional şi folosirea sigiliilor cu stema României de către autorităţile şi instituţiile publice Textul actului publicatîn M.Of. nr. 237/26 aug. 1994. Available: http://www.cdep.ro/pls/legis/legis_pck.htp_act text?idt=14530, accessed : 2016.04.11

${ }^{93}$ Besides the Makfalva case, to date there has been only one case where the Judgment came out in favour of hoisting the Szekler-flag on public buildings, namely in the case of Erdöszentgyörgy / Sângeorgiu de Pădure. In this latter case the Prefect of Maros county fined the mayor of Erdöszentgyörgy for 5000 RON (1.112 EUR) on 21 January 2015, for refusing to remove the Szekler and the Hungarian flag from the building that serves as local headquarters of the UDMR party. See: http://www.kronika.ro/erdelyihirek/helyukre-kerulnek-a-zaszlok-erdoszentgyorgyon, accessed: 2017.01.25.

94 See: http://mno.hu/hatarontul/munteanu-figyelmeztetett-ne-tuzzek-ki-a-szekely-zaszlot-1132801, accessed: 2015.06.26.
} 
The court ruled against the fine, but did not contest the initial argument of the police that the Szekler flag was a commercial banner. ${ }^{95}$ This argument later reappeared in August 2014 when the police called upon MEP Tőkés László to remove the Szekler flag from his Central Office in Nagyvárad / Oradea envisaging a penalty of up to 50.000 RON in case he would disobey. ${ }^{96}$ Tökés challenged the fine but the decision of the Court of Bihar County came in favour of the police.

As a response to these developments, the Romanian legislature codified the use of local symbols by way of Law 141/2015 on the display and use of the flags of administrative territorial units. Seemingly, this law provides for the opportunity to recognize the Szekler flag as the flag of a county for example, in practice, however, provisions of the law effectively hinder this process. According to Article 3, in the framework of the new procedure, the flag-model adopted by the county council should be sent to the Ministry of Regional Development and Public Administration first, which asks for the opinion of the National Committee of Heraldry, Genealogy and Sigillography of the Romanian Academy. Based on the consultative opinion of this Committee, the flag will be adopted by way of a Government Decree. These new provisions effectively strip administrative-territorial units from the right to decide on their own flags, and confers this right to the central government which could delay or even deny the approval of the county decision.

The ECRI Report mentions that the processes surrounding the Szekler flag cumulated eventually to the point where the hoisting of the flag on official buildings was banned and fines were imposed on municipalities that disobeyed. ${ }^{97}$ The situation was serious enough for ECRI to recommend that the authorities appease tensions between the majority population and ethnic minorities by applying the principle of equal treatment

\footnotetext{
95 The same approach was present concerning the flag of another historical region of Hungarian majority, the "Partium", Judgement of the Court of Bihar County concluded in case Nr. 284/271/2016 that the flag of Partium was a commercial banner, the hoisting of which constitutes a commercial activity, subject to prior authorization processes. See:http://erdely.ma/autonomia.php?id=205813\&cim=jogerosen_reklamzaszlonak_\%20minositettek _a_partiumi_zaszlot_is, accessed: 2017.02.07.

96 Source: http://index.hu/kulfold/2016/02/01/nem_reklamzaszlo_a_szekely_zaszlo/, accessed: 2016.09.03.

${ }^{97}$ A specific case the ECRI report mentions was that of Csikmadaras, a village where the mayor was fined by the court to $9000 \mathrm{RON}$ (approximately $2000 €$ ) for not removing the flag.
} 
concerning the display and use of national and regional symbols and to remedy any violation thereof.

To illustrate the double standards that take place in the treatment of local/Hungarian v. national/Romanian symbols, ECRI mentions a second case which concerned the wearing of a headband with the national colours of Romania by several pupils in a school in the county of Kovászna on the national day of Hungary (March 15). The teacher of the class asked the pupils to remove the headband and this led to an escalation of protests in various towns and the burning of the Hungarian flag. Further to this incident, a group on Facebook was formed inciting violence against Hungarians. As a response, the authorities carried out an investigation into the conduct of the school and reprimanded the headmaster and dismissed the teacher who had banned the wearing of the symbol. ECRI noted that in this respect there is an inconsistency between the reaction of the authorities in the Szekler case and this latter incident. In the first incident the authorities banned the display of local symbols, whereas in the second incident they safeguarded the right to display Romanian national symbols. ECRI deemed that this incongruence should be remedied in order to ensure that there is no discrimination on grounds of ethnic origin in this field.

What could be added to the above is that it appears to be a willingness from the Romanian authorities to apply double standards and negative discrimination to the detriment of Hungarians on a regional basis, too. On the 4th of June 2016, in the centre of Csíkszereda / Miercurea Ciuc local Hungarian civilians and representatives wanted to re-hoist a Szekler flag that had already been on display for a long time, but was temporarily removed due to renovation works. The local police, however, intervened, confiscated the flag, took the organizer into custody and issued a 10.000 RON fine for him in June 2016. ${ }^{98}$ By contrast, only a few months earlier, on 28 November, 2016 in the centre of Gura Humorului (a small town in north-eastern Romania, inhabited overwhelmingly by ethnic Romanians) the flag of the historical region of Bucovina was

98 See: http://www.szekelyhon.ro/aktualis/csikszek/elkoboztak-a-foteri-szekely-zaszlot-csikszeredaban, accessed: 2017.01.25.).This certainly was not the first similar case that the city of Csikszereda experienced. There were two other incidents, both of which were brought about by an infamous Romanian NGO (Asociația Civicăpentru Demnitateîn Europa / Civic Association for Dignity in Europe) whose leader Dan Tanasă initiated dozens of trials to remove Szekler and Hungarian symbols as well as Hungarian written signs from the facade and the interior of public buildings (see: http://www.kronika.ro/erdelyihirek/abekemenyitetta-dan-tanasa-a-folytatodik-a-persorozat, accessed: 2017.01.25). 
hoisted on the Day of Bucovina, accompanied by police tributes, even though no such administrative unit exists. ${ }^{99}$

Lastly, it is worth mentioning that a similarly restrictive approach applies to singing the Szekler and Hungarian anthems. One of the most memorable examples occurred in December, 2011 when the Romanian ice hockey team - the majority of which consits of Szekler-Hungarian players - played a game against Hungary during the Euro Ice-hockey Challenge in Csikszereda, and the players of the Romanian team sang the Hungarian anthem as well as the Szekler anthem before the game. ${ }^{100}$ Romanian news reports were outraged by what was described as a scandalous and preposterous incident. Some news outlets even went as far to speak of high treason. ${ }^{101}$ Another memorable incident happened in December 2014, when the prefect of Kovászna / Covasna County, fined the Hungarian Civic Party because the Hungarian anthem was sung at an event organized by them. The party turned to the court arguing that it is not prohibited to sing the anthem of another country. The court annulled the fine in the end, but not because the singing of the anthem of another county was considered legal, but of procedural flaws committed by the prefect during the procedure. ${ }^{102}$

\subsubsection{Public administration practices}

Completing the already mentioned organizations with a third body of the $\mathrm{CoE}$, the Advisory Committee of the Framework Convention for the Protection of National Minorities (FCPNM) concluded that certain media outlets report in a manner that strengthens existing negative stereotypes associated with certain minorities (in particular the Hungarians), ${ }^{103}$ and that the number of persons belonging to national minorities who work as public officials is proportionally low (notably Hungarians and Roma). The

99 See a video of the festivity here: https://www.youtube.com/watch?v=tqa9Oi2k_hQ, accessed: 2016.06.07.

100 See video footage of the case here: http://erdely.ma/autonomia.php?id=106649\&cim=himnuszbotrany_miert_enekeltek_a_magyarok_a_mag yar_nemzeti_imat_video, accessed: 2017.01.26.

${ }^{101}$ See references in: http://www.origo.hu/sport/jegkorong/20111218-magyarroman-himnuszbotrany-egycsikszeredai-hokimeccsen.html, 217.01.26.

${ }^{102}$ See case nr. 5901/305/2014.

${ }^{103}$ First opinion on Romania adopted on 6 April 2001 - ACFC/INF/OP/I(2002)001, p. 9. Available: http://www.coe.int/t/dghl/monitoring/minorities/3 FCNMdocs/PDF_1st_OP_Romania_en.pdf, accessed: 2015.06.24. 
Advisory Committee recommended that the Romanian authorities adopt the necessary measures to promote a fair representation of the minorities in the civil service. ${ }^{104}$ There has only been limited dialogue between the authorities and the representatives of minorities that have expressed an interest in the measures taken by the State to protect national minorities, ${ }^{105}$ and therefore in the protection afforded by the Framework Convention (the Committee specifically mentions the Csángó Hungarians). ${ }^{106}$ The Committee specifically mentions the two counties with Szekler majority (Hargita and Kovászna) where inter-ethnic and inter-cultural dialogue remains problematic. ${ }^{107}$ Finally, The Advisory Committee notes with regret that the Draft Law on the Status of National Minorities, ${ }^{108}$ which has been under consideration in various forms since 1995, has still not been adopted and continues to be discussed in Parliament. ${ }^{109}$ As a matter of fact, this Draft Law (renumbered as Draft Law 502/2005 in 2005) has become the longest-debated draft law in the history of post-communist Romania. A legislative process that seems to have no end in sight, as the Draft has already been debated in seven Parliamentary Committees (which is also unprecedented, as most legal documents in the country are debated in two or three committees tops), only to slowly melt off the agenda of the Legislature. According to the official homepage of the parliament, Draft Law 502/2005

\footnotetext{
${ }^{104}$ Id at p. 21 .

105 Paragraph 25. of the Second Opinion on Romania adopted on 24 November 2005 ACFC/OP/II(2005)007.

Available:
} http://www.coe.int/t/dghl/monitoring/minorities/3_FCNMdocs/PDF_2nd_OP_Romania_en.pdf, accessed: 2015.06 .24

106 The Csángó people are an ethnic group of Roman Catholic faith living in the Romanian region of Moldavia (adjacent to Transylvania on the eastern side of the Carpathians), especially in the counties of Bacău and Neamț. According to a report of the Council of Europe, the estimated number of the Csángó population ranges from 260,000 to a couple of thousands (depending on the definition, and based on the fact that in the 2002 census only 4.317 persons declared themselves as Csángós, who were concentrated mostly in the municipalities of Klézse/Cleja, Pusztina/Pustiana, and Lészped/Lespezi) out of which only about 60,000 - 70,000 speak the Csángó dialect. The Csángós speak an archaic form of Hungarian and have ancient traditions and lifestyle as well as a great diversity of indigenous folk art and culture. The official Romanian viewpoint is, however, that the Csángós are in fact "magyarised" Romanians from Transylvania. Consequently, the Romanian authorities do not ensure the teaching of the Hungarian language for Csángós. See: Recommendation 1521 (2001) on Csángó minority culture in Romania, and the explanatory memorandum by Mrs TyttiIsohookana-Asunmaa: Doc. 9078, Report of the Committee on Culture, Science and Education from 4 May 2001: http://assembly.coe.int/nw/xml/XRef/X2H-XrefViewHTML.asp?FileID=9301\&lang=en, accessed: 2015.07.27.

107 Paragraph 92 of the Second Opinion on Romania - ACFC/OP/II(2005)007.

108 The lack of such a legislation means that the rights of minorities are currently scattered in the Romanian legal system in several different sources of law.

${ }^{109}$ Paragraph 38 of the Third opinion on Romania adopted on 21 March 2012 - ACFC/OP/III(2012)001. Available: https://rm.coe.int/CoERMPublicCommonSearchServices/DisplayDCTMContent?documentId= 090000168008c6a3, accessed: 2017.01.29. 
has not been on the parliamentary agenda since 2012 when it was sent back to the Committee for Human Rights, Cults and National Minorities for further analysis. ${ }^{110}$

The third report of the Advisory Committee also makes references to the administrative reform, another process that continues to grow longer and longer. In this issue the Advisory Committee noted that "the proportion of persons identifying themselves with national minorities is likely to diminish in some of the proposed larger units, which may affect the exercise of a number of rights which are conditional on reaching a certain threshold of persons identifying themselves with a national minority and residing within the territorial unit in question. Such a development, in the opinion of the Advisory Committee, might lead to the weakening of the possibilities for persons belonging to the minorities to influence and participate in local affairs." 111 To remedy the problem, The Advisory Committee urged the authorities to ensure that "the rights of persons belonging to national minorities are duly taken into account when planning and implementing the reform of territorial administration in Romania and that there is no negative impact on the right of persons belonging to national minorities to participate effectively in public affairs at local level", ${ }^{112}$ in accordance with the principles enshrined in Article 6 of the Framework Convention.

The issue is also mentioned in the 4th ECRI Monitoring Report, which notes that two issues are at the heart of the growing tensions which have characterized the relations between the majority population and the Hungarian minority. "The first concerns the planned constitutional and administrative reform which aims to reorganize the counties in eight administrative regions. ECRI has been informed that the Hungarian minority fears that this will dilute their representation in the new regions and that these will not coincide with the cultural "borders". The second issue refers to the growing demand from the Covasna and Hargita counties for greater regional autonomy, which has at times been interpreted by the national authorities as a wish to secede from Romania". ${ }^{113}$

It follows from the above-quoted observation of ECRI that interpreting demands for greater self-rule and decentralization as a secessionist threat can only result in immediate vigour from public institutions to any manifestation that points in the direction

\footnotetext{
${ }^{110}$ See: http://www.cdep.ro/pls/proiecte/upl_pck.proiect?idp=6778, accessed: 2017.01.26.

${ }^{111}$ Paragraph 193. of the Third opinion on Romania- ACFC/OP/III(2012)001.

${ }^{112}$ Id. Paragraph 194.

${ }^{113}$ Report No. CRI (2014)19, paragraph 167
} 
of regional autonomy. This approach came to the fore particularly well when the Szekler National Council called upon the 153 municipalities of Szeklerland to adopt proautonomy municipal resolutions. ${ }^{114}$ More specifically, these resolutions stipulated that the Szekler cities and villages wish to be part of a unified Szekler administrative unit in the future, which unit should be called Szeklerland and should be vested with autonomous competencies as set out in an organic law, and that this autonomy should include the official status of the Hungarian language, along with the Romanian language. ${ }^{115}$ Such resolutions were adopted by 62 municipalities, representing 376.271 inhabitants, amounting to $47,08 \%$ of the population of Szeklerland. ${ }^{116}$ Even though these resolutions pertained to a future preference, and did not contain any tasks to be fulfilled by local authorities, the Prefects of Maros, Hargita, and Kovászna counties challenged all resolutions before the Administrative Courts, which annulled all resolutions through Judgments that contained familiar arguments: a) the only administrative units that the constitution recognizes are communes, towns and counties; b) Romanian language can be the only official language of the state.

Lastly, the Congress of Local and Regional Authorities (CLRA) has also condemned some of the institutional practices of Romania. In their Information Report from 2002, CLRA noted that the de jure suspension of the decisions of local authorities challenged by the Prefect before the administrative courts can have the same effect as annulment and can thus, have an adverse effect on the decision-making autonomy of local bodies. Consequently, the provision at issue is contrary to Article 8.3 of the European Charter of Local Self-Government which establishes that the intervention by the controlling authority should be kept in proportion to the importance of the interests which it is intended to protect. ${ }^{117}$ Recommendation 300 (2011) of the Congress notes with concern the lack of transparency in the allocation of financial resources between the

114 See the text of the call here: http://sznt.sic.hu/husic/index.php?option=com content\&view=article\&id=724\%3 Amasfel-szaz-szekely-oenkormanyzatnyilvanitsa-ki-akaratat\&catid=13\%3Akoezlemenyek\&Itemid=18\&lang= fa, accessed: 2017.02.01.

115 About the results of this campaign, SzNC informed: The Parliament and the Government of Romania, the Secretary-general of the CoE, the PACE, the Congress of Local and Regional Authorities, the Committee of Regions, the European Parliament, and the Human Rights Council of the UN.

116 See the full list of these municipalities here:http://www.sznt.sic.hu/husic/index.php?option=com content $\&$ view $=$ article $\&$ id $=752 \% 3$ Aszekely-oenkormanyzatok-az-autonomszekelyfoeldert\&catid=12\%3Afolyamodvanyok-valaszlevelek\&Itemid=16\&lang=fa, accessed: 2017.01.31.

${ }^{117}$ Paragraph 76/a a) of Information Report No. CG/INST (8) 55 rev / 2002. 
central and local levels of government which does not allow either to address the real needs of local authorities or the insufficient consultation with the local authorities in the decision-making process on all questions directly concerning them. ${ }^{118}$

\subsubsection{Criminalization of autonomy aspirations}

The criminalization of the Szekler-Hungarian community and their autonomy aspirations has a robust history in the country, the roots of which go way back to the totalitarian regimes of the XX. century. This is illustrated by a Memorandum from 1982, which was the only samizdat publication of communist Romania called Ellenpontok (Counterpoints). The redaction consisted of Hungarian intellectuals and the memorandum was addressed to the second Madrid follow-up meeting of the Conference on Security and Cooperation in Europe to review compliance with the 1975 Helsinki Accords. The Memorandum points out that: "state powers treat us [the Hungarian community -ed.], especially intellectuals and workers, as if we were the enemies within. Terror on the part of the security forces is the order of the day. If we speak out in defence of our heritage, it is we who are called chauvinistic. We live as second-class citizens in Romania, whose possibilities for career advancement are also limited by the fact that we are Hungarians. We lack any means of self-protection....Thus, our situation is characterized by the denial of not only our individual rights, but our collective rights as well, two sets of rights which are inseparable in our case". ${ }^{119}$

The validity and the continuity of these observations are confirmed by the findings of the annual activity reports of the Romanian Secret Service. Autonomy issues are usually mentioned under the sub-chapter dealing with the protection of the Constitution (Apărarea Constituţiei). Here, the "autonomy-discourse" is depicted as "ethnic radicalism" that strives to "internationalize the anti-Hungarian politics of Bucharest", and

118 Paragraph 5/b, c. Available: https://wcd.coe.int/com.instranet.InstraServlet?command=com.instranet.CmdBlobGet\&InstranetImage=2 550142\&SecMode $=1 \&$ DocId=2147904\&Usage $=2$, accessed: 2015.06 .24 .

119 Source: Beszélő online (1982), I. évfolyam, 5. szám: available: http://beszelo.c3.hu/cikkek/memorandumok-es-programjavaslatok. For the English text of the Memorandum see: http://www.hungarianhistory.com/lib/bors/bors15.htm, accessed: 2016.02.21. 
at the same time aims to "aggressively emphasize Szekler ethno-cultural characteristics". ${ }^{120}$

The most obvious method to criminalize a democratic autonomy movement is to apply double standards to those struggling for it, and label their cause as illegitimate and extremist. In Szeklerland the culmination of this approach can be witnessed with regards to the "Day of the Szekler Freedom" protests (hereinafter DSF). ${ }^{121}$ This event is organized in the historical capital of Szeklerland, Marosvásárhely / Târgu Mureș annually on 10 March ${ }^{122}$ by the Szekler National Council and with the participation of domestic Hungarian political parties as well as foreign politicians and public figures, attracting tens of thousands of people each year. The main goal of the DSF is to demand territorial autonomy for Szeklerland and to protest against the already mentioned administrative reform plans of the government, which in its present format attempts to assimilate the counties with substantial Szekler population into a larger administrative region in which the proportion of Szeklers would drop below $30 \%$ of the population. ${ }^{123}$ Given these contentious goals, various tools have been deployed to hinder the organization of the DSF:

On 10 March, 2014 the Gendarmerie of Maros County issued a fine amounting to 12.000 RON / 2700 EUR for the organizers of the DSF, based on Article 26 a) of Act 60/1991 on the organization of public meetings. This article aims to penalize those who are "organizing and conducting undeclared, unregistered or prohibited public meetings". This has proved to be the main argument against the event and its organizers and has been continuously invoked by the authorities' year after year. The Gendarmerie argued that one would need prior approval from the police to hold any demonstration. On the contrary, the organizers argued that according to the law one only needs to inform the authorities about a demonstration (which they had done), and not ask for their permission,

\footnotetext{
120 Raportul de activitate al ServiciuluiRomân de Informaţiiînanul 2014, p. 7. Available: https://www.sri.ro/fisiere/rapoarte/Raport_SRI_2014.pdf, accessed: 2017.01.31.

121 The case of the DSF proved to be salient enough to reached the sensitivity threshold of US Diplomacy. See the State Secretary's Country Reports on Human Rights Practices for 2015 in Romania: https://www.state.gov/j/drl/rls/hrrpt/humanrightsreport/index.htm?year=2015\&dlid=252891\#wrapper, accessed: 2017.01.26.

${ }^{122}$ Marosvásárhely / Târgu Mureș is the multi-ethnic centre of Maros County, where the deliberative and executive branches of the County are seated. According to the last census, $49,17 \%$ of the city's population is Romanian, $42,84 \%$ is Hungarian, and 7,99\% other.

${ }^{123}$ According to the last census conducted in 2011: 82.9\% of Hargita-, 73.79\% of Kovászna-, and 38.09\% of Maros county was composed of Hungarian/Szeklers.
} 
given that the right to assembly and to free speech are fundamental human rights that are not contingent on the goodwill of the police. Consequently, the organizers filed a lawsuit against the Gendarmerie before the Court of Marosvásárhely / Târgu Mureș, which transferred the case to the Administrative Court. The case is still pending.

In 2015, the Mayor of Marosvásárhely / Târgu Mureș, Dorin Florea decided to simply ban the annual DSF in 2015, claiming that it creates "ethnic unrest" and turns the city into a "conflict zone". ${ }^{124}$ The organizers contested this decision before the court which ruled in favor of the Mayor due to legal technicalities which happens quite often in Romania. ${ }^{125}$ The court's decision did not take into account the actual topic of the contestation, but instead dismissed the case due to procedural reasons, stating that before turning to the court the plaintiffs should have made a prior complaint to the Mayor's Office.

In an attempt to prevent such malicious practices of the authorities, the organizers filed a prior notification, according to the provisions of the law, with the Mayor's Office already on 2 March 2015, announcing that they will hold the DSF in the same usual place both in 2016 and 2017. Even so, the Mayor's Office decided not to acknowledge this notification, and argued instead that the announcement came too early, and should rather be made at a later stage, closer to the date of the actual event. Furthermore, the Mayor's Office argued that organizing the DSF in 2016 will be problematic, given that it falls into election year (!), and that road construction works were being planned for the trail of the event, due to which public security across the city would be constantly changing (even though they were not able to clarify what kind of construction works they were referring to). The organizers turned again to the court, which ruled in favor of them, ${ }^{126}$ concluding that the above-mentioned arguments of the Mayor's Office lacked any kind of legal basis whatsoever to deny the registration of the event, and that the organizers fulfilled all prior notification requirements. Additionally, the judge admonished the Mayor for refusing to acknowledge the announcement of the organizers because with this conduct he deliberately "refused to settle the request of the applicant". ${ }^{127}$

\footnotetext{
124 See e.g.: http://www.evz.ro/marsul-secuilor-naste-tensiuni-inainte-de-organizare.html, accessed, 2016.08.18.

${ }^{125}$ See cases mentioned under Chapter 1.6.2.3.

${ }^{126}$ See Judgement No. 16/2016 from 8 January, 2016.

${ }^{127}$ See p. 6 , last paragraph of Judgment $16 / 2016$.
} 
A week after the DSF of 2016 had been held, the Gendarmerie of Maros County started to issue fines amounting to $61.000 \mathrm{RON} / 13.700$ EUR in 50 cases pursuant to Act 60/1991 for participating in an undeclared, unregistered or prohibited public meeting and 9.800 RON / 2.200 EUR in 34 cases pursuant to Act 61/1991 for noise disturbance (!). This year the Gendarmerie started fining not just the organizers, but also the participants. In some cases, the fined individuals were not even present in Tîrgu Mureș/Marosvásárhely on the day of the demonstration. Given that the event took place without any public disturbance, the organizers believed that the only explanation for penalizing the peaceful exercise of the fundamental right to assembly and free speech was to deter people from participating in the DSF in the future. As a response to these unlawful fines, the organizers lodged a claim for misconduct against the Gendarmerie. The case was transferred to the Office of the Military Prosecutor where it is still pending. Simultaneously, the Szekler National Council encouraged people to turn to the Court of Tîrgu Mureș/Marosvásárhely asking it to annul all fines issued to participants of the DSF.

Not only do the Romanian authorities apply punitive measures against citizens peacefully exercising their fundamental rights to assembly and free speech, they do so based on ethnic and political guidelines. The double standard of the authorities in this regard came to the fore particularly well during the fall of 2015. After the Colectiv nightclub in Bucharest had burned down on 30 October, 2015 leaving 64 dead and more than 180 injured, large masses of people in the Romanian capital spontaneously participated in a series of unregistered demonstrations against corruption. Even though there was no one organizing these demonstrations, no individual was fined or prosecuted as a result of his/her participation in the protests. Similar inequalities can be found in the treatment of various political messages. The far right, neo-Nazi Noua Dreapta (New Right) repeatedly organizes marches in cities inhabited by Hungarians, chanting slogans inciting hatred against Hungarians (for example: "Harghita and Covasna is Romanian land", "Get Hungarians out of the country!", "Romanian language is the only ruler" or that "Romania is for Romanians"). ${ }^{128}$ On 13 February, 2013 Noua Dreapta organized a

\footnotetext{
${ }^{128}$ Sources: Protest in Sepsiszentgyörgy / Sfântu Gheorghe on 1 December, 2014 (the national holiday, commemorating the Romanian National Councils declaration from 1918 claiming that Transylvania is part of Romania: http://www.maszol.ro/index.php/belfold/39447-magyarellenes-roman-unnepsepsiszentgyorgyon, accessed: 2016.08.22. Noua Dreapta also marched several times in Arad on 6 October against Hungarian ,irredentism” (on this day Hungarians commemorate the downfall of the 1848-1849 revolution and the execution of 13 of their generals in Arad by the Habsburg authorities): http://www.nyugatijelen.com/jelenido/a magyar_irredentizmus ellen tuntetnek aradon.php, accessed:
} 
protest in Kolozsvár/Cluj at the Hungarian Consulate General, and parallel with that a protest in Bucharest at the Hungarian Embassy against the use of the Szekler flag on public buildings. Regardless of the fact that the latter protest was a spontaneous, nonregistered event, the police did not intervene or impose any fines afterwards. ${ }^{129}$ Even if the DSF is staged without violence, public disturbance, or incendiary messages, the Romanian authorities initiate numerous proceedings against organizers and since 2016 also against participants. Whereas, on the other hand, marches of the Romanian far-right never encountered any bans, fines or other administrative proceedings, no matter how inflammatory, biased and disrespectful their messages towards Hungarians might have been. Juxtaposing these examples shows that the authorities in Romania apply the right to assembly in a discriminative and selective way to the detriment of persons belonging to the Hungarian community.

The above explained phenomenon indicates that there is a tacit agreement among Romanian authorities that they de facto possess the capacity to effectively ban or allow public protests to be held, especially in the case of politically sensitive events organized by Szeklers/Hungarians. This interpretative framework is diametrically opposed to that of the Council of Europe, which was reflected in several cases of the European Court of Human Rights (hereinafter, the Court), most notably in the case of Bukta and Others v. Hungary. ${ }^{130}$ In this Judgment, adopted on 17 July 2007, the Court reiterated that ,the subjection of public assemblies to a prior-authorization procedure does not normally encroach upon the essence of the right (see Rassemblement Jurassien and Unite Jurassienne v. Switzerland, no. 8191/78, Commission decision of 10 October 1979, Decisions and Reports 17)....". ${ }^{131}$ Furthermore, the Court noted that "where demonstrators do not engage in acts of violence, it is important for the public authorities to show a certain degree of tolerance towards peaceful gatherings if the freedom of

2016.08.22. Noua Dreapta also prefers to march in Marosvásárhely, as they did on 27 March, 2015 demanding the unification of Romania with the Republic of Moldova (Bessarabia): http://www.kozpont.ro/hirek/belfold/marosvasarhelyen-tuentetett-az-uj-jobboldal/, accessed: 2016.08.22.

${ }^{129}$ Source: http://mno.hu/hatarontul/a-szekelyek-nem-magyarok-tuntettek-a-szelsonacionalistak-1138066, accessed: 2016.08.22. See video on the event at: http://ziuadecj.realitatea.net/eveniment/noua-dreapta-apichetat-consulatul-maghiar-din-cluj-fotovideo--106254.html, accessed: 2016.08.22.

${ }^{130}$ Available: www.legislationline.org/documents/id/17932, accessed: 2017.01.29.

${ }^{131} I d$. paragraph 35. 
assembly guaranteed by Article 11 of the Convention is not to be deprived of all substance" (see Oya Ataman v. Turkey, no. 74552/01, §§ 41-42, ECHR 2006-XIV). ${ }^{132}$

When further browsing the case law of the European Court of Human Rights, one can find remarkable similarities between reactions of the Romanian authorities to Szeklers and their political events, and Turkish reactions to Kurdish political claims, or Bulgarian reactions to activities of Macedonian organizations. One notable example was the Sener v. Turkey case. ${ }^{133}$ On 5 September, 1993 the Istanbul State Security Court charged the owner and editor of a weekly review (Haberde Yorumda Gerçek / The Truth of News and Comments)with having disseminated separatist propaganda against the indivisibility of the State, and ordered the seizure of the 23 rd edition of review on that grounds. The article at hand spoke of the extermination of a nation, of genocide, used the term "Kurdistan" and mentioned the right to self-determination of the nations. The Court ruled that Articles 10, 6 (1), and 18 of the ECHR had been violated and reiterated that freedom of expression constitutes one of the essential foundations of a democratic society, as a consequence of which all exceptions and restrictions to this right should be construed strictly and established convincingly. However, the Court reminded that under the provisions of the European Convention on Human Rights (ECHR) there is little scope for "restrictions on political speech or on debate on questions of public interest", and that the "limits of permissible criticism are wider with regard to the government". In this particular case the Istanbul State Security Court presented the argument that referring to a specific region of Turkey as "Kurdistan" in itself constituted "dissemination of propaganda". In this connection the Court noted that Turkish authorities had failed to respect the public's right to be informed of a different perspective on the Kurdish-issue, "irrespective of how unpalatable that perspective may be for them". In this respect, the views of the Romanian authorities with regard to Szeklerland are similar to that of Turkish authorities in connection with Kurdistan. ${ }^{134}$

Analogous pro- and counter arguments have emerged with regard to the freedom of assembly and association in the Socialist Party and Others v. Turkey case, ${ }^{135}$ where the Court reminded that an organization cannot be excluded from the protection of the ECHR

\footnotetext{
${ }^{132}$ Id. paragraph 37.

${ }^{133}$ Source: http://hudoc.echr.coe.int/eng?i=001-58753, accessed: 2017.01.20.

${ }^{134}$ For more detail see Chapter 2.4.

${ }^{135}$ Source: http://hudoc.echr.coe.int/eng?i=001-58172, accessed: 2017.01.20.
} 
irrespective of their political agenda. In this case "exclusion" took the form of dissolution of the Socialist Party by the Constitutional Court on 10 July 1992, for allegedly undermining the territorial integrity of the state through Pro-Kurdish public statements. These statements were in favor of a federalized Turkey where Turks and Kurds would be on an equal footing to the extent that Kurds as a "nation" would have "full and unconditional right to self-determination", including the right to create a separate state should they wish to do so. The Court ruled that Article 11 of the ECHR had been violated and irrespective of Turkish sentiments towards these ideas, one cannot dissolve an association simply because its activities are regarded by the national authorities as ones undermining the constitutional structures of the State.

Similar findings have been made by the Court in the case of Stankov and the United Macedonian Organisation (UMO) Ilinden v. Bulgaria in 2001. ${ }^{136}$ UMO Ilinden's main political goal was not secession or autonomy, but the recognition of the Macedonian minority in Bulgaria and the main activity towards this end was the organization of celebrations to commemorate historical events of importance for Macedonians in Bulgaria. Even so, UMO Ilinden had been refused registration under Bulgarian Lawin 1990, 1998-99 and 2002-04, on the grounds that its statute and programme were directed against the unity of the Bulgarian nation. Even so, the Court concluded that "an automatic reliance on the fact that an organization had been considered anti-constitutional - and refused registration - could not suffice to justify under Article 11(2) of the Convention a practice of systematic bans on the holding of peaceful assemblies. More importantly, from the Szekler point of view, the Court replied to concerns raised by the Bulgarian government that certain leaders of UMO Ilinden harbored separatist views and had a political agenda that included autonomy for the region of Pirin Macedonia or even secession from Bulgaria. Paragraph 97 of the Judgment stated that "the fact that a group of persons calls for autonomy or even requests secession of part of the country's territory...cannot automatically justify a prohibition of its assemblies. Demanding political changes in speeches and demonstrations does not automatically amount to a threat to the country's territorial integrity and national security".

As final remarks to this chapter, it is important to mention two unique attempts to criminalize and discredit Szekler autonomy aspirations. The first example was a draft of

${ }^{136}$ Source: http://hudoc.echr.coe.int/eng?i=001-59689, accessed: 2017.01.20. 
the National Strategy for Order and Public Safety 2015-2020 elaborated by the Ministry of Internal Affairs of Romania. ${ }^{137}$ Among the possible threats to public safety, this draft highlights "manifestations of racism, xenophobia, extremism and other forms of intolerance aimed at achieving autonomy for specific areas / regions based on ethnic criteria." Not only does this paper consider regional autonomy to be a general security threat (such as the deterioration of living standards or the degradation of the education system), it goes further as to characterising autonomy as an extreme manifestation of intolerance, racism and xenophobia. Even though the quoted part was terminated from the text and is not present in the document that was adopted by the Parliament, it demonstrates the general approach of the political elite towards autonomy aspirations.

The second case appeared on December, 2015 when the Romanian Directorate for the Investigation of Organized Crime and Terrorism (Direcția de Investigare a Infracțiunilor de Criminalitate Organizatăși Terorism - DIICOT) arrested two Szeklers (Beke István Attila and Szőcs Zoltán, both members of a right wing NGO called HVIM Hatvannégy Vármegye Ifjúsági Mozgalom / Sixty-four Counties Youth Movement, originally established in Hungary) on the charges that they were planning to explode a home-made bomb on the Romanian national holiday (1 December) in Kézdivásárhely, Szeklerland. ${ }^{138}$

Up to this point no one knows if the charges are valid or not. In any case, if one looks at the indictment, it becomes clear that the DIICOT attempts to expand the accusations to individuals, organizations, even whole communities who have nothing to do with violence, terrorism or extremism, and which never had any personal or institutional connections with the suspects. In order to blur the lines and depict Szekler autonomy aspirations as a terrorist threat, DIICOT uses pictures made at the Day of Szekler Freedom in 2014 to illustrate how extremist are trying to generate anti-Romanian sentiments. Page six of the indictment states the following:

"As you will see, followers of the 'policy of small steps', at events organized by these extremist organizations in Romania, wanted to demonstrate strength, power and discipline while they invited prominent members of far-right movements in Catalonia,

137 Source: http://www.mai.gov.ro/documente/transparenta/SNOSP\%202015-2020\%20.pdf, p. 6.p, accessed: 2015.03 .26

${ }^{138}$ See the indictment here:https://issuu.com/lazarlehel/docs/rechizitoriu_structura_centrala 
Northern Ireland, and the Basque Country to attend and to speak, that is from regions with marked extremist / terrorist problems. The aim in organizing such events is to cultivate, maintain and develop among the Hungarian community of Transylvania ultranationalist and anti-Romanian sentiments, aimed to put strain on relations among members of the two ethnic communities, and consequently damage the climate of peaceful coexistence, and to intimidate and create fear among ethnic Romanians coming from areas where they are a minority relative to ethnic Hungarians."

Irrespective of how the judicial procedure will play out, the quoted parts of the indictment speak volumes about the direction in which the DIICOT aims to push the public discourse and the social climate. Both of these cases represent a proactive attempt of the Romanian deep state to influence public perception and shape public policy decisions to create a hostile environment to autonomy aspirations. ${ }^{139}$

The essence of state attempts to criminalize Szekler autonomy claims was summarized by the President of the Szekler National Council, Izsák Balázs at a Conference in the European Parliament on 19 April 2016 in the following way: Various regulatory institutions of Romania function as political police that implement retribution targeted against those Hungarians who protest against the violation of their rights and who speak out in favour of more autonomy for their community. The practices of the Ceausescu regime`s secret service, the Securitate, are present to date and can be carried out by any of the regulatory bodies of the central state in pursuit of intimidating Hungarians who try to enforce their rights. ${ }^{140}$

\footnotetext{
${ }^{139}$ The term deep state refers to a second order of government behind the publicly elected or constitutional state. An informal network of democratically non-accountable actors who aspire to influence policies of a given national government. While the most obvious example is the military in Turkey or non-accountable agencies, like the NSA in the USA, in conjunction with Romania, the most salient organizations of the deep state are the SRI, the DIICOT, and the DNA (Direcţia Naţională Anticorupţie / National Anticorruption Directorate). See among others: Dale (2015).

${ }^{140}$ Source: http://tokeslaszlo.eu/cikk/a brusszeli_autonomiakonferenciarol, accessed: 2016.04.21.
} 


\section{Chapter 2}

\section{Autonomy and the Constitution of a Nation state}

\subsection{Romanian Constitutional traditions}

For a better understanding of the contemporary constitutional thinking, it is helpful to take a historical overview on Romanian constitutional traditions. The three periods that can be distinguished are the liberal constitutionalism of the XIX century and the early XX century, followed by the communist period, and the current post-communist period.

\subsubsection{Liberal Constitutionalism}

At the beginning of the nineteenth century, most Romanians lived in two separate autonomous entities: Wallachia and Moldavia, both having been under Ottoman suzerainty for centuries. While the Ottoman Empire recognized the political, administrative fiscal and judicial autonomy of these two Principalities, as of the beginning of the Phanariot rule (1711-1821) the Porte started to directly appoint the Princes to both thrones. As a consequence of the Russo-Turkish War (1828-29), the Treaty of Adrianople was concluded on 14 September 1829 giving Russia most of the western shores of the Black Sea along with the estuary of the Danube. Moldavia and Wallachia came under Russian protectorate until the Crimean War, which facilitated freedom of trade for Russia in these territories. To govern the local administration, the Russians adopted a series of Organic Regulations (Regulamentele Organice), which entered into force in 1831-32 and lasted until 1858. They were a mixture of constitutional and administrative regulations inspired by the monarchy enshrined in the French Constitutional Charter of 1814. The holder of sovereignty by divine right was the Prince (Hospodar) who was elected for life from the aristocracy. The parliament (Adunarea Electiva) was composed of members of the nobility and had legislative competencies only to the extent to which the Prince was ready to cede the exercise of power. The regulations did not contain provisions on an independent judiciary and ignored the idea of fundamental rights of citizens, moving the Principalities toward neo-absolutism. The regime of the Organic Regulations ended with the Treaty of Paris from 1856, which settled the Crimean War. As a result, Moldavia and 
Wallachia remained under nominal Ottoman rule but were granted independent constitutions and national assemblies, which were to be monitored by the victorious European powers. These Ad Hoc Assemblies (Ad hoc Divans) were established in 1857 on the basis of popular vote in order to express the wishes of Romanians. The main topic of these Assemblies was the unification of the two principalities in line with the nationalist- ethnocentric type of constitutionalism, which gradually developed since the revolutions of 1848. Even so, the Ad Hoc Assemblies specifically voiced their desire to have a foreign Prince as the ruler. This preference was the result of experiences, as the fourteenth to nineteenth centuries were dominated by intense power struggles between competing local ruling houses and short reigning periods for rulers interrupted by protracted fights among the potential successors. This was a result of historical lack of established rules of succession: while the male-preference principle was clearly present, the rule of primogeniture was absent. Thus, all legitimate and illegitimate sons of deceased rulers fought to accede to the throne. A return to such affairs was seen as a threat to the national unitary state project, therefore the idea of a foreign Prince within hereditary monarchy was considered the best solution. The Paris Convention of 1858 largely neglected these preferences and instead established a constitutional order that was more favourable for the European Great Powers. This entailed the imposition of two separate states led by separate princes with only a limited degree of integration on the level of some secondary institutions. Furthermore, it meant the establishment of French-inspired authoritarian regime led by an elected Romanian prince who disposed over excessive powers and had the jurisdiction of absolute veto right over decisions of the parliament. This constitutional design was also to the detriment of the principles of liberal constitutionalism, such as separation of powers or individual rights and freedoms. The two states attempted to bypass the decision of the Great Powers by electing the same candidate, Alexandru Ioan Cuza in 1859 as Domnitor (ruler) for both countries. On 5 February 1862, the parliaments of the Principality of Moldavia and the Principality of Wallachia formally united to create the Romanian United Principalities. As an admirer of Napoleon III, Cuza started to develop an authoritarian appetite for more power. On 2 May 1864, he initiated the adoption of Developing Statues of the Paris Convention (Statutul Dezvoltător al Convenției de la Paris), which directly transplanted the French constitutional model of the Second Empire. New laws on suffrage were enacted which 
extended the right to vote to the bourgeoisie and to peasants. ${ }^{141}$ Nevertheless, Cuza launched through his governments systematic electoral manipulation. One could thus conclude that the "Romanian unitary state was not founded on parliamentarianism, but against it". ${ }^{142}$ Since the Greater Powers did only recognize the association of Moldova and Wallachia for the duration of Cuza`s reign, the challenge arose in 1866 (after he had been forced to abdicate the throne) how to maintain the status quo afterwards. This reignited the request to elect a foreign Prince, which in the end came from the Swabian Hohenzollern-Sigmaringen House. Carol I of that family was the ruler of Romania from 1866 to 1914 . It was in the same year in 1866 when the first Romanian Constituent Assembly aimed to elaborate the first modern Constitution of Romania, based on massive amounts of direct transplant of provisions from the 1831 Constitution of Belgium. Consequently, the Constitution of 1866 established the Senate as the second chamber of the Parliament, stipulated the irresponsibility of the Monarch. This constitution also took steps to consolidate an "ethnocentric constitutionalism, with strong religious accents", 143 that was concerned with the national unity of ethnic Romanians. These views were reflected in Article 7 that refused to grant citizenship to non-Christians. This regulation in fact made it nearly impossible for Jews to obtain citizenship, while, on the other hand, the Romanian Orthodox Church was elevated to a superior status as the embodiment of the dominant religion of the Romanian state. The institutions, procedural mechanism and principles that were transplanted from the Belgian constitution fell on less fertile soil, given that the great majority of the population at the time (about 80 per cent) was still composed of illiterate peasants. ${ }^{144}$ The small number of intellectuals, on the other hand, studied to a large extent in France, which is one of the main reasons why government meetings were held in French from the eighteen twenties up to the beginning of WW 1, despite the Monarch himself being German. ${ }^{145}$ It was also during this period that Romanians started using the Latin alphabet, as opposed to Cyrillic that was in use until the language reform of 1860. This language reform was the first step in a series of planned language reforms aimed to bring the grammar and the vocabulary of the Romanian

\footnotetext{
${ }^{141}$ Before this new regulation, active and passive suffrage established a census of sex and relatively high wealth, which led to the domination of parliament by great landowners.

${ }^{142}$ Selejan-Gutan (2016), p.10.

${ }^{143} I d$. at p.11.

${ }^{144} I d$. at p. 12.

${ }^{145}$ Id. at p. 31 .
} 
language closer to Romance languages, not the least in pursuit of supporting the politically motivated myth about the origin of the Romanian peoples. ${ }^{146}$ Following successful military campaigns of the Russo-Turkish War of 1877-78, fighting on the Russian side, Romania gained independence from the Ottoman Empire in 1877 and turned into a kingdom four years later in 1881 .

The next important step after independence was to expand the territory of the state with neighbouring regions with Romanian population (Transylvania, Banat, Bukovina, and Bessarabia), which happened because of the Versailles Peace Conference after World War I. This also meant the incorporation of extensive minority communities, Hungarians, Saxons, Russians and Jews. Consequently, in the framework of the Declaration of Alba Iulia, the Romanian National Council, which professed to represent the Romanian community of Hungary, promised to respect the administrative autonomy as well as the cultural and linguistic identity of these communities. These aspects were marginalized in comparison with the aim to consolidate a unitary national state, and the fresh political movements in the newly absorbed part could not bring about a shift in customs of the preWorld War I era. Consequently, the newly adopted constitution of 1923 contained no provisions regarding administrative autonomy or linguistic identity of minorities. In 1938 The "New Royal Constitution" replaced the short- lived Constitution of 1923 and created what is now referred to as the "royal dictatorship" of King Carol II only to be suspended two years later when Marshall Ion Antonescu seized power. As "Leader of the State", Antonescu assumed all legislative and executive power in the framework of the National Legionary State (Statul Național Legionar) from September 6, 1940 to January 23, 1941. It was a right wing, one-party dictatorship based on the German Führer model of the time, dominated by the overtly fascist Iron Guard in conjunction with Prime Minister Ion Antonescu. This jurisdiction did not extend to Northern-Transylvania after that territory came under the rule of Hungary again as a result of the second Vienna Arbitration signed on 30 August 1940.

\footnotetext{
146 According to the theory of Daco-Roman continuity, Romanians descend from the Romanized inhabitants of an eastern province of the Roman Empire (Dacia Traiana), where the native Dacian people mixed with Roman colonists.
} 


\subsubsection{Communist period}

After World War II it was Petru Groza who presided over the consolidation of communist dictatorship as of 6 March 1945. The Senate was dissolved in 1946 and King Michael I was forced to abdicate in 1947 as the country officially became the "People's Republic of Romania". The 1923 Constitution was abrogated and a new interim law was adopted until the adoption of a new Constitution. This law established a Soviet-like collective organ as the bearer of executive power (the Presidium of the Republic). A new unicameral parliament called the Great National Assembly (Marea Adunare Nationala) was elected and entrusted with the task to prepare a new constitution for the new order. This Constitution was adopted in 1952, according to which power lied with working class who exercised it through the Great National Assembly. While a set of freedoms and liberties was enshrined in the text of this constitution, in practice, of course this was the period characterized by confiscation of private property, installation of a single party political system with heavily manipulated elections and pervasive terror of the political police which persecuted, incarcerated and exterminated the "enemies of the state" who were accused of acting against the socialist order. As mentioned before, it was this constitution which established the Hungarian Autonomous Province due to Soviet pressure. Under the auspices of a totalitarian regime this autonomy, however, was largely in lack of true substance regarding decentralization. It also contradicted the ethnocentric mentality of the political elite, which mind-set kept on thriving even during the communist decades. Proletarian internationalism was nowhere to be found in Romanian communism. Thus, the boarders of this autonomous region were changed in 1960 to make it ethnically more Romanian and then 8 years later it was abolished altogether.

The last communist constitution was enacted in 1965. The state organization was similar to that of 1952: "the supreme organ of state power and sole legislator" was the Great National Assembly, and "the supreme organ of the state with permanent activity" was the Council of State. These were complemented in 1974 by the "President of the Republic" which was a formality, given that in practice state power rested with the General Secretary of the Romanian Communist Party, a position that was filled by Nicolae Ceaușescu from 1965 to 1989 after his predecessor Gheorghe Gheorghiu-Dej died. The reign of Ceauşescu can accurately be characterized as one of the most oppressive totalitarian regimes of the XX century. In the framework of an extreme cult of personality, Ceaușescu gave himself titles such as "The Genius of the Carpathians" 
("Geniul din Carpați"). He asserted political persecution through arbitrary arrest, fabricated trials and introduced an atmosphere of fear, paranoia, distrust and terror through the political police, the infamous Securitatea.

\subsubsection{Post-communist period}

As mentioned earlier, the Romanian political transition was ignited by the harassment of Hungarian clergymen Tőkés László in the winter of 1989. New electoral legislation was adopted by Decree-Law No. 92/1990, according to which the first democratic and free elections were held in May 1990. Between 22 December 1989 (the adoption of the revolutionary declaration of the National Salvation Front - NSF) ${ }^{147}$ and 8 December 1991, Romania did not have a constitution. There were no roundtable discussions on the matter; instead, the newly elected legislature established a Drafting Committee having delegates from all parties but being dominated by NSF. The most controversial issues of the drafting procedure were: the form of government, the structure of the parliament, the powers of the President and other institutions of checks and balances. Among the most controversial issues was the request of representatives of the Hungarian community to include autonomy rights within the text. The proposal was rejected as it was seen by the majority of the parties as something that was contrary to the national and unitary character of the state. The Draft Articles were finally sent to the legislature in November 1990 where it was adopted on 21 November with an overwhelming majority of $81 \%$. The constitution was revised in 2003 adding, among others, an important third paragraph to Article 1 that states that: "Romania is a democratic and social state, governed by the rule of law, in which human dignity, the citizens' rights and freedoms, the free development of human personality, justice and political pluralism represent supreme values, in the spirit of the democratic traditions of the Romanian people and the ideals of the Revolution of December 1989, and shall be guaranteed". This means that the complete legal system of the country as of that point should be interpreted in the spirit of democracy, rule of law and fundamental civic liberties.

\footnotetext{
${ }^{147}$ Frontului Salvării Naționale was the name of the ad hoc political umbrella organization that was the governing body of Romania in the first weeks after the Romanian Revolution in 1989, and which subsequently became a political party and won the 1990 election under the leadership of then-President Ion Iliescu. An awkward result from this aspect is that Iliescu himself was a communist who became member of the Central Committee of the Romanian Communist Party in 1965 but fell from grace gradually as Ceaușescu saw an adversary in him.
} 
Overall, we can say that the constitutional history of Romania was characterized by failure to successfully transplant provisions of western European constitutions into the Romanian legal system due to enormous gaps in the social structure, and political culture (e.g. high levels of illiteracy, manipulated elections...). Strong personalization of power, and constant dominance of the executive branch were present as opposed to more parliamentarianism, which was perceived as a threat to the national unitary state and its political stability. Human rights, including minority rights, were only formally consecrated and they "never succeeded to become a true state of mind in the Romanian society". ${ }^{148}$ Constitutional ethnocentrism was an overarching feature, providing a perpetual guideline for various political systems. The lack of democratic constitutional traditions and a track-record of having manipulated and fabricated elections was also a pervasive feature. As Selejan-Gutan summarized the Romanian constitutional history: "interest in limiting political power and in the separation of powers decreased in favour of the idea of building a strong nation state; the interest in rights and freedoms diminished in favour of the idea of national unity; the idea of a political community was replaced by the idea of a community united by blood, language, history and (especially) religion". ${ }^{49}$

\subsubsection{Constitution in force}

Romania is a Republic, with a bicameral legislature that is elected for 4 years by universal, equal, direct, secret and free suffrage. ${ }^{150}$ Bicameralism is symmetrical which means that both the House of Deputies and the Senate have equal powers to discuss and enact laws within their respective sphere of competence, ${ }^{151}$ while none of the Chambers have the jurisdiction to override vetoes or amendments adopted by the other house. The two Chambers are congruent in the sense that they are directly elected, at the same time, use a similar electoral system resulting in similarity of their partisan composition.

The dual executive branch consists of the President directly elected for a term of 5 years, and a Prime Minister with equally long term elected by the House of Deputies.

\footnotetext{
${ }^{148}$ Guțan (2013a), p. 251.

${ }^{149} I d$. at p. 26

${ }^{150}$ Article 62 (1) CR

${ }^{151}$ Enumerated under Article 75 CR
} 
Differences in election often produce political cohabitation, ${ }^{152}$ a phenomenon well known in similar semi-Presidential political systems, most notably in France. In order to deviate from past abuses experienced by an indirectly elected President during Communism, the democratic constitution followed the framework of the 1958 French Constitution in having a directly elected President but with narrower powers than its French counterpart did.

The constitution is on top of the hierarchy of norms followed by three types of state legislation. Parliament can pass constitutional, organic and ordinary laws. ${ }^{153}$ While constitutional laws pertain to the revision of the Constitution, organic laws regulate some of the most relevant institutions of the constitutional fabric such as the functioning of parties, the organization of referendums, state of emergency, rules of local autonomy, or the status of national minorities. ${ }^{154}$ Due to the more salient nature of the fields covered by organic laws, the passing of such legislation requires the majority vote of all the members of each Chamber. ${ }^{155}$ In contrast, the third type of legislation is ordinary laws that are passed by the majority vote of the members present in each Chamber. ${ }^{156}$ Even with this distinction, there are no clear procedural requirements for introducing organic laws to the legislature. Other sources of law contain government ordinances and resolutions of local governments.

The CR adopts the monist approach in incorporating international treaties, which means that Treaties ratified by Parliament shall become part of national law. Article 20 (1) states that Constitutional provisions concerning the citizens' rights and liberties shall be interpreted and enforced in conformity with the Universal Declaration of Human Rights, with the covenants and other treaties Romania is a party to. Furthermore, where any inconsistencies exist between the covenants and treaties on the fundamental human rights Romania is a party to and the national laws, the international regulations shall take precedence unless the Constitution or national laws comprise provisions that are more

\footnotetext{
${ }^{152}$ Cohabitation occurs when the President and the majority of the members of parliament come from opposing parties. The most memorable example of cohabitation in Romania happened in 2012 between Romania's Prime Minister Victor Ponta and President Traian Basescu over the issue of who should represent the country at the European Council. After weeks of clashes, eventually Ponta prevailed.

${ }^{153}$ Article 73 (1) CR

${ }^{154} I d$. Article 73 (3)

${ }^{155}$ Id. Article 76 (1)

${ }^{156}$ Id. Article 76 (2)
} 
favourable. ${ }^{157}$ Consequently, irrespective of the initial intentions of the drafters of the Constitution in 1991, ${ }^{158}$ the Romanian authorities are not free in interpreting the regulations pertaining to fundamental rights and freedoms, as the above provisions put a restraint upon them to align their interpretation with the corresponding international covenants. Article 4 (2) CR makes it even clearer how the constitutional concepts should be interpreted, stating that Romania is the common and indivisible homeland of all its citizens, without any discrimination on account of race, nationality, ethnic origin, language, religion, sex, opinion, political adherence, property or social origin.

Finally, an important aspect of the constitution is the fact that it refers to several forms of autonomy. Article 29 (5) pertains to personal autonomy in the form of freedom of conscience by stipulating that religious cults shall be autonomous from the State and shall enjoy support from it. Article 32 (6) guarantees the functional autonomy of Universities, while Article 120 sets out the principles of local autonomy for territorialadministrative units. Article 117 (3), which we discuss in later chapters, provides a special form of administrative autonomy.

\subsection{Opinion No. 102/2004 - The essential summary of all arguments}

\subsubsection{General objections}

I. The Draft Law aims to create a separate state entity, parallel with the unitary, national Romanian State. ${ }^{159}$

II. As the Draft Law refers to several international legal documents, Opinion Nr. 102 reminds the territorial organization of a state is not subject to community law and falls exclusively under the scope of the authorities of the member states of the Union. It also adds that European organizations do not promote the creation of,

${ }^{157}$ Id. Article 20 (2). This follows the Spanish model, where Section 10 (2) contains similar provisions.

${ }^{158}$ At the constitutional drafting process fears concerning threats to the unity and integrity of the state came to the fore, which triggered the desire to add an "identity mark" to the text of the constitution and emphasize the national character of the state and to carve it in stone for future generations through limitations on constitutional amendment. See Selejan-Gutan (2016), p 41.

${ }^{159}$ Paragraph 1 of Opinion No. 102/2004. 
"asymmetrical, non-uniform or simply just separate, exclusively ethnicity-based intrastate entities, such as autonomous regions", ${ }^{160}$ and that persons belonging to minorities do not have collective rights under international law. ${ }^{161}$

III. Territorial autonomy would result in the positive discrimination of an ethnic minority to the detriment of persons belonging to the majority. ${ }^{162}$ More specifically Art. 94 of the Draft Law (on the use of mother tongue in cultural life) would violate Art. 16 of the Constitution on the principle of equality of rights among citizens. ${ }^{163}$ These provisions also contradict Art. 6 of the Constitution (the right to identity) as well as the provisions of international law. The Opinion specifically quotes Art. 16 and 17 of Resolution 1334/2003 of the Council of Europe, stipulating that "the granting of autonomy must never give a community the impression that local government is a matter for that community alone. Successful autonomy depends on balanced relationships within a state between majorities and minorities, but also between minorities themselves. Autonomous status must always respect the principles of equality and non-discrimination and be based on the territorial integrity and sovereignty of states." Accordingly, to grant special rights to administrative entities that are not recognized by the constitution and are organized exclusively along ethnic lines would violate the principle of equality between citizens of the State.

IV. The Draft Law manifestly contradicts the constitutional order as it foresees the creation of an administrative-territorial institution different from the administrativeterritorial units enshrined in the constitution in terms of both its organization and its special powers. The Opinion cites Art 1 (1), and Art. 2 of the Constitution. The former stipulates that Romania is "a sovereign, independent, unitary and indivisible National State", while the latter one states that "national sovereignty shall reside with the Romanian people" ... and that "no group or person may exercise sovereignty in one's own name". The Opinion argues that the Draft Law violates

\footnotetext{
${ }^{160} I d$. Paragraph 2.

${ }^{161} I d$. Paragraph 3.

${ }^{162}$ Id. Paragraphs 3, and 6.

${ }^{163}$ Id. Paragraph 12.
} 
these provisions and infringes on the sovereignty as well as the unity and indivisibility of the State in the following manner:

a) Unity is understood by the Legislative Council as a single state formation that "assumes a legal order based on a single constitution and a single system of organization, through which the three basic powers are being exercised, and whose population has one single citizenship. This and only this formation is a subject of international law. ${ }^{164}$

b) Indivisibility is described in the sense that Romania "cannot be segmented, nor can it be subject to total or partial division into different legal regimes". 165

c) Sovereignty is violated through the delegation of special - and sometimes exclusive - competencies to the autonomous region whose exercise would eliminate the primacy of state sovereignty within Szeklerland. With the adoption of the Draft Law the population of Romania would no longer belong under one political and legal organizational structure, nor would it have a single state apparatus or a unified state structure, and this territorial division would prejudice the fullness of the sovereignty of the state. ${ }^{166}$ Furthermore, the formation of the autonomous region would make it impossible to implement laws and other legal acts adopted by the Government all over the country. ${ }^{167}$

Altogether territorial autonomy would mean giving powers to an autonomous region that is detached from state sovereignty as that is the nature of territorial autonomy. ${ }^{168}$

V. Art 11 (3) of the Draft Law guarantees the free use of Hungarian national symbols, ${ }^{169}$ which contradicts Art. 12 of the Constitution on the national symbols of Romania. ${ }^{170}$

VI. Art 10 of the Draft Law stipulates that the Hungarian language would become equal to the state language within Szeklerland. This provision violates Art. 13 of the

\footnotetext{
${ }^{164} I d$. Paragraphs 4, and 7.

${ }^{165}$ Id. Paragraph 4

${ }^{166}$ Id. Paragraph 7.

${ }^{167}$ Id. Paragraph 8.

${ }^{168} I d$. Paragraph 5.

${ }^{169}$ For more detail on the topic, see Chapter 1.6.2.3.

${ }^{170}$ Id. Paragraph 9.
} 
Constitution on the official language of Romania. The rights of persons belonging to minorities to use their mother tongue is not the same as granting equal status to a minority language with the official language of the state. ${ }^{171}$

\subsubsection{Procedural objections}

I. According to Art. 3 (3) of the Constitution, the country's territory is organized administratively into communes, towns and counties. Only these levels have administrative and financial competencies, which raises two issues. On the one hand, no such unit as a "region" or a "seat" exists within the current constitutional framework of the country (while both of these being present in the Draft Law). Consequently, no such unit could receive any kind of administrative or fiscal competencies, whatsoever. On the other hand, Szeklerland would have three administrative levels (local, regional, and that of the Seats), whereas the rest of the country would be organized into two of these levels only (local, and county level). This would generate impediments and dysfunctionality with regard to both internal and external cooperation. ${ }^{172}$

II. According to Art. 12 (3) of the Draft Law, the legal basis of the establishment of the autonomous region is Art. 117 (3) of the Constitution which stipulates that autonomous administrative authorities may be established by organic law. In the interpretation of the Legislative Council, however, this Article refers to the central public administration as opposed to the local public administration regulated under Art. 121, which article provides an exhaustive list of local authorities that cannot be further expanded.

III. The Draft Law violates the provisions of Law No. 215 of 2001 on Local Public Administration, according to which "the territorial delimitation of the communes, towns and counties shall be established by law. Any change in their territorial limits may be made only by law and only after prior consultation of the citizens in the respective territorial-administrative units by referendum, to be organised according

${ }^{171} I d$. Paragraph 10.

${ }^{172} I d$. Paragraphs 6, and 15. 
to law". ${ }^{173}$ The Opinion notes that no such referendum was organised prior to the submission of the Draft to the Parliament.

\subsection{Decision No. 80/2014 of the Constitutional Court of Romania rejecting the constitutional amendments proposed by the Special Committee of the Parliament - The Constitutional Court and the recognition of the national ideal}

During the second Ponta administration, the government pushed forward with a constitutional reform package, which included plans on reforming the administrative division of the country by granting administrative competencies to the NUTS II regions. Such an administrative reorganisation would be detrimental for Szeklers, as Szeklerland would be incorporated into a region where the Hungarian speaking community represented less than $30 \%$ of the population. ${ }^{174}$ Trying to react to these developments, the dominant Hungarian party (DAHR), aimed to turn the situation to their advantage by elaborating a draft on amendments to the constitution. These included an additional paragraph (para 3.) to Art. 3 of the constitution. Bearing in mind the example of the South Tyrolean province which blends into a greater region (Trentino - Alto-Adige), this proposed amendment foresaw that "organic laws may recognize traditional areas as administrative subdivisions of regions“. ${ }^{175}$ The same draft also proposed an amendment to Art. 6 of the constitution (on the right to identity) stipulating that "legal representatives of national minorities may establish their own decision-making and executive bodies according to the Statute on National Minorities adopted through legislation, ${ }^{176}$ that are vested with the powers to preserve, develop and express their identity." ${ }^{177}$ Furthermore, this draft foresaw that "decisions of central and local authorities on the preservation, development and expression of ethnic, cultural, linguistic and religious identity are taken after consultation with the organizations of national minorities". ${ }^{178}$ Besides the territorial

\footnotetext{
${ }^{173}$ See articles 20, and 22 of law 215/2001.

${ }^{174}$ Within the current administrative division

${ }^{175}$ CCR Decision 80 (2014), p. 18.

176 This phrasing refers to the need to codify a single statute summarizing all the minority rights, as these are currently dispersed in various laws of the legal system.

177 Supra note, p. 19.

${ }^{178} I d$. at, p. 19.
} 
division and the competencies exercised by them, a third relevant issue was expressed in the government proposal, namely that of the symbols. In pursuit to amend Art. 12 of the constitution (on national symbols), the proposal stated that "national minorities can freely use in public and in private, their own symbols that represent their ethnic, cultural, linguistic and religious identity". ${ }^{179}$

Against these proposals, the Constitutional Court of Romania (CCR) raised familiar objections. On national symbols, the CCR concluded that such amendment could not be placed under Art. 12 of the Constitution as that would entail accepting the idea that the symbols of national minorities are "national symbols", indicating that national minorities have the right to opt for the use of their own symbols as opposed to symbols of the Romanian national state. If such paragraph did have any place in the constitution in the first place, then it would come under Art. 6 on identity, and only on the condition that minority symbols can be used together with symbols of the Romanian national state. On the proposals regarding the right to identity, the CCR announced that the amendment would create collective political autonomy based on ethnic criteria and would thus contradict the principle of equality among citizens and infringe upon the unitary nature of the state, given that ,the essence of the unitary state is the existence of an exclusive set of institutions with political and legal powers (one legislative body, one executive authority, one judicial authority)". ${ }^{180}$ Finally, when it came to the question of the administrative subdivisions, the CCR pronounced something that so far has only been insinuated by the authorities. It is namely that granting administrative competencies to "traditional areas" would not only violate the unitary nature of the state, but they would also "call into question the national character of the Romanian state". ${ }^{181}$ As such, they would also infringe upon Art. 152 (1) of the constitution, stipulating that the "national, independent, unitary and indivisible character of the Romanian State, the republican form of government, territorial integrity, independence of justice, political pluralism and official language shall not be subject to revision". This interpretation of the Constitution clearly depicts Romania as a national state for ethnic Romanians.

\footnotetext{
${ }^{179} I d$. at, p. 20.

${ }^{180} I d$. at, p. 19.

${ }^{181}$ Id. at, p. 18.
} 


\subsection{Political Assertions}

The lodging of the Draft Law on Szeklerland in March 2004 and the referendum campaign that commenced after its rejection ending in February 2008 spanned through two parliamentary terms and three governments, igniting heated reaction from Romanian MPs. In his interpellation from 19 December 2005, right wing (Democratic Party, Partidul Democrat - PD) politician Bogdan Cantaragiu asked the Minister of Public Administration (Vasile Blaga) if his Ministry was prepared to cope with possible separatist activities and actions aimed to undermine the authority of the state, which could take place in the "so called Szeklerland" due to the fact that the Szekler National Council had repeatedly requested to adopt a Statute of Autonomy for this area. In his response, Blaga agrees that the activities of the SzNC affect the climate of public order in the areas inhabited by Szeklers, and that the Ministry of Administration and Internal Affairs will have an eye on such activities and make the necessary legal steps if required. ${ }^{182}$ In 14 February 2007, Gabriel Sandu, MP of the centre-right National Liberal Party (Partidul Naţional Liberal - PNL) demanded answers from the Prime Minister about the measures his administration intends to take against the self-proclaimed referendum on the autonomy of Szeklerland, given that such an illegal referendum can be a real threat to the territorial integrity of the State and can trigger a series of grave problems. ${ }^{183}$ In his response, Călin Popescu-Tăriceanu noted that the municipal resolutions aiming to organize local autonomy-referendums were either annulled by the courts or are in the process of being nullified. The PM also mentioned that several complaints were recorded by the Directorate for Investigating Organized Crime and Terrorism (Direcția de Investigare a Infracțiunilor de Criminalitate Organizatăşi Terrorism - DIICOT) coming from parliamentarians invoking Art. 166 of the Criminal Code ${ }^{184}$ as well Art 19 of Law

\footnotetext{
${ }^{182}$ See: Interpelareanr. 952B/20-12-2005. All Questions and Interpellations cited in this Chapter are available at the homepage of the Chamber of Deputies of Romania: http://www.cdep.ro/pls/parlam/interpelari.home, accessed: 2015.05.09.

${ }^{183}$ See: Interpelareanr. 2386B/14-02-2007.

${ }^{184}$ The mentioned article of the Criminal Code in force at that time stipulated that any illegal or violent action that aimed to change the constitutional order or the national, sovereign, independent, unitary and indivisible character of the Romanian state shall be punished by a term of imprisonment of between 5 and 15 years. This provision has been removed from the Law during its revision in 2009. For this version of the Penal Code, no longer in force, see: http://anp.gov.ro/documents/10180/57727/Codul+Penal+al+Rom\%C3\%A2niei.pdf/7fd6b4fc-a94e-4babbf79-14215deecf08, accessed: 2015.05.09.
} 
no. 51 of 1991 on the National Security of Romania. ${ }^{185}$ While the PM reminded that the initiators of the referendum established no illegal intelligence structures, nor did they engage in any violent actions, he also expresses his disapproval of the idea of autonomy on ethnic grounds as he did many times before. Socialist MP Ion Stan initiated a similar inquiry on 3 March 2008 addressed among others to the Director of the Romanian Intelligence Service (Serviciul Român de Informaţii- SRI). ${ }^{186}$ In his interpellation, Stan asked about the consequences of the "so-called referendum" that was initiated by the "socalled Szekler National Council", which the MP considered an incitement to discrimination and territorial separatism under Art. 30 (7) of the Constitution. Additionally, the Interpellator also demanded a scrutiny of the legality of the financial sources used for "autonomist-separatist activities". In his written response, GeorgeCristian Maoir, Director of SRI made it clear that the Intelligence Service monitors and investigates every activity that affects the rule of law, the constitutional order and the social stability including those relating to the illegal promotion of autonomist-separatist projects based on ethnic criteria. In the cases, Maoir added, in which the obtained information revealed the existence of threats and risks to national security and whose realization would be likely to endanger sovereignty, unity and indivisibility of the Romanian national state, the corresponding authorities were notified so that they could take the necessary measures to prevent or counteract such developments. Regarding the legality of financial resources, the SRI Chief notes that in many cases the representatives of foreign NGOs performing propaganda in favour of autonomist-separatist goals in Romania are acting as individuals and are consequently not subject to Romanian laws on financial control.

Leading politicians made an abundance of like-minded assertions outside the Parliament as well. On 12 August, the then Head of the State Traian Băsescu said during a Summer University in Izvoru Mureșului / Marosfó that he guarantees: “... one will never make an administrative reorganization of the country along ethnic lines. Those who think they can do that confuse us with the Stalinists. Only Stalin organized a Hungarian

\footnotetext{
${ }^{185}$ The initiation, organization, establishment or support of intelligence structures that might affect national security is punishable by imprisonment for a term of 2 to 7 years. For this version of the Act, no longer in force, see: http://legislatie.resurse-pentru-democratie.org/legea/51-1991.php, accessed: 2015.05.09.

${ }^{186}$ See: Interpelare $\mathrm{nr} .3600 \mathrm{~B} / 03-03-2008$.
} 
Autonomous Region". ${ }^{187}$ Next year, on 13 April, 2014 Realitatea TV made an exclusive interview with Băsescu where the President made clear that: "Romania defines herself as a unitary state and anyone who wants autonomy will confront the Romanian constitution and logically also the Romanian state". ${ }^{188}$ On 25 May, 2013 at a Conference on the administrative reform of the country, Crin Antonescu, President of the centre-right PNL Party mentioned that regionalization in Romania will not mean the establishment of "enclaves based on ethnic criteria".

These views of right-wing politicians are unequivocally shared by their left wing counterparts. Regarding the regionalization process, social-democratic Prime Minister Victor Ponta mentioned that a region composed of Covasna, Harghita, and Mures was never on the table, "because that would mean a region along ethnic lines, which does not happen in the EU". ${ }^{189}$ Foreign affairs minister of the Ponta cabinet Bogdan Aurescu reminded after a meeting with his Hungarian counterpart in Budapest that "territorial autonomy based on ethnic criteria is incompatible with the Romanian Constitution, its support is not a part of European norms and is therefore unacceptable". ${ }^{190}$ At a conference that took place on 31 April, 2015 at Babeş-Bolyai University, in Cluj Napoca / Kolozsvár Aurescu also highlighted that: "Romania has developed her own minority protection model, based on the inclusion of minorities into political decision-making, which is not perfect...but is still better than other models". Aurescu also noted that "only the dialogue of the cultures can lead to social development", adding that "cultures which isolate themselves are not able to develop, henceforth territorial autonomy based on ethnic criteria cannot be a good solution within minority protection". ${ }^{191}$ A week later he reasserted these views in an interview with the Romanian news agency, Agerpres, claiming that: "Minority protection in Romanian is guided by interculturality, which is the philosophy of the Framework Convention for the Protection of National Minorities of

187 Source: http://www.mediafax.ro/social/basescu-doar-stalin-a-facut-regiunea-autonoma-maghiara-inromania-nu-se-va-mai-intampla-11247073, accessed: 2016.08.12.

188 Source: http://www.3szek.ro/load/cikk/69492/b\%C3\%84\%C2\%83sescu:_az_autonomia_alkotmany ellenes, accessed: 2016.01.28.

189 Source: http://www.reporterntv.ro/stire/ponta-despre-regionalizare-singura-formula-posibila-e-cu-8regiuni-altfel-deschizi-cutia-pandorei, accessed: 2016.08.12.

${ }^{190}$ Source: http://www.szekelyhon.ro/vilag/ujabb-nem-az-autonomiara, accessed: 2016.02.03

$191 \quad$ Source: $\quad$ http://www.3szek.ro/load/cikk/80249/konferencia_ellentmondasok_kereszttuzeben_ kisebbsegvedelem_kisebbsegek nelkul, accessed: 2016.01.28. 
the Council of Europe. Therefore, we support the merging of cultures and reject separation including autonomy based on ethnic criteria". ${ }^{192}$

Characterizing the maintenance of a minority culture as an undesirable enclave and linking this form of "separation" with undesirable economic developments came again into the fore during the T-529/13, Izsák \& Dabis v. European Commission case. The initial request of the plaintiffs in this case revolved around a European Citizens' Initiative aimed at the reform of the cohesion policy of the EU, which - according to the initiators - should pay special attention to regions that differentiate themselves from the surrounding regions through national, ethnic, cultural, religious or linguistic characteristics (a.k.a. national regions). ${ }^{193}$ The government of Romania joined this lawsuit and argued that the plaintiffs' proposals on the reform of the cohesion policy would have the result that the national, ethnic, cultural, religious or linguistic characteristics of the given national region remain unchanged. As the government pointed out, the proposal would cause the "enclavisation" of these regions leading to detrimental economic developments.

The above-quoted declarations illustrate some of the long-standing characteristics of the Romanian politics. Suspicions towards and full rejection of autonomy in general is present regardless of ideological affiliation or the structure of government coalitions. In practice, the presence or absence of a Hungarian party within the government does not alter this basic characteristic. Romanian politicians tend to challenge the existence of Szeklerland by referring to it only as the "so-called Szeklerland" (aşa-zisului Ţinutul Secuiesc) and/or by putting it between quotation marks ("Tinutul Secuiesc"). Autonomy aspirations are being perceived as an imminent threat to public order, national security and state sovereignty, which is why state authorities need to monitor the organizations engaged in such subversive activities. In addition, territorial autonomy equals selfisolation, the maintenance of ethnic enclaves and would further exacerbate the social and economic backlog witnessed in regions inhabited by minorities. The solution to these non-desirable effects in the "Romanian-model" is interculturality and the merging of cultures, understood as the process of minority assimilation, which in turn contributes to

192 Source: http://www.kronika.ro/belfold/aurescu-veszelyeztetett-a-magyarorszagi-romanok-kulturalisidentitasa, accessed: 2016.01.28.

${ }^{193}$ For more information on this European Citizens' Initiative visit: http://www.nationalregions.eu/, accessed: 216.02.03. 
economic development, provides social mobilization channels and eliminates the root causes of the problem: cultural, linguistic and ethnic diversity.

\subsection{Similar approaches}

Conceiving autonomy as a potential threat to the unity of the state is a thought that is shared by many states across Europe. While the study concentrates on the Romanian case, it is noteworthy to mention some of the similar approaches to deepen the understanding of this phenomenon, in particular the cases of France and Estonia. While there are some countries where governments tend to treat whole minority communities as potential threats due to historical resentment (this is the case with Macedonians and Turks in Greece, and Bulgaria; the Russian minority communities in the Baltic states; Kurds in Turkey, or Hungarians in Slovakia), the two examples presented below are salient by reason of the fact that they represent cases where institutions of central states provided legal arguments against autonomy per se.

As far as France is concerned, an interestingly different approach is present regarding the Overseas Departments and Territories (départements et territoiresd'outremer, colloquially referred to as the DOM-TOM) and Metropolitan France (including not just the mainland but also the surrounding Mediterranean Islands). Within the DOMTOM regions, a large variety of institutional arrangements exists, ${ }^{194}$ out of which the ones possessed by New Caledonia are the widest in scale. ${ }^{195}$ As a result of the 1998 Nouméa Accord, the archipelago gained a special status in 1999 which also included the launch of a public consultation on the independence of New Caledonia from France between 2014 and 2018. A New Caledonian citizenship was established and a gradual transfer of exclusive legislative and executive powers from the French state to New Caledonian institutions commenced. ${ }^{196}$ The constitution of France clarifies that this unique status is

\footnotetext{
${ }^{194}$ See Art. 72 - 75-1 of the French Constitution.

195 See Title XII. of the French Constitution.

${ }^{196}$ Under section 99 of Organic Law No. 99-2009 enacted pursuant to Articles 76 and 77 of the French Constitution, the jurisdiction of New Caledonia pertains to: rules on base and methods of local tax collection, own identity symbols, fundamental principles of labour law, trade union law, social security law, ownership, civil and commercial obligations, rules on access to employment, environmental issues, the electoral system, and the internal municipal system.
} 
based on the principle of the self-determination of peoples and are due to the former colonial status of these territories. ${ }^{197}$ Due to this post-colonial context the comparative value of these examples are largely confined. Nonetheless, they are interesting if one compares this cordial approach to the more vigorously restrictive one exhibited in relation to Metropolitan areas, first and foremost in the case of Corsica. The issue of Corsica has been on the agenda of consecutive governments for decades, the modern phase of which can be traced back to the mid-1960s and which was also characterized by violent actions of the National Liberation Front (FLNC). There were several attempts in various modalities to address the issue. Right-wing administrations (1986-1988; 1993-1995; 1995; 1997) generally applied tactics of repression and 'double diplomacy' negotiating with Corsican political actors while also dealing with separatists and playing one against the other. Left-wing governments (1981-1986; 1988-1993; 1997-2002) sought to propose institutional solutions instead. ${ }^{198}$ There are two relevant rulings of the Constitutional Court of France on Corsica: Decision 91-290 DC of 9 May 1991 and decision 2001-454 of 17 January 2002. The first one is mostly referred to because it declared unconstitutional Section 1 of the Joxe Statute, which stipulated that "the French Republic guarantees to the Corsican people, a living historical and cultural community and part of the French people, the rights to the preservation of its cultural identity and the defence of its economic and social specific interest". The Court declared this provision unconstitutional on several grounds. It infringes upon the unity of the French people (as set out by the Preamble), the indivisibility of the republic (Article 1), and, finally, it violates Article 3 that designates the people as the sole possessor of national sovereignty. The Court argues that the French people regardless of their origin constitute a whole unit incapable of any

197 As the preamble of the French Constitution puts it, by virtue of the principles enshrined in the Declaration of 1789 - confirmed and complemented by the Preamble to the Constitution of 1946, and the rights and duties as defined in the Charter for the Environment of 2004 - and that of the self-determination of peoples, the Republic offers to the overseas territories which have expressed the will to adhere to them new institutions founded on the common ideal of liberty, equality and fraternity and conceived for the purpose of their democratic development.

198 These included: 1.) Law no 82-214 of 2 March 1982, 'Statut de la collectivité territoriale de Corse' that established the Corsican Assembly which was vested with the special power to communicate directly with the government and to be consulted by it on all matters concerning Corsica, even though their opinion was of a non-binding nature. 2.) Law of 13 May 1991 (a.k.a. the 'Joxe Statute') that established a special constitutional status for Corsica (like the overseas territories of Saint-Pierre-et-Miquelon, or Mayotte). 3.) the Matignon Process of 1999-2000 that resulted in a third autonomy statute in January 2001 (granting for the first time the opportunity to teach Corsican language in kindergartens and elementary schools) and constitutional reforms in 2003 that redefined the unitary republican model of the state. See more in Daftary (2004), pp. 24-27, and Henders (2010), 89-123. 
subdivision by statute. The concept of the French peoples perceived in this manner is invoked by the 1789 Declaration of Rights, the Constitution of 1946 as well as the Constitution of 1958 and is therefore a legal concept of constitutional status. The only exemption is the overseas people, which is exactly why the Court has also ruled unconstitutional Section 2 (1) of the Joxe Statute, which stipulated that Corsica constitutes a territorial unit of the Republic within the meaning of Art. 72 of the Constitution on the Territorial communities. The court reminded that Art. 72 and 74 are reserved for overseas territories as opposed to metropolitan France, but noted that devolution of responsibilities that are normally regulated by statue (that is by the central legislature) is not foreseen by Corsica and so cannot be declared unconstitutional. This part argues in favour of the legitimate nature of granting administrative competencies to Corsica as opposed to legislative ones and sets further boundaries to this type of autonomy. The right of the Corsican Assembly to be consulted on bills containing provisions specific to Corsica are not unconstitutional, as they do not restrict the power of the Government to take legislative initiatives. This is not the case with the power to make proposal for legal acts in Corsican matters in a way that obliges the Prime Minister to respond to these proposals, nor is the establishment of a special financial arrangement (regarding, among others, transfer of tax revenues and the allocation of budget resources). Lastly, the Court argued that inserting the Corsican language into school curricula is only constitutional provided that it does not become a compulsory subject. This way of thinking also insinuates that if Corsican was to become a mandatory subject in schools, it would violate the constitutional status of the French language as the only official language of the state.

The second decision came eleven years later in response to the third autonomy statute adopted in January 2001 (for simplicity hereinafter, the 'Matignon' statute). Decision 2001-454 covers mainly the same issues that were brought before the Court in 1991. It reaffirms the reservations regarding the right of Corsica to propose the amendment or adaptation of legal acts and the compulsory education of the Corsican language. Apart from these, the 'Matignon' statute wished to expand the autonomous competencies of Corsica in a very delicate manner. According to the proposed provision: "Where the Corsican Assembly considers that legislative provisions in force or in the process of elaboration as regards the powers of the territorial unit raise difficulties of application related to the specific circumstances of the island, it may ask the Government 
to have the legislature to give it possibility of conducting experiments possibly involving exceptions from the rules in force, for the subsequent adoption by the Parliament of appropriate legislative provisions." Even to this humble proposition did the Court react restrictively, stating that "by giving the legislature, even for a derogatory experiment with limited duration, the possibility of empowering the territorial unit of Corsica to take measures on matters that fall to be regulated by statute, the Act referred has intervened in a matter that is for the Constitution" and which Act would delegate the powers of the legislature in a manner not provided for by the Constitution.

All in all, the French thinking differentiates between overseas people who have the right to self-determination as separate entities from the French people of the mainland. Due to this basic difference, the former can be granted an increased share of public powers, even exclusive legislative and executive ones, while the latter, who is composed of every citoyen regardless of their language or culture, exercises its sovereignty as an indissoluble whole. In theory, this approach would ensure de jure equality among the citizens whether they are members of the majority or a minority. In practice, however, the interpretation of the Constitutional court shows that the majority and its culture enjoy de facto dominance. For the minorities of metropolitan France (including not just Corsicans but Bretons, Basques, Alsatians...etc.) this means that they are only entitled to a narrower sense of self-government which is subject to the better judgment of the majority (as seen with the arguments on the power to propose legislation) and which thus excludes legislative and executive competencies (and includes administrative ones only), limiting also their opportunities of consultation with the centre (allowed only to the extent to which does not bind the actions of the central government in any way) and marginalizing their mother language relative to French (through non-compulsory teaching of the minority language).

In reaction to certain historic events, ${ }^{199}$ as well to Russian policies in the middle of the nineties, ${ }^{200}$ Estonia did not automatically grant citizenship to migrants who originated

\footnotetext{
199 Throughout the course of the Soviet occupation (1940-1991), the demographics of Estonia was dramatically altered as a result of sovietisation policies. Several tens of thousands of Estonians were either killed or deported, while at the same time a large number of Soviet immigrants was sent to Estonia as a result of forced migration policies.

${ }^{200}$ Russia declared that persons of a "post-Soviet" kind who resided outside Russia may apply for Russian dual citizenship.
} 
from the former USSR and required naturalization instead under The Nationality Law, effective as of 1 April 1995. ${ }^{201}$ Because of this policy, even by the end of the decade there were around 150.000 to 200.000 stateless persons present in the country, ${ }^{202}$ as not all residents were able or willing to apply for a citizenship or opt to leave the country instead. Even today there are still about 85.000 people (6,5\% of the population) with undetermined citizenship who are mostly of Russian origin. ${ }^{203}$ Alluding to the discriminative nature of these laws, the overwhelmingly Russian populated Narva City Council adopted a resolution on the 28 June 1993 to organize a local referendum posing the following question: "Do you want Narva to have the status of a national-territorial autonomy within the Republic of Estonia?"204 The City Council of Sillamäe followed suit and adopted a similar resolution on 6 July. The Constitutional Review Chamber of the Supreme Court of Estonia declared the unconstitutionality of these resolutions through decision No. III4/A-2 of 11 August 1993, and III-4/A-3 of 6 September 1993 respectively. In a brief conclusion, the Court raised the substantive legal objection that the constitution does not refer to national-territorial autonomy but only to cultural autonomy as stipulated by Art. 50 of the Constitution. Consequently, the national-territorial form of autonomy is in conflict with the spirit of the constitution. Furthermore, the Court Decision also mentions that the absence of an Act concerning the division of territory of Estonia into administrative units does not constitute a ground for a local government council to determine its own status or to change the Constitutional order of the Republic of Estonia. The Court also alluded to two procedural problems: Due to the fact that the Constitution makes no reference to local referendums, such referenda can only be interpreted as a means to decide on issues that fall within the competence of a local government. In relation to this argument, the Court mentioned that the formation of a national-territorial autonomy falls outside the scope of the local authority's jurisdiction (stipulated under $\S$

\footnotetext{
${ }^{201}$ For more information on the issue see e.g.: Thompson (1998), or Suksi (1999).

${ }^{202}$ Suksi (1999), p. 44

${ }^{203}$ In order to address the problem, the Estonian government adopted it in 1996 when the Estonian Government began to issue special identity documents (known as "alien's passport" or välismaalase pass) to persons of undetermined citizenship who had previously held Soviet passports, thus granting those persons the opportunity to have an official identification within Estonia with which they are also allowed to travel abroad.

${ }^{204}$ According to the last census conducted in 2011, the total population of Estonia was slightly above 1.3 million, $25 \%$ of which had Russian origins (about 325.000 persons) with other ethnic nationalities adding up to 64000 (consisting mostly of Ukrainians, Belarusians, and Finns). For census data visit the homepage of the Statistical Office of Estonia: http://pub.stat.ee/px-web.2001/Dialog/statfile1.asp, accessed: 2015.04.27.
} 
154 (1) of the Constitution), as it represents a national issue to be resolved pursuant to the procedure for deciding national issues. Even given these circumstances, one has to note that Estonia does not rigidly reject every form of autonomy. The Law on Cultural Autonomy for National Minorities adopted on 26 October 1993 ensures non-territorial self-government over cultural affairs as well as education in the minority's mother tongue. 


\section{Chapter 3}

\section{Deconstructing the constitutional barrier}

\subsection{Reactions to Opinion No. 102}

\subsubsection{Reactions to General objections}

I. The territorial autonomy envisaged by the Draft Law would not result in the creation of either a separate or a parallel state entity with the Romanian state. According to Art. 2 of the Draft Law, Szeklerland is an autonomous region having legal personality within Romania. The DL further adds that "the autonomy of the region does not infringe on the territorial integrity and sovereignty of the Romanian state", 205 and that the exercise of autonomous rights have to be "in harmony with the laws of the State". ${ }^{206}$

Parallel competencies are to be found mostly in federal states where one can witness, for example, law enforcement or judicial proceedings on both federal and member state level. Such "duplications" would not accrue from the entry into force of the Draft Law. Although exclusive jurisdiction to adopt legislation on devolved issues is the very essence of autonomy, as defined under the "Concepts" section earlier, the entry into force of the particular set of shared and exclusive competencies present in the DL would not infringe upon the jurisdiction of the central state to exercise the exclusive jurisdiction it would still retain over foreign policy, monetary policy, social security or judicial powers. Decisions of the central state in these issues would continue to be compulsory even for an autonomous Szeklerland.

II. While the territorial, administrative organization of a state is an exclusive competence of the respective national authorities, the regulations of these authorities cannot violate the international commitments of Romania regarding

205 Art. 3DL

${ }^{206}$ Id. at Art. 23. 
minority protection. While the Draft Law is in line with the principle of subsidiarity (a fundamental principle of both European Union law and Romanian law), the plans of the Romanian government regarding the administrative reform of the country disregard this principle by envisaging an administrative distribution in which Szeklerland would be incorporated into a region where the Hungarian speaking community would represent less than $30 \%$ of the population. Such an administrative reform would manifestly violate both the internal laws and the international commitments of Romania as set out by: Art. 6 of the Romanian Constitution; Art. 3 of Law 2/1968 on the administrative organization of the territory of the Socialist Republic of Romania; ${ }^{207}$ Art. 15 (9) of the Treaty between the Republic of Hungary and Romania on Understanding, Cooperation and Good Neighbourly Relations, Art. 2 of the Treaty on the European Union, Art. 21 of the Charter of Fundamental Rights of the European Union, Art. 14 of the European Convention for the Protection of Human Rights and Fundamental Freedoms and Art. 16 of the Framework Convention for the Protection of National Minorities.

On the other hand, however, there are numerous recommendations adopted by European organizations promoting autonomy. These include for example: Recommendation 1201/1993, 1334/2003, 1985/2014 of the PACE; Resolution 361 (2013) of the CLRA; Para 35 of the Document of the Copenhagen Meeting of the Conference on the Human Dimension of the CSCE (5-29 June 1990).

III. According to Kardos, perceiving minority rights as an existential threat or arguing that regional autonomy would infringe upon the rights of the majority citizens or disadvantage them in any way is a form of nationalistic thinking, which proves that the political identity of the majority is based on culture rather than civic equality. ${ }^{208}$ One could add that such arguments would not even exist in the first place if a country truly was a common home to all its citizens regardless of their cultural, ethnic or national origin.

\footnotetext{
${ }^{207}$ Art. 3 of this law states that the county is made up of towns and villages - the basic units of the administrative-territorial organization of the country - depending on the geographical, economic, sociopolitical, ethnic, cultural and traditional ties of the population.

${ }^{208} \operatorname{Kardos}$ (2015), pp. 38- 39.
} 
In pursuit of specifying the principles outlined in Art. 17 of Resolution 1334/2003, rapporteur Andreas Gross lists 9 recommendations to respect when granting an autonomous status. The first two and the last of these recommendations are of particular relevance as they state that autonomous status constitutes a dynamic process that must be based on an agreement negotiated between the parties concerned, and that the devolution of powers to autonomous entities must imperatively protect the rights of minorities living in them. The Draft Law does actually foresee the establishment of such an inherent minority protection scheme. Accordingly, the language of persons belonging to a national- ethnic- linguistic community, whose numbers exceed one hundred in villages, one thousand in towns, five thousand in municipalities and ten thousand in the territory of the Seats will have the same status as the official language of the state. ${ }^{209}$

IV. "Nation state" is not a term of constitutional law, which is why it does not possess a constitutional legal content either. No wonder that it does not appear in constitutions very often. As a matter of fact, Doc. 10762 of the Committee on Legal Affairs and Human Rights on the concept of "nation" shows that while the term 'nation' appears in most of the constitutions, Romania is the only European country whose constitution enshrines the concept of the "nation state". ${ }^{210}$ The same report concludes that "the constitution of Romania enshrines clearly the concept of the civic nation, composed of all Romanian citizens", without any discrimination on account of race, nationality, ethnic origin, language, religion, sex, opinion, political adherence, property, or social origin as set out by Art. 4 (2) CR. Bearing in mind that the fundamental principle of equality and non-discrimination is a peremptory norm (jus cogens) of international law, from which no derogation is permitted, the

\footnotetext{
${ }^{209}$ Art. 10 (3) DL.

${ }^{210}$ In 2003, the Parliamentary Assembly of the Council of Europe (PACE) debated the question of preferential treatment of national minorities by their kin-states in the light of the Hungarian law of 19 June 2001 concerning Hungarians living in neighbouring countries. Among other provisions, this law has defined the concept of "nation" in its preamble. It was not until this debate that the Assembly had realized that to date there had been "no common European legal definition of the concept of 'nation'" (quote from Resolution 1335/2003 adopted after the mentioned debate). Consequently, the Assembly called on the Committee on Legal Affairs and Human Rights to analyse the various forms in which the concept of 'nation' is being interpreted in the constitutions of $\mathrm{CoE}$ member states in order to clarify this so often used terminology. The results are shown in Doc. 10762, and the Recommendation adopted by the Assembly accordingly (Recommendation 1735 (2006) The concept of "nation").
} 
national character of the Romanian state cannot mean that Romania is the national state of ethnic Romanians. It cannot mean that citizens of the titular nation enjoy more rights than citizens possessing different national identities.

a) Unity remains intact. No separate constitutional order would come into being. The autonomous region would be entrenched in the Romanian legal system based on Art. 117 (3) CR, and the Constitution of the country would remain the highest legal norm for an autonomous Szeklerland. It is exactly for this reason that the DL stipulates that in case the legal acts of the autonomous authorities contradict the constitution, the Constitutional Court shall annul them. ${ }^{211}$ Additionally, single citizenship is not a prerequisite of unitary statehood. Several EU states grant dual citizenships and Romania in particular has an extensive legal regime in this regard preferring Romanian kinspeople living behind the state border, mostly in Moldova. Not only does autonomy not threaten the unity, it is on the contrary, an instrument to strengthen the integrity of the state. As Paragraph I/5 of the Explanatory Memorandum of CLRA on Resolution 361 (2013) states: "Special status arrangements for sub-national units not only are consistent with the overarching public international law principle of territorial integrity of states: they also help preserve such integrity by addressing specific claims without challenging the unity of the state". ${ }^{212}$ Similarly, the General Assembly of the United Nations holds that „the promotion and protection of the rights of minorities contribute to the political and social stability of the States in which minorities live and contribute to the strengthening of friendship and cooperation among peoples and States". 213

There is also an overarching academic consensus that autonomy strengthens the unity of a state instead of weakening it. Wolff considers territorial self-governance arrangements as a tool of statecraft and a mechanism of conflict management in divided societies - specifically when compact ethnic groups make demands for self-determination - that provide "institutional solutions that allow the different segments of diverse societies to realize their

${ }^{211}$ Art. 120 DL.

212 Available: https://wcd.coe.int/ViewDoc.jsp?id=2107887\&Site=COE\#P128_6478, accessed: 2015.07.16.

${ }^{213}$ Paragraph II/3 of the Commentary of the Working Group on Minorities to the UN Declaration on the rights of Persons Belonging to National or Ethnic, Religious and Linguistic Minorities, available: http://www.ohchr.org/Documents/Events/Minority2012/G0513385_en.pdf, accessed: 2015.07.16. 
aspirations for self-determination while simultaneously preserving the overall social and territorial integrity of existing states". ${ }^{214}$ Akermark notes, that in essence autonomy is a security arrangement, in the sense that it „helps to fit the idea of a unitary state in the multiplicity of the nation and vice versa to fit the factual and inevitable multiplicity of the nation into the idea of a unitary state". Parallel with this, autonomy consolidates not only territorial integrity but also the democratic political system of states due to the ,participatory paradigm” thereof. ${ }^{215}$ Comparing secessionist movements in Canada, Spain, and the UK, Montserrat concludes that if devolution is founded upon mutual trust, recognition and a sound financial arrangement, then it stands as an antidote against secession for the following reasons: 1) The creation of devolved institutions contributes to the dynamism of civil society by reallocating resources of decision-making and by promoting regional businesses as well as the preservation of regional cultural heritage. 2) Devolution tends to foster a sense of common regional identity where it did not previously exist and strengthen it where a pre-existing sense of identity was already in place (while not excluding the possibility of an overall national identity). 3) A substantial degree of devolution when accompanied by sufficient - or even moderately generous - resources automatically raise the profile of regional political elites, which elites in turn will be reluctant to make a "radical move of unpredictable consequences towards independence". 4) Devolution tends to strengthen democracy through introducing more subsidiarity in public policy decisionmaking. ${ }^{216}$

In fact, even in cases where an autonomous region has seceded from its host country, ${ }^{217}$ it is quite difficult, if not impossible, to argue that the autonomous arrangement was to blame for that result. In practical terms, it is also important that secession is an option for border regions, while Szeklerland lies in the heart of

\footnotetext{
214 Wolff (2013), p. 7.

215 Åkermark (2013), p. 24.

${ }^{216}$ Montserrat (2006), pp.70-73.

${ }^{217}$ See the Caucasian examples in Cornell (2002) where the geographic proximity to Russia and Russian aspirations in the region are more likely to be behind the results seen among others in Abkhazia or South Osetia. One could add the Crimean-peninsula to this list.
} 
Romania and does not have any secessionist parties such as the ones in Flanders, Scotland or Catalonia.

b) According to paragraph 12 of Resolution 1334 (2003) of the Council of Europe: „Indivisibility must not be confused with the concept of the unitary state, and the indivisibility of the state is thus compatible with autonomy, regionalism and federalism." The term itself is primarily a signpost for external forces, mediating the message that the territory of the country should remain intact, and that borders should be respected. Devolving more competencies from the centre to the local authorities cannot be understood as segmenting the country into a patchwork of different legal regimes. The same conclusion was reached by rapporteurs of the Congress of Local and Regional Authorities (Jean-Claude Frecon and Lambert van Nistelrooij), when the question of the administrative reform first reached their agenda in 2002. This report noted that there is no constitutional provision in Romania whatsoever that prohibits considerable devolution of state powers to the counties. ${ }^{218}$

c) Sovereignty would not cease to exist, it would simply be exercised through a democratically elected body other than the Parliament in Bucharest. According to Art 2 (1) of the Constitution, sovereignty lies not in the state but in the citizens of the state, who shall exercise this sovereignty by means of their representative bodies as well as by referendum. In democratic polities, sovereignty is not a zero sum game, as it can be shared, devolved or delegated. Furthermore, as Krasner noted, sovereignty in issues regarding minorities have never been an exclusive jurisdiction of the states. ${ }^{219}$ In this point the diametrically opposing views of the majority and the minority come to the fore. While the Szekler Draft Law presents a bottom-up process, presupposing the voluntary consent of the local citizens in establishing the autonomy arrangement, the majoritarian scenario is of a hierarchical top-down nature, in which popular sovereignty is being confusingly supplemented with state sovereignty.

${ }^{218}$ See paragraph 83 of Information Report No. CG/INST (8) 55 rev / 2002 on Local and Regional Democracy in Romania. Available: https://wcd.coe.int/ViewDoc.jsp?id=888817\&Site=Congress, accessed: 201506.23.

${ }^{219}$ Krasner supra note, pp. 220-239. 
V. Given the poorly phrased or absent legislation on the use of symbols, the antagony between minority and majority views on the use of symbols continues to reopen the political discourse to interpretations on what can be considered lawful conduct. While there is a scholarly debate whether or not the possibility of an open legal system and the absence of law (non liquet) can be ruled out, ${ }^{220}$ as opposed to conceptualizing a universal, and, by extension, closed legal order where the negative law is an inherent part of the legal system, ${ }^{221}$ the concept of "residual principles" is used and commonly referred to in legal practice and legal theory as well. Stone even notes that most legal orders lay down some kind of residual principle, "the effect of which is to occupy the space which would otherwise be devoid of law". 222 One of the most well-known of these is the "residual negative principle", which refers to the idea that everything that is not legally prohibited is legally permitted. This idea stems from the understanding that certain areas of life that are not positively regulated by law are not devoid of law but rather regulated in a residual or negative manner by precluding legal effects in those specific areas. Consequently, in the absence of a norm limiting specific behaviours, the legal system is neutral as to the legal consequences, which grants citizens the freedom to exercise activities of their choice within that framework. The opportunity to think and act with this principle in mind is available for Romanian authorities at all times. The application of the residual negative principle would result in an analogous effect concerning particular cases (like the case of the Szekler flag) that the arguments of this dissertation intends to achieve regarding the general case of Szekler autonomy: A "simple" change in the mind-set can remove an unnecessary and unjustified obstacle to a legitimate minority claim without having to resort to any amendments in the legal system.

VI. Similarly, to views on the exclusivity of sovereignty, a zero sum mentality was traceable in the case of linguistic issues. Even though the DL only suggested recognizing Hungarian as a regional-official language in addition to the Romanian language, the Legislative Council thought that in a unified state there could only be

\footnotetext{
${ }^{220}$ Lauterpacht (1958), pp. 196-221.

${ }^{221}$ Radbruch (1956), p. 298

${ }^{222}$ Stone (1964), pp. 188-192
} 
one official language. If regionalized power sharing is the "autonomist" answer to exclusive central state sovereignty, then multilingualism and linguistic equality is the reply to cultural monochromaticity. The official status of Hungarian would not violate any legislations in force; on the contrary, one could find numerous examples where multilingualism contributed to social peace and mutual understanding among different cultures. Such positive examples include, above all, the linguistic quotas of South Tyrol or the official status of the Swedish language in Finland. The latter examples show particularly well the influence of political culture on law and the interpretation of legislation. Finland is an equally "young" state (even younger than Romania) which - due to its geographic position- had its fair share of foreign occupations (just as Romania). The Swedish community is equally large relative to Finns just like Hungarians relative to Romanians (about 6-7\% of the total population) and their distribution within the country is similar (having in both cases significant areas where they represent the majority). The constitutional design has or had similarities, as both countries are unitary states, led by a semi-presidential form of government (though Finland has shifted towards a parliamentary system by adopting the new unified constitution in 2000). Yet, Finland takes a diametrically opposite approach in linguistic issues. Language Act no. 423/2003 stipulates that Swedish is the second national language in Finland. This means that as far as state communication with citizens is concerned, the officially used language of the newborn citizen will be the one that was requested by the parents upon birth. It is a declaration that can be changed by the individual later on if so desired. As far as local administration is concerned, a municipality is either unilingual or bilingual a status which is determined every ten years based on official statistics. A municipality is designated bilingual if the population includes both Finnish and Swedish speakers and the minority comprises at least eight percent of the population or at least 3,000 persons. A bilingual municipality is designated unilingual if the minority comprises less than 3,000 persons and its proportion has decreased below six percent. ${ }^{223}$ While there are some considerable challenges in the implementation of this model of bilingualism, surveys show an overall satisfaction

223 Section 5 (2) 5 of $423 / 2003$. Available:


of Swedish-speaking citizens with regard to state services in Swedish language, ${ }^{224}$ while most apparently, bilingualism did not tear apart the political and social fabric of Finland but rather contributed to the preservation thereof.

\subsubsection{Reactions to Procedural objections}

I. The fact that an administrative unit is not listed in the constitution of the country does not mean that it automatically becomes unconstitutional. NUTS regions, for example, are not mentioned in the constitution they still function, and are vested with widespread financial authority.

The autonomous region can fit in the present administrative system as an autonomous county, whose internal administrative division could be regulated by the Statute of Autonomy. Unique internal divisions of autonomous administrations which revitalize historic administrative units can be found in Catalonia's Comarca system or in the Basque Country where the historical regions (Bizkaia, Álava, and Gipuzkoa), which only exist there, are pivotal elements in the exercise of the fiscal autonomy of the region. The reestablishment of the historical administrative units of the Seats would be in line with Law 2/1968, as it would take into account sociopolitical, ethnic, cultural and traditional ties of the population.

II. The fact that the DL makes reference to Art. 117 (3) CR might seem somewhat misplaced at first, given that this article appears in the section on "specialized central public administration", whereas local public administrations are being dealt with under the following section (Articles 120-123). The scope of the activities of specialized central public administrative authorities is national, which would certainly not be true to the institutions of an autonomous Szeklerland. Even so, invoking this article is relevant in so far as it would be central public authorities conferring competencies to the autonomous region authorizing it to make decisions for Szeklerland in matters which otherwise would fall under the jurisdiction of the

${ }^{224}$ The quality of state services in Swedish language received an average of 7.6 points (out of a total of 10 points) from the Swedish speaking citizens, based on the availability of services in Swedish. Source: Government of Finland (2009), p. 25. 
central public administration. From the point of view of the state, this would mean that as of the entry into force of the organic law on the status of Szeklerland, the legislative and executive competencies would no longer be carried out by the central administrative authorities but by decision-making bodies of the autonomous region, to the extent that the statute of autonomy allows for it. In other words, in relation to Szeklerland, a set of nationwide competencies of central administration bodies would be taken over fully or partially by the autonomous authorities of Szeklerland. As Stanomir notes, the very essence of autonomous administrative authorities is that they are not subordinated to the government but they share relations with the Parliament in varying forms. Autonomy clearly alludes to the lack of centralgovernmental coercion and the capability to act freely within the boundaries set out by law. ${ }^{225}$ The shear fact that the constitution refers to various forms of autonomy as instruments that can be established through legislation is in itself a valid argument that autonomy per se does not contradict the constitution, given the assumption that provisions of the constitution do not contradict one another. This interpretation is also in line with the basic principles laid down in Article 120 (1) $\mathrm{CR}$, according to which public administration in territorial-administrative units shall be based on the principles of decentralization, local autonomy and deconcentration of public services.

The legislature of the constitutional model country, France, also inserted a similar provision in to the constitution as they saw such provision to help to accommodate increasing regional demands for bigger self-rule within a unitary state structure. Since the constitutional amendment of 28 March 2003, Article 1 of the constitution now stipulates that France shall be organised on a decentralised basis. The same amendment introduced more specific regulations on how to transfer powers from the central government to the territorial communities (Articles 72-1.72-4.). ${ }^{226}$ Lastly, the analogy of devolution in the UK is worth mentioning, given that the predecessors of the devolved parliaments, the Scottish and Welsh Offices, were ordinary Whitehall departments in the beginning, ${ }^{227}$ whose competencies

${ }^{225}$ Stanomir (2010), p.50.

${ }^{226}$ For a more detailed description on local governance in France see: Boyron (2013), pp. 206-235.

${ }^{227}$ Whitehall department is short for British government departments. 
were gradually assumed by the respective regional legislative assemblies when these were re-established in the late nineties.

III. Pursuant to the Legislative Councils conclusions on the necessity to hold a referendum, Szekler Communes started to adopt municipal resolutions to organize local referendums. Eleven municipalities adopted such resolutions ${ }^{228}$ posing the question whether or not the citizens agree that by modifying the current county borders, Szeklerland should become an autonomous territorial administrative unit, which the given municipality should form a part of. In line with Opinion 102, these resolutions based their legality on Law No. 215/2001 on Local Public Administration, and also on Law 3/2000 on the Organization of the Referendum, Art. 13 (1) of which stipulates that "issues of particular interest for an administrative-territorial unit may be subject, under this law, to the approval of the population by local referendum." Moreover, paragraph 3 of the same article states that "legislative proposals on amending the territorial delineation of municipalities, cities and counties, shall be submitted to the Parliament only after consultation with the citizens of these administrative-territorial units by referendum. In this case the referendum is binding." The constitutionality of these resolutions was contested by the Prefects of Kovászna and Hargita Counties before the Administrative Courts on the following grounds: Art 12 (1) b) of Law 3/2000 stipulates that the adoption of a special policy decision on the organization of local public administration, territory, as well as general rules on local autonomy is a question of national interest, and subject, therefore, to nationwide referendums. In this sense, the territorial distribution of a country surpasses local interest and constitutes a national level of interest. The courts also reaffirmed the most common counter-argument that the referendum would result in the establishment of an administrative unit not foreseen by Art 3 (3) of the Constitution and is therefore unconstitutional. Consequently, the court declared all eleven resolutions null and void. The phrasing of Act 3/2000 is vague enough to give birth to dissenting interpretations (especially

${ }^{228}$ These eleven municipalities were: Farkaslaka, Gyergyóalfalu, Gyergyószentmiklós, Illyefalva, Kápolnás, Kézdivásárhely, Mikóújfalu, Nagyborosnyó, Sepsibükszád, Szentegyháza, and Vargyas. Plaints of the Prefects against these resolutions can be found under: http://sznt.sic.hu/husic/index.php?option=com_content\&view=category\&id=20\&Itemid=26\&lang=hu, accessed: 2015.05.08. 
when comparing Articles 12 and 13). Still, it is fair enough to say that the adoption of special policy decisions on local administration that is binding for the whole country and is thus subject to referendums on the national level (Art. 12) should not be confused with referendums on issues of particular interest for an administrativeterritorial unit and with referendums on the delimitation of the borders of the administrative units (Art. 13), in which local citizens have to be invited to the polls even if the final decision might be taken on a higher level by the national Parliament. It should be noted that after these proceedings the Szekler National Council decided to organize an informal referendum, meaning that they established their own mobile ballot boxes and ballots and directly visited the local electorate from December 2006 till February 2008. They reached about 395.000 voters out of which 210.000 cast their votes. 99,31\% was in favour of creating an autonomous Szeklerland. ${ }^{229}$ The case of the local referendums shows that in practice the approval or disapproval of the legality of a referendum on the borders and status of Szeklerland is contingent on discrepant interpretations of different state institutions on the same legal texts.

\subsection{Reactions to Decision Nr. 80/2014}

In his Dissenting Opinion Judge Puskás Bálint Zoltán claimed that the CCR refused to consider both the existing national and international legal framework and the elements of comparative law. By ignoring those grounds, the Court pronounced a wrong solution, based on an artificial argumentation. ${ }^{230}$ Puskás notes that the state is yet to deliver on pledges enshrined in the Declaration of Alba Iulia/Gyulafehérvár. In spite of not being explicitly referred to in the constitution, this declaration has a constitutional legal value. It represents such a direct and genuine manifestation of popular will that it must be respected, recognized and developed at all times, because it lays down the foundations of the Romanian state, as a result of which these values and principles remain immune to the passing of years. ${ }^{231}$ Given that national minorities are members of the national state

\footnotetext{
${ }^{229}$ See Appendix No. 2 in: Szekler National Council (2009), p. 102.

${ }^{230} \mathrm{CCR}$, supra note., p. 74.

${ }^{231} I d$. at, p. 77.
} 
as equal citizens of the country, the acknowledgment of an administrative-territorial organization which recognizes the historical realities does not in any way affect the legal relationship between a state and its citizen. Moreover, the initial proposals did not intend to alter or limit the unitary and indivisible character of the state, on the contrary, they organically blend into the said provisions of the Constitution. Declaring the analysed legal solution unconstitutional calls into question the good faith of the CCR`s interpretation. ${ }^{232}$ Underpinning this argument, Puskás refers to the wording of Art. 3 of Law 2/1968, the constitutional setting of unitary states, like Spain, Italy or Serbia, whose unity was not affected by granting autonomy to their minorities as well as to the relevant literature of Romanian constitutionalists. Lastly, the dissenting opinion notes the contradiction embedded in the CCR`s viewpoint regarding the establishment of decision-making bodies under Art. 6 of the Constitution. If the right of persons belonging to national minorities to their identity is truly recognized and guaranteed but they are not allowed to establish their own bodies to implement this right, that would mean that the majority is entitled to impose on the minority the appropriate way they can maintain, express and develop their identity. ${ }^{233}$ A similar critique is expressed regarding the use of minority symbols. If a national minority cannot use its symbols, not even in areas where it represents the overwhelming majority that is equivalent to denying the right of national minorities to identity. ${ }^{234}$

The thoughts of Puskás on identity do not stand alone. A few years earlier similar views were echoed in the Stanomir-report. ${ }^{235}$ As the report concludes, one of the basic principles that has to govern every constitutional amendment process is the protection of the identity of national minorities. ${ }^{236}$ The report characterises the Romanian Constitution as one of the most rigid ones due to Art. 152 (1) which lists a number of provisions not subject for revision at all. ${ }^{237}$ This approach stems from fears that coined the 1991

\footnotetext{
${ }^{232} I d$. at, p. 78.

${ }^{233}$ Id. at, p. 77.

${ }^{234} I d$. at, p. 78.

235 In 2008, the President of Romania initiated the establishment of a Commission made up of constitutional law experts chaired by Ioan Stanomir Professor at the University of Bucharest in order to investigate the possibilities of revising the constitutional structure of the country. For the full report see: http://www.jakabffy.ro/magyarkisebbseg/pdf/02stanomir.pdf, accessed: 2015.04.19.

${ }^{236}$ Stanomir et al (2010), p. 89.

237 These are: the national, independent, unitary and indivisible character of the Romanian state; the republican form of government; territorial integrity; independence of justice; political pluralism; and the official language.
} 
constitutional process (like separatism and isolation based on ethnic criteria), and which should be surpassed in a new constitutionalization process, as these inhibit the possibilities of legal development by generating artificial conflicts. ${ }^{238}$

Assertions of the $\mathrm{CC}$ show that judges can contribute to interpreting public law provisions in a manner that is hostile to autonomy. It also shows how overarching the tacit agreement on the ethnocentric nation ideal is.

\subsection{The Eye of the Duck - Legal entrenchment ${ }^{239}$}

Now that we have presented the pros and cons and outlined the different views of the majority and the minority on autonomy, we can address the core of the issue at hand. When it comes to legal arguments about the constitutionality of an autonomy arrangement, this core is the legal entrenchment, i.e. the practical way to anchor an autonomous legal regime within the constitutional system of a given state. When elaborating this Chapter, I took into consideration the type of entrenchment that the Draft Law on the Autonomy of Szeklerland envisages, not excluding, however, some examples that might be of relevance, bearing in mind that the Draft Law is not carved in stone but is open for changes as part of a dialogue between the state authorities and representatives of the Szekler community.

Much favourable for national communities who are in pursuit of more selfgovernance and for states willing to address such aspirations, a broad selection of examples is available to draw inspiration from. The autonomous republic of Tatarstan, for example, fits into the constitutional system of the Russian Federation through a special bilateral treaty (signed on 15 February, 1994), as opposed to other sub-state units of the federation which signed the multilateral Russian Federal Treaty. Another unique example would be that of Puerto Rico. Ceded to the United States by Spain as the consequence of the Spanish-American War in 1898, the autonomy of the Commonwealth of Puerto Rico originated in its status as an "unincorporated territory" of the US, which meant that its

\footnotetext{
238 Supra note, pp. 31-32.

239 The "eye of the duck" is a metaphor invented by American director David Lynch, which refers to a scene in his movies that captures the fundamental essence of the whole film, and which helps the viewer to reconstruct the thinking of the director.
} 
residents did not enjoy certain constitutional rights but were also exempted from certain obligations (most importantly tax-related ones).

The entrenchment of devolution in the UK is peculiar in the sense that it takes place within a common law system, which lacks a written constitution. Even so, the UK example is valuable given that before the reestablishment of the Scottish Parliament and the Welsh Assembly in the late nineties, the country used to be as centralized as contemporary Romania. This slowly evolving devolution processes gained new impetus with the BREXIT referendum ${ }^{240}$ after which both the federalisation of the country and the breakaway of Scotland and/or the unification of Ireland and Northern- Ireland are plausible scenarios. Even if Scotland seceded from the UK in the future, the type of devolution it had enjoyed from the adoption of the Scotland Act until the construction of a separate state is worth studying. With respect to Scotland there are no de jure special rights regarding the amendment of the Scotland Act that enumerates the competencies of the autonomous legislature. ${ }^{241}$ The Parliament of Scotland may make laws within its area of competence known as the Acts of the Scottish Parliament notwithstanding, however, the power of the Parliament of the United Kingdom to make laws for Scotland, as set out by Section 28 (7) of the Scotland Act. Deducting its logic from the doctrine of parliamentary sovereignty, ${ }^{242}$ this section provides a clear residual power for Westminster to legislate for Scotland in devolved areas without the consent of Scotland. This provision, however, has never yet been invoked due to the Sewel Convention. ${ }^{243}$ Later on, a Memorandum of Understanding from 2002 between Westminster and the devolved administrations expressed the same position with regard to all of the devolved legislatures, as the Memorandum stipulates that "the United Kingdom Parliament retains authority to legislate on any issue, whether devolved or not. It is ultimately for Parliament to decide what use to make of that power. However, the UK Government will proceed in

\footnotetext{
${ }^{240}$ BREXIT is a portmanteau word that combines the words "British" and "Exit" to refer to the United Kingdom European Union membership referendum held on 23 June, 2016.

${ }^{241}$ While some scientists refer to the Scotland Act as the "Constitution" of Scotland (see e.g.: Himsworth (2013), p. 359.), from a legal point of view this Act can be seen as a functional equivalent to the autonomy statutes discussed in this dissertation.

${ }^{242}$ According to the "Diceyan Orthodoxy", the parliament is vested with the power to make or unmake any law and no person or body has the right to set aside or override an Act of Parliament.

${ }^{243}$ The Sewel convention is named after Lord John Sewel, who was the Minister of State in the Scottish Office responsible for the conduct of the Scotland Bill in 1998. He was the MP who first stated during the Lords Committee stage of the Scotland Bill on 21 July 1998 that the Government expected a convention to be established that Westminster would not normally legislate with regard to devolved matters in Scotland without the consent of the Scottish Parliament.
} 
accordance with the convention that the UK Parliament would not normally legislate with regard to devolved matters except with the agreement of the devolved legislature". ${ }^{244}$ In practice, the convention requires a Legislative Consent Motion (LCM) to be put forward by the UK Government, according to which Holyrood has to agree that the provisions of the given Bill should be considered by the UK Parliament, ${ }^{245}$ insofar as the matters fall within the competence of the Scottish Parliament. Since the first session of the Scottish Parliament in 1999 to date, there has been a total of 155 LCMs. Even though the option of withholding consent exists, Holyrood is yet to test the Sewel Convention in that manner as so far all of the LCMs were passed by the autonomous legislature. ${ }^{246}$ An LCM procedure was also required when the UK government wanted to enact amendments to the Scotland Act. Due to some concerns of the Scottish government, this procedure spanned through 2 legislative cycles between its initiation by the Labour government in 2010 and its adoption by the following Conservative-Liberal Coalition in 2012. In spite, this protracted procedure; there was no effort from the British government to override Scottish opposition by passing the Bill without an LCM. In other words, as long as the Sewel convention remains in place, the Scottish autonomy will have a protection under the political conventions of the UK from unilateral amendment of its competencies.

The Faroe Islands enjoy a remarkably wide scope of competencies including also the jurisdiction to conclude international treaties despite the fact that this autonomy lacks a general constitutional entrenchment and was enacted through an ordinary law instead which can be unilaterally amended by the Danish Parliament through a majority vote whenever they wanted to. ${ }^{247}$ However, not once has it happened since the enactment of

${ }^{244}$ Paragraph 13 of the Memorandum of Understanding, as laid before the Scottish Parliament by the Scottish Ministers, January 2002: http://www.scotland.gov.uk/Publications/1999/10/MofU, accessed: 2015.07.13.

${ }^{245}$ Holyrood is an Anglicisation of the Gaelic word halyruid (holy cross), which functions as a metonym for the Scottish legislature located near Holyrood Palace that has served as the residence of Scottish Monarchs since the 16th century.

246 For Legislative Consent Memorandums and Motions by Session see: http://www.gov.scot/About/Government/Sewel, accessed: 2015.07.13.

247 There are opposing opinions as to the status of Greenland relative to the Faroe Islands. One argument would say that ever since the Greenland Home Rule Act (577/1978) was replaced by the Act on Greenland Self-Government (473/2009), Denmark has agreed to recognize that "the people of Greenland is a people pursuant to international law with the right of self-determination" (Preamble of Act 473/2009). This right includes the right to secession under Chapter 8 of the Act. The unilateral amendment of this statute would violate the principles of self-determination as set out by international law which thus grants a higher protection for the Greenlandic autonomy compared to the Faroese one (even though the Greenland SelfGovernment Act is still an ordinary law as far as the hierarchy of norms of the Danish legal system is concerned). On the other hand, however, this argument can be contested by the fact that in the Reports of 
Law No. 137 of March 23rd 1948 on Home Rule of the Faroe Islands that the Danish Parliament has amended this statute or repealed parts of it without the consent of the Faroese Parliament. This mentality is still present decades later and is reflected expressis verbis in Danish Act no. 578 of 24 June 2005 Relating to the Takeover of Affairs and Fields of Affairs by the Faeroe Islands Public Authorities (shortly, Assumptions Act). The preamble of the Assumptions Act stipulates that "this Act is based on an agreement between the Faeroe Islands Home Rule Government and the Danish Government as equivalent parties." One could thus argue that this favourable mind-set of the Danish political culture represents a type of political entrenchment, in so far as the central state power compels itself to seek agreement as opposed to adopt unilateral measures, "in acknowledgement of the special position held by the Faroe Islands within the Kingdom in national, historical and geographical respects". ${ }^{248}$ The cases of the Faroe-islands and Scotland prove that conventions can constitute an effective political entrenchment even in the absence of a constitutional one. ${ }^{249}$

Similarly to the Faroese model, the 1994 organic law on the special legal status of Gagauzia provides exclusive legislative and executive competencies in various matters from culture and education to economy and environment, but given that the law was enacted after the new constitution of Moldova had already been adopted, the Gagauz autonomy had functioned without a general constitutional footing for almost ten years. It was only through the amendment of the constitution in 2003 that Articles 110 and 111

Denmark on the implementation of the ICCPR, both the Faroe Islands and Greenland are considered as peoples under Article 1 of the Covenant. Additionally, a circular note of the Danish government from 7 November 2005 - to all heads of diplomatic missions accredited to Denmark - makes it clear that though Denmark has granted powers to both Faroe and Greenland to conclude agreements under international law, such agreements can solely pertain to matters for which internal powers have been transferred to the respective autonomous entities. Prior to the exercise of this power, the Danish Foreign Ministry must be consulted in both cases. These sources allude to the fact that there is no substantial difference between the legal statuses of the two autonomous regions and that it is indeed the internal from of self -determination that is the available option for both communities. Finally, Article 21 (3) of the Act on Greenland SelfGovernment stipulates that independence is contingent on the consent of the Danish legislature as part of an agreement between Greenland and Denmark. Unilateral form of external self-determination is therefore precluded from the Act, and secession is only possible in the framework of a negotiated process. But then again, a negotiated secession is possible in the case of Faroe as well (or in the case of any other region elsewhere for that matter) irrespective of the fact that the Faroese statute does not explicitly mention a Faroese right to secession.

${ }^{248}$ Preamble of the Home Rule Act of the Faroe Islands.

${ }^{249}$ For more information on the similarities between the Danish "theory of delegation" and the British doctrine on "sovereignty of Parliament", see: Larsen \& á Rógvi (2012), pp. 348-350. 
were inserted providing a general constitutional entrenchment for the autonomy of Gagauzia. $^{250}$

Another special example was that of the Åland Island prior to 1994. Between the entry into force of the initial autonomy act (Law No. 124/1920 adopted on 6 May 1920), and the amendment of the constitution in 1994, Åland enjoyed a quite unique form of entrenchment as an act of exception. ${ }^{251}$ The legal structure of Finland comprised and still does of the constitution (whose amendment requires a two-thirds majority in two consecutive legislative cycles), ${ }^{252}$ ordinary laws (whose adoption requires the majority votes of the MPs) and decrees adopted by the central or local-municipal governments. The lack of organic laws in this system disabled a semi-general constitutional entrenchment, while a general entrenchment was hindered by the fact that the 1920 Autonomy Act was adopted after Finland had already enacted its constitution as a newly independent state in 17 July 1919. Consequently, the autonomy of Åland functioned for almost seven and a half decades without a general or semi-general constitutional entrenchment. ${ }^{253}$ Unlike Faroe, Greenland or Gagauzia before 2003, however, this sui generis position did not mean that the Finnish governments would have been able to unilaterally amend the statute of autonomy. The ålandic autonomy was firmly entrenched as an act of exception, ${ }^{254}$ which means that Law No. 124/1920 was adopted by the parliament under the same procedure that was otherwise exclusively reserved for the amendment of the constitution but without making the Autonomy Act a part of the formal constitution of Finland or without declaring the Act constitutional. ${ }^{255}$ As far as the doctrine of the acts of exception is concerned, when a political community encounters an exceptional political situation that produces compelling reasons, the parliament may

\footnotetext{
${ }^{250}$ See Weller et al (2010), p. 242.

${ }^{251}$ Suksi (2011), p. 145

${ }^{252}$ An important difference between the current constitution and the one that was in force during the adoption of the Åland Autonomy Act is that after Finland gained independence, the country functioned under a multi-documentary constitutional system consisting of 4 Constitutional Acts: the 1772 Form of Government Act, the 1789 Union and Security Act, the 1906 Parliament Act, and the 1906 Act on Freedom of Speech, Assembly and Association. The new constitution that merged these documents into on unified constitutional text was adopted on 1 March 2000. For more information on the evolution of the Finnish constitution, see Chapter 5 of Dawn (ed.) (2011), pp. 87-115.

${ }^{253}$ For the text of the first constitution see: http://www.servat.unibe.ch/icl/fi01000_html, accessed: 2015.06.30.

${ }^{254}$ The Autonomy Act was completed by a special Act on the Acquisition of Land on the Åland Islands, which had the same sui generis legal entrenchment and amendment procedure as the Autonomy Act.

${ }^{255}$ The lack of such a declaration is relevant because of the multi-documentary nature of the constitutional structure of Finland at that time.
} 
adopt an ordinary act of law using the procedure prescribed for constitutional legislation whose provisions from a material point of view are in breach of the constitution. The "exceptional political situation" in the case of Alland came in the face of a secessionist movement. Under the leadership of Julius Sundblom, the Swedes established their own parliament and brought forth a petition addressed to the Swedish government fostering the merger of Åland and Sweden, invoking the principle of self-determination of the peoples. ${ }^{256}$ The petition campaign was completed on 29 June 1919 and was signed by 9735 people who supported the Union with Sweden, while 461 persons refused to sign the petition (the total population of the islands was approximately 21.000 at that time). The situation also had its international resonances, as there were attempts already in 1919 to refer the case of Åland to the Versailles Peace Conference, which ultimately failed, given that Sweden was not a belligerent party and remained neutral throughout the course of the First World War. Some authors also claim that the granting of autonomy was much more influenced by external rather than internal factors. According to this theory, after the Ålandic issue was referred to the Council of the League of Nations, the Finnish government anticipated that the decision might not be in favour of Finland and they adopted Law 124/1920 only to improve their chances before the Council. ${ }^{257}$ Nonetheless, the times were exceptional for Finland which gave enough incentive to legislate in an extraordinary manner. Normally, one would have needed a two-thirds majority in the Finnish legislature, the Eduskunta, for a constitutional amendment to take place, precluding those instances where the legislature votes for an amendment to be adopted under expedited order. In that case the Eduskunta would first have to vote for an expedited order with $5 / 6$ of its members and have a following vote on the amendment itself requiring this time a 2/3 majority. This was exactly the case with Åland Autonomy Act, where the Eduskunta first approved the expedited order with a 5/6 majority (158 yeas and 21 nays), and then voted for the Act itself with 152 yeas, 27 nays and 1 abstention on 6 May 1920. Such extraordinary legislation happened quite a lot of times during the turmoilish first years of the Finnish state. What was so special with Åland, however, was that the Islands received the additional insurance that the Autonomy Act could only be amended in the same manner as the Constitution and with the consent of the Legislative Assembly of Åland, while other acts of exception could have been repealed by the Finnish legislature

\footnotetext{
256 See more in: Suksi (1993), p. 220.

${ }^{257}$ See: Hannikainen (1997), p. 58.
} 
with a simple majority through an ordinary act. The Constitutional self-limitation that Finland imposed on itself was quite robust here in spite of the lack of a general constitutional entrenchment. The Allandic case provides a vivid example that in the presence of political will a specific minority issue can be resolved, even if the resolution requires the central state to resort to extraordinary constitutional-legal means. ${ }^{258}$

Similar to the case of Åland, the Paris Agreement (also known as the Gruber-de Gasperi Agreement named after Italian Prime minister Alcide de Gasperi and Austrian Foreign Minister Karl Gruber who signed the treaty on 5 September 1946) sought to "safeguard the ethnic character and the cultural and economic development of the German language group" of South Tyrol (Article 1, Paris Agreement). This Agreement was annexed to the Peace Treaty of Paris, published in the Gazette of the Italian Republic on 24 September 1947, becoming a part of Italian legislation. Unlike the Agreement between Sweden and Finland on Åland, the Paris Agreement took the form of a treaty and ensured leverage for Austria as a party to the treaty that could appeal against non-implementation. The obligation of Italy to grant special status to South Tyrol was thus already part of the domestic legal system when the Italian Constituent Assembly adopted the new constitution on 31 January 1948. Consequently, this constitution referred to the special status of South Tyrol. This general constitutional entrenchment has remained in place since then. The satisfying implementation of the Paris Agreement, however, commenced after several decades and a wave of bomb attacks aimed at the secession or South Tyrol from Italy orchestrated by the South Tyrolean Liberation Committee (Befreiungsausschuss Südtirol). ${ }^{259}$

Art. 116 of the Constitution of Italy (CI) enumerate the five special regions of the country that exist beside the 15 ordinary regions (the special regions are: Sicily, Sardinia, the Aosta -valley, Friuli-Venezia-Giulia, and Trentino-Alto Adige/ Südtirol). Since the

\footnotetext{
${ }^{258}$ A detailed summary of the procedure pursuant to which the Statute of Åland was adopted can be found in: Finlands Riksdag (1920), pp. 86-87.

${ }^{259}$ The discord of the South Tyroleans was due to the fact that the first autonomy statute adopted in 1948 gave autonomous competencies to the Italian majority region of Trentino-Alto-Adige instead of the overwhelmingly German-speaking Südtirol Province, and the neighbouring bilingual townships as foreseen by the Paris Agreement. Invoking the non-implementation of the Gruber-de Gasperi Agreement, Austria raised the South Tyrolean question before the UN General Assembly that adopted two resolutions on the issue in 1960 and 1961. Pursuant to these resolutions, Italy then set up a commission of inquiry with the mandate to find solutions to the South Tyrolean question. This organisation called Commission of Nineteen was the one that adopted the "Package" consisting of 137 measures to alter the existing legal regulations on the autonomy of Tyrol, which resulted in the revised autonomy statute that entered into force in 1972.
} 
amendment of the Constitution in 2001, Article 117 has listed the exclusive competencies of the state that includes national questions such as foreign policy, defence, judicial powers, social security, citizenship, currency and so on. Other competences that fall outside this exclusive enumeration were passed to the regions (with the difference that ordinary regions have to follow state guidelines in concurrent competencies), the resolutions of which can only be contested by the government through the Constitutional Court (whereas before the 2001 amendment the government was able to refer regional laws back to the regional government). ${ }^{260}$ On the other hand, special regions have exclusive or shared powers in the fields of economics (including the retention of locally generated tax revenues), education, culture, environmental issues...etc, enumerated by their respective special statutes. The case of South Tyrol is peculiar even within the five special regions not just because of the international entrenchment but also because South Tyrol, as a province within Trentino-Alto Adige region, exercises competencies that in the other four cases are allocated to the regional level. Thus, there is a complex 8 level system of power sharing: Exclusive legislative powers of the State ${ }^{261}$; Concurring legislative powers shared by the State and its Regions ${ }^{262}$; Exclusive legislative competencies of Trentino-Alto Adige region ${ }^{263}$; Exclusive competencies of the autonomous provinces of Trento and Bolzano ${ }^{264}$ (a.k.a. primary jurisdiction from the autonomous entities point of view); ${ }^{265}$ Concurring legislative powers shared by the State and Trentino-Alto Adige Region; ${ }^{266}$ Concurring legislative powers shared by the State and the Province (secondary jurisdiction), ${ }^{267}$ Powers to enact the provisions of national

\footnotetext{
${ }^{260}$ See: Peterlini (2013), p. 130

${ }^{261}$ Article 117, Paragraph 2, points a) - s) CI

${ }^{262}$ Id. Article 117, Paragraph 3.

${ }^{263}$ Article 4. of the Special Statute of the Region Trentino - Sudtirol, Law No. 118 from 11. March 1972 (hereinafter, ASt).

${ }^{264}$ Article 8. ASt and Article 117. Paragraph 4 CI regarding regional involvement in EU decision-making processes.

265 Scientific literature often approaches the autonomous competencies from the point of view of the autonomous entity, and thus differentiates between primary (or exclusive), secondary (or shared), and tertiary (or complementary) competencies. See for example: Ferrari, Paolo (ed.) (2009).

266 Article 5. ASt, which adds some specific competencies (like organization of public welfare and charitable institutions, local savings banks and credit institutions) that are not present in the general framework as set out by Article $117 \mathrm{CI}$.
}

${ }^{267}$ Article 9. ASt. 
laws (tertiary jurisdiction); ${ }^{268}$ Competencies delegated from the State to either the region or the province. ${ }^{269}$

Since Constitutional Law No. 1/1999 entered into force, the autonomy statutes of both the special and the ordinary regions must be adopted by the national parliament with a constitutional law. ${ }^{270}$ Thus, the autonomy statute of South-Tyrol lies between ordinary laws and the Constitution in the hierarchy of norms meaning that simple majority legislation of the Italian Parliament cannot repeal nor amend the statute. Accordingly, Regional Statutes are adopted and amended by the Regional Council with a law approved by an absolute majority of its members, with two subsequent deliberations at an interval of not less than two months. ${ }^{271}$ The constitutionality of these statutes can be contested before the Constitutional Court by the central government within thirty days of their publication. The statute is submitted to popular referendum if one-fiftieth of the electors of the Region or one-fifth of the members of the Regional Council so request within three months from its publication. The statute that is submitted to referendum is not promulgated if it is not approved by the majority of valid votes. ${ }^{272}$

These provisions provide a firm domestic legal entrenchment of the autonomous statutes, but they also make the statutes quite hard to amend. Consequently, in the case of regions with special statutes, there is a peculiar institutional machinery enabling a more flexible adjustment of the autonomous legal system to eventual new challenges. "All special regions can negotiate with the state the concrete developments of their autonomy, bilaterally and on an equal footing. For each of the five special regions, a joint body of state and regional representatives (in equal number) has been established, with the crucial task of drafting the enactment decrees implementing the regional autonomy statues. These drafts are submitted to the national government, which approves them in the form of governmental decrees. The decrees are by-laws of the autonomy statute and cannot therefore be abrogated or amended by the laws of the national parliament. ${ }^{273}$ This is due to the so-called 'principle of specialty', according to which special regions have a

\footnotetext{
${ }^{268}$ Id. Article 10.

${ }^{269}$ Id. Article 16, Paragraphs 3. and 4., and article 17.

${ }^{270}$ Article 116, Paragraph. 1 CI.

${ }^{271}$ Id. Article 123.

${ }^{272}$ A similar procedure applies to constitutional laws on the national level under Article 138 CI.

${ }^{273}$ This means that enactment decrees in practice lie between constitutional laws and ordinary legislation in the hierarchy of norms.
} 
privileged status with particular regard to negotiations with the state, ${ }^{274}$ which are carried out in a way that is similar to international relations: either there is consensus among the parties involved or the agreement cannot be reached. In other words, the relations between the state and the special regions are not based on hierarchy but, in principle, on parity. Put differently, the existence of two categories of regions cannot be abolished even by means of a constitutional reform." 275 In South-Tyrol these enactment decrees (Durchführungsbestimmungen) are adopted by the so-called Commission of Six (Sechser-Kommission) consisting of three Italian members (appointed by the Italian Parliament) and three German speaking members (appointed by the South-Tyrolean Landtag).

The case of Italy shows that the constitution of a unitary state can flexibly accommodate a "federalist-like" division of powers (where the state is "only" vested with enumerated powers, and all other legislative and administrative competencies are transferred to the regions), as well as asymmetrical regionalism (whit different levels of competencies even among the special regions) open to further devolution of powers from state to regional or provincial levels. While the Romanian constitution safeguards the unitary and indivisible, national character of the state to the extent that these features may not be the object of a constitutional amendment, ${ }^{276}$ the Italian Constitution safeguards with the same vigour the special status of its autonomous entities, as their competencies cannot be unilaterally abrogated or amended by the national parliament, not even by means of a constitutional reform. Furthermore, the involvement of the kin-state (Austria) and the $\mathrm{UN}$ as mediators in the conflict from the late sixties onwards makes the case of South Tyrol one of the most salient models to analyse from the Szekler point of view.

The Constitution of Spain (CS) is unique in the sense that Section 2 recognizes and guarantees the right to self-government of the nationalities and regions of which it is composed. Under the auspices of this "right to autonomy", the administrative structure is decided by the Self-governing Communities (Comunidades Autónomas), ${ }^{277}$ who are free

\footnotetext{
274 This principle is constantly stated in the case law of the Constitutional Court. See, among others, Judgments No. 20/1956; 22/1961; 151/1972; 180/1980; 237/1983; 212/1984; and 160/1985.

275 Woelk et. al (2008), pp. 39-40.

${ }^{276}$ Article 152 (1) CR.

277 These communities are defined by Art. $143 \mathrm{CS}$ as provinces with common historic, cultural and economic characteristics, insular territories and provinces with a historic regional status. Currently there are 17 Autonomous Communities: Andalusia, Aragon, Asturias, Balearic Islands, Basque Country, Canary Islands, Cantabria, Castile-La Mancha, Castile and León, Catalonia, Extremadura, Galicia, La Rioja,
} 
to decide whether or not they would like to form a common province or accede to an existing one. ${ }^{278}$ This so-called dispositive principle (principio dispositivo) ${ }^{279}$ allows for a structure that is permanently open at the "disposal" of the autonomous communities. ${ }^{280}$ The scope of the competencies they can assume is equally flexible. Section 149.1 enumerates the exclusive competencies of the central state, such as international relations; ${ }^{281}$ immigration; defence; administration of justice; ${ }^{282}$ commercial- criminalcivic- or labour legislation, regulations on customs, tariff and foreign trade; or basic legislation on the financial system, health- and on social security...etc. ${ }^{283}$ But matters not expressly assigned to the State by the Constitution may fall under the jurisdiction of the Self-governing Communities by virtue of their Statutes of Autonomy, while jurisdiction on matters not claimed by Statutes of Autonomy shall fall with the State. ${ }^{284}$ The competencies that the Communities can assume are enumerated under section $148 \mathrm{CS}$ and include fields such as: organization of own institutions; urban planning, and housing; public transportation; woodlands and forestry; agriculture and fisheries in accordance with general economic planning; administration of local cultural institutions (schools, museums, libraries). The precise enumeration of competencies is particularly important, given that state law and regional legislation enjoy the same legal value, meaning that in case provisions of these two forms of legislation clash, the law will prevail that was adopted by the legislature, which possesses jurisdiction over the given subject. Due to this legal equality, it is the Constitutional Court alone that can decide in

Madrid, Murcia, Navarre, Valencia, and two autonomous cities on the northern coast of Africa: Ceuta and Melilla.

${ }^{278}$ Section 143 CS.

${ }^{279}$ For a broader explanation of this principle, see among others Constitutional Court Decision 247/2007 from December 12.

${ }^{280}$ The constitution also differentiates between a fast-track (Art. $151 \mathrm{CS}$ ) and a slow assumption of powers (Art. 143 CS). In most cases the latter one was chosen.

${ }^{281}$ Notwithstanding the exclusive competencies over foreign affairs, there is an institution called the Conference on Issues Related to the European Union (Conferencia para Asuntos Relacionados con la Unión Europea - CARUE), aimed to channel the views and interests of the Autonomous Communities regarding EU decision-making before Madrid adopts a position on various EU policy issues. A similar parity-based organ was established through organic law 8/1980 called the Council of Fiscal and Financial Policy (Consejo de Política Fiscal y Financiera), in order to adapt the coordination between the financial activities of the Autonomous Communities of the State Treasury.

${ }^{282}$ While the legislative and executive branches are decentralized, the judicial power remains an exclusive power of the State.

${ }^{283}$ The CS also allows the state to lay down the basics of a field to be regulated while leaving it to the Communities to enact the detailed regulations or to ensure the regional administrative enforcement of state level legislation.

${ }^{284}$ Section 149.3 CS. 
such cases which law prevails over the other. ${ }^{285}$ Ordinary judges cannot perform such scrutiny. Thus, this system allows for the gradual development of asymmetric regionalism providing the Self-governing Communities wish to expand the scope of their jurisdiction. However, such expansion of competencies has its own limits some of which came particularly well to the fore when the Catalan Parliament adopted a new Statute of Autonomy on 30 September 2005, which aimed to widen the powers of the Generalitat de Catalunya. ${ }^{286}$

In general, the text of the Statutes of autonomy is adopted by the respective regional legislatures but is subject to the approval of the Spanish Parliament (Cortes Generales), ${ }^{287}$ which in practice means a political veto, and not just a constitutional one, as we saw in Italy (as Arzoz characterises this system: "the autonomy statutes were denied a constitutional role in the process of developing the decentralisation model"). ${ }^{288}$ The text then has to be approved on a referendum after which the Constitutional Court can still exercises scrutiny over the statutes' compliance with the Constitution and can overrule provisions or define the interpretation thereof. However, once enacted, the autonomy statute cannot be unilaterally amended by the central government. ${ }^{289}$

It was against this backdrop that the mentioned amendment of the 1979 statute of autonomy of Catalonia took place. After the overwhelming majority of the Catalan Parliament voted in favour of the text (125 in favour, 15 against out of a total 135 representatives), the statute was submitted to the Spanish legislature where about half of the provisions were already repealed as part of a deal with the then governing socialist party (PSOE) in January 2006. The Congress and the Senate both approved the new Statute on 10 May 2006 when the amended text passed through its final reading with the support of all parties except for the Spanish main opposition party, the conservative

\footnotetext{
${ }^{285}$ The Constitutional Court's scrutiny, however, is a point where there is a difference between national and regional legislation, as the CCS can suspend the application of regional laws but not national ones.

${ }^{286}$ The term Generalitat refers to the three main decision-making institutions of, including the Parliament of Catalonia, the President of the Generalitat de Catalunya and the Government of Catalonia.

${ }^{287}$ Section 147.3 CS.

${ }^{288}$ Arzoz (2012), p. 187.

${ }^{289}$ In theory the only way for the central government to unilaterally encroach upon autonomous competencies is adopt „laws of harmonization”. As Article 150.3 CS stipulates, the State may enact laws laying down the necessary principles for harmonizing the rulemaking provisions of the Self-governing Communities, if general interest so requires. However, the Constitutional Court has been restrictive in the interpretation of this rule, and has annulled the only harmonizing law that has so far been adopted (See ruling STC 76/1983).
} 
People's Party (PP), and the Catalan separatist party Esquerra Republicana de Catalunya. On 18 June 2006, the new statute was approved in a referendum gaining the support of $73.9 \%$ of the participating electorate. In early 2006, PP members of the Cortes filed an appeal against the new Statute with the Constitutional Court of Spain (CCS) arguing that 126 articles were unconstitutional and that the French model of popular sovereignty applies also to Spain: "It can be said, with reason, that the centralism characteristic of French constitutionalism is not comparable to the Spanish constitution of 1978. But what is without doubt identical to it [in our constitution] is the concept of the people. The question is of enormous constitutional relevance because the concept of the people is used for nothing less than to attribute to it national sovereignty. National sovereignty is not fragmentable and still less, consequently, is the Spanish people. This is not a federative concept, formed by grouping the peoples of the different Spanish communities. The individual components of this sovereign people ... are the citizens. All of them belong to a single category, not to be differentiated territorially". ${ }^{290}$ The appeal dragged on for four years. In the meantime, the terms of four judges expired in late 2007 (and one place was vacant since 2008 due to the death of one judge), but for political reasons they were not replaced. Finally, in late June 2010, after 4 years of deliberations, a divided court rendered 14 articles of the statute unconstitutional and 27 others subject to further legal opinion (while also criticizing much of the PP appeal as inaccurate and badly argued). ${ }^{291}$ For the purposes of this study, this latter group of provisions are more interesting given that it shows the importance of being "legally open-minded" to decentralization and the will of local communities.

Decision no. 31/2010 of the CCS vividly demonstrates the importance of how one interprets statutory provisions. Instead of rendering some of the provisions that were deemed by PP critics as unconstitutional, the Court provided an interpretation which allows for these provisions to remain in place given that they are interpreted in a specific manner (much to the dismay of the Catalan Parliament, these interpretations were

\footnotetext{
${ }^{290}$ Introduction of PP`s appeal to the Constitutional Court as quoted by: Friend (2012), p. 105.

${ }^{291}$ Rejection applied to articles concerning judicial powers of the Council of Justice of Catalonia, some financial powers of the Taxation Agency of Catalonia as well as some linguistic competencies.
} 
unacceptable for them in many ways). ${ }^{292}$ For this reason, it is worth mentioning some of the findings of this ruling.

Some of the contested provisions of the New Statute of Autonomy of Catalonia (NSAC) alluded to symbolic issues. The Preamble stipulated that the Parliament of Catalonia defined Catalonia "as a nation by an ample majority" and that "The Spanish Constitution, in its second Article, recognizes the national reality of Catalonia as a nationality". Accordingly, Article 8 of the NSAC described the flag, the holiday and the anthem of Catalonia as "the national symbols of Catalonia". These articles have been challenged for classifying as "national" the symbols of Catalonia, which were believed to contradict the concepts of unity and indivisibility as set out by Section 2 CS. The CCS mentions that ,it is indeed possible to speak of nation as a cultural, historic, linguistic, sociological and even religious reality. But the nation of importance here is solely and exclusively the nation in its legal and constitutional sense". ${ }^{293}$ This means that, as far as constitutional law is concerned, the term ,nation” can only be interpreted as a civic bond between all citizens of Spain irrespective of their cultural identity. Consequently, the interpretation of the references to "Catalonia as a nation" and to "the national reality of Catalonia" in the preamble of the NSAC have no legal effect. In other words, while the communities of Spain have the right to self -government, the exercise of this right can only happen within the indissoluble Spanish nation, where the concept of the "nation" connotes the civic understanding of a political community composed of all citizens of the Spanish state and can only be used by a sub-state entity for self-identification within these constitutional boundaries. Finally, as far as "national symbols of Catalonia" are concerned, this wording can allude to a manifestation of the right recognized under Section 2 CS with "no intention to challenge the competency or counteract the symbols of the Spanish nation".

With regard to linguistic issues, the Generalitat attempted to place Catalan on equal footing with Castilian by stating under Article 6 (2) NSAC that ,all persons have the right to use the two official languages and citizens of Catalonia have the right and the duty to know them". These provisions were inspired by Section 3.1 CS, which lays down

${ }^{292}$ See Legal Report of experts commissioned by the President of the Generalitat as a response to CC Decision 31/2010: http://premsa.gencat.cat/pres_fsvp/docs/2010/07/21/12/11/76d06239-427f-48da-a5335cf2492b43ea.pdf, accessed: 2016.07.13.

${ }^{293}$ Paragraph 12 of Decision 31/2010. 
the duty of all Spaniards to know Castilian. In the CCS's opinion, these provisions would be unconstitutional and null if their intention was to impose a duty to know Catalan, equivalent in meaning to the constitutional duty to know Spanish. However, the CCS noted that there is a different possible interpretation, according to which the "the duty to know Catalan” refers to a mandate of the public powers of Catalonia „to adopt the measures necessary to facilitate compliance with this duty". ${ }^{294}$ In this context, the duty to know Catalan would create liability for Catalan public institutions to build up capacity to be able to communicate and teach in Catalan, whereas the duty to know Castilian applies to all citizens of the state. Linguistic issues came also to the fore with regard to education. Article 35.1 NSAC stipulates that "each individual has the right to receive an education in Catalan", and that "Catalan shall be used as the teaching and learning language for university and non-university education". The CCS notes that even though this article does not refer to Spanish as a teaching language, this cannot be understood deliberately to order an exclusion. While "it is perfectly legitimate for Catalan to be the centre of gravity of this model of bilingualism ... both languages must be not just taught, but also a means of communication in the educational process as a whole, both co-official languages constitutionally must be recognized by the public powers as teaching and learning languages and therefore each individual has the right to be taught in either of them". 295

The most instructive part of CCS decision 31/2010 in comparison with the Szekler case was probably the one pertaining to the internal administrative borders of Catalonia. Articles 83, 90 and 91 NSAC mention Vegueria as the new administrative unit of local government in Catalonia (responsible for the territorial organisation of its services), ${ }^{296}$ whose executive council should supersede that of the province. ${ }^{297}$ The challenge to the Vegueria system was dismissed by the CCS "because the territorial division of the State into provinces, generally speaking, is not affected by it, nor, more particularly, is the division of Catalonia into the four provinces currently existing... since the constitutional guarantee of the province as a local entity does not exclude the existence of other supra-

\footnotetext{
${ }^{294} I d$. at, paragraph 14. b.

${ }^{295} I d$. at, paragraph 24.

296 The vegueria was the feudal administrative territorial division of the Principality of Catalonia between the 12 th and 18 th century.

${ }^{297}$ Catalonia is currently divided into 948 municipalities, which are organized into 42 comarcas, included in 4 provinces.
} 
municipal government entities". ${ }^{298}$ The conclusion of the CCS was that the autonomous administration in practice is free to develop whatever local administrative structure it deems appropriate for the organizations of services that fall in their competencies (even concurring, multi-level structures) as long as they maintain the administrative capacities for the fulfilment of state activities. In this sense, the executive branch of Veguerias could even replace that of the provinces, but only if "the State legislation determines their composition, the form in which its members are elected, as well as the basic state standards regulating their competencies in the local arena"; ${ }^{299}$ and only if their geographic borders coincide, given that Section 141.1 CS states that ,any alteration of provincial boundaries must be approved by the Cortes Generales in an organic act.".

As described earlier in Chapter 2.2.2, one of the procedural objections against the reestablishment of the traditional Szekler Seats, as internal administrative units of an autonomous Szeklerland, was that no such unit is mentioned in the constitution and that this would result in a 3 level municipal structure, as opposed to the usual 2 level system of any other county of Romania. In this perspective, it is worth mentioning that the CCS did not find anything unconstitutional in Chapter VII NSAC, which concerns Aran's own institutions. ${ }^{300}$ Aran is an autonomous entity within an autonomous entity. Addressing Aran's cultural specificities, they were granted an autonomous government called the Conselh Generau, which is vested with the power to decide the own internal administrative division of Aran. Consequently, the Aranese executive established a territorial division that exists nowhere else in the whole country, the so-called terçons. The terçó was the traditional territorial division of the Aran Valley from 1313 to 1834. The Conselh Generau decided to re-establish them in 1990, even though the traditional borders of the terçons cross-cut that of the nine municipalities of Aran. Even though Section 141.3 CS stipulates that groups of municipalities other than provinces may be formed, the lack of a similar provision in the Romanian constitution does not constitute a de jure ban on other forms of administrative units.

The example of Spain shows that even a unitary state is capable of accommodating a multi-tier administrative structure, which gives room for the expression of specific

\footnotetext{
298 Supra note, paragraph 40.

${ }^{299} I d$. at, paragraph 41.

${ }^{300}$ Aran is the northernmost comarca of Catalonia where the population speaks Aranese, a form of the Gascon dialect of Occitan, spoken in Val d'Aran.
} 
traditions in the shape of historical local administrative units. Furthermore, the example of Decisions 31/2010 of the CCS shows the relevance of how one perceives a provision and illustrates that interpretative framework of legal provisions can be constructed in a way that fosters the accommodation of autonomy aspirations and promotes "reconciliation" between the central state and its constituent regions aiming to achieve greater self-rule within existing constitutional boundaries. 


\section{Chapter 4}

\section{Conclusions}

History shows that there has always been a certain readiness from the side of Romania to adopt western constitutional patterns and legal solutions, the implementation of which mostly failed due to deficiencies in political culture. Even so, the adoption of such "western" standards were never taken seriously when they pertained to best practices of minority protection, decentralization or power-sharing. Romanian political- and diplomatic elites preferred investing their creative energies in generating the appearance that the country abides by her international commitments regarding minority protection to actually abiding by them. This is the reason why public institutions fail on purpose to fully implement relevant international documents signed and ratified by Romania, and the reason why state policies towards the Hungarian/Szekler community are characterized by general mistrust, forced linguistic inequality, persecution of symbols and criminalization of autonomy aspirations. The long-term aim has continued to be the establishment of an ethnically homogenous nation state. An endeavor which is very much detectable in practices of local and national governments, debates carried out in-, and laws adopted by the parliament, court judgments, fines and protocols of law enforcement agencies or activities of the secret services and other actors of the Romanian deep state. All these different public institutions exhibited in their own peculiar way some typical traits of nation-state thinking: the majority is dominant and superior to the extent that it can impose on the minority separate forms of behavior to follow and dissenting rules to abide by; exercising certain rights is contingent on the approval of authorities in the case of the ethnic Hungarian minority but not for the ethnic majority (as we saw in the case of the DSF); ultimately it is the ethnic majority that is entitled to tell the minority how to live, what language to speak, which identity to pledge allegiance to, and what legal status to enjoy.

Despite the preferences of the ethnic majority on what this legal status should entail, the arguments of the preceding Chapters prove that territorial autonomy as an institutional solution does not contradict the constitutional order of Romania. There are no provisions in the Romanian legal system whatsoever, which would constitute a legal obstacle to the creation of an autonomous administrative unit. Chapters 1 and 152 of the 
Constitution of Romania, so frequently referred to in the autonomy discourse, are thus of no legal relevance and cannot be understood as an effective constitutional legal barrier. On the contrary, the notion of autonomy is not alien to the Romanian constitutional system at all, as it recognizes personal, functional, as well as a certain degree of territorialadministrative autonomy. The only existing obstacle to a Szekler autonomy arrangement is a political one. The assumption that autonomy contradicts the constitutional order and violates the unitary, indivisible and national character of the state arises from the misinterpretation of the connection between state and autonomy. These misconceptions can be traced back to the historic resentment that is present in Romanian political culture towards Hungarians and the parallel nation-building processes of Hungarians and Romanians that have been unfolding for more than a century now. Fears of autonomy are also fuelled by weak rule of law traditions and insufficient experiences in democratic governance. The tacit agreement on full rejection of autonomy produces conceptual restraints, which blind nation-state enthusiasts to alternative and possibly more effective ways the state machinery could function. This is how referring to Article 1 of the constitution becomes a mental shortcut to avoid a meaningful discussion on territorial autonomy. This is also where the inspiration came from to invite readers of this dissertation to engage in a mind-game in order to deconstruct the "constitutional myth". What we intended to illustrate is that a "simple" change in the mind-set can remove an unnecessary and unjustified, albeit seemingly robust obstacle to a legitimate minority claim.

With this in mind, the most relevant conclusion that can be deducted from the numerous different forms of legal entrenchment presented above is that in the presence of political will, minority claims can be accommodated even if the resolution requires the central state to resort to special means. In the case of the Åland Islands, the autonomy statute was provided with a firm general constitutional entrenchment and protection against unilateral amendment by the central governments. As an act of exception, this statute was unique in its kind and stood alone in the Finnish legal system for over seven decades. South Tyrol was equally special within the Italian constitutional system, on the one hand, because among the five regions with special statutes, it is the only one to have an international legal entrenchment through the Gruber-de Gasperi agreement, and on the other hand, because in their case the autonomous competencies were granted on a provincial level, while in the other four cases autonomous competencies were granted on 
the regional level. Both Åland and South Tyrol show the importance of active participation of the international community in facilitating a dialogue between a state and its constituent parts striving for greater self-rule. These examples also show that kin-states can have a pivotal role in assisting the aspirations of their compatriots abroad. The devolution of Scotland required the common law system of the UK to change and develop including its pivotal doctrine on parliamentary sovereignty, which is now altered by the Sewel Convention. In other words, with the devolution process the UK Parliament has chosen to exercise its legislative sovereignty in devolved matters through an elected body other than the UK Parliament and reinforced this decision in its political conventions. ${ }^{301}$ The Faroese case shows the importance of political culture in the establishment and functioning of an autonomous arrangement. The relations between Faroe and Denmark are developed under the auspices of equality, consensus building and the respect of Faroese peculiarities, even though in the absence of a general constitutional entrenchment there are no constitutional provisions that would compel successive Danish governments to follow suit with this approach. The example of Gagauzia and the Hungarian Autonomous Province in Romania shows that territorial autonomy can be achieved within central-eastern Europe as well, even though most of the territorial autonomies of the continent exist in Western Europe. Parallel with the numerous flexible legal solutions that were mentioned, the case of the New Catalan Statute of Autonomy showed the importance of a positive attitude from institutions of the central state towards decentralization and the aspirations of a nationality. Judgment 31/2010 of the CCS showed how easy it is to remove a perceived threat (greater autonomy to sub-state entities) by simply presenting an alternative interpretation of a given legal provision. This simple observation is particularly relevant in the case of Romania, where the political culture and the constitutional traditions are overtly ethnocentric. Even so, the text of the Constitution of Romania is not, "all in all, ethnocentric in itself: it allows an opposite, pluralistic interpretation. What must be changed, therefore, is not the constitutional text but the ethnocentric mentality". ${ }^{302}$

One can draw inspiration from the examples and solutions mentioned in this study and apply them to the Szekler case. The Draft Law on the Autonomy of Szeklerland could

${ }^{301}$ Some scholars even argue that autonomy in Scotland and Northern Ireland defies a feature of the Parliamentary Sovereignty doctrine, namely that all statutes are of the same constitutional value. See: Tierney (2014), pp. 159-180.

${ }^{302}$ Selejan-Gutan (2016), p. 43. 
blend into the Romanian legal system as an organic law based on Article 117 (3) of the Constitution. Besides this semi-general constitutional entrenchment, a regional entrenchment would also be present as the Draft Law stipulates that any amendment to the statute should be approved in a local referendum before it can enter into force. While such an arrangement could be flexible enough to follow the changes that inevitably occur in group relations over time, it might also make it doubtful whether such an arrangement would be sufficient enough to protect the local Szekler community in the long run and to ensure the effective participation of the citizens of the autonomous polity in public decision making. Due to the weakly embedded nature of democratic political culture, a political entrenchment that functions effectively in Denmark or the UK cannot be achieved within a reasonable time-frame in Romania. For this reason, an international entrenchment of some kind would be desirable to counterbalance the possible shortcomings of the lack of a general constitutional entrenchment. Such a treaty-based entrenchment would be possible under the auspices of an international organization or can take a bilateral form as concluded between Hungary and Romania.

As a closing remark, one could refer to the thoughts of Count Esterházy János ${ }^{303}$ regarding good minority policy that is also applicable to regional autonomy: "Righteous national minority policy is a considerably bigger coefficient than a number of written laws, it is more secure than any Maginot line, for nothing makes a state stronger than the fact that not only the majority citizens but also the minority citizens feel completely at home". 304

\footnotetext{
${ }^{303}$ Count János Esterházy was an ethnic Hungarian politician in Czechoslovakia during the inter-war era as well as in the First Slovak Republic (a puppet state of Nazi Germany). He was the only parliamentarian of the First Slovak Republic who voted against the law on the deportation of Jews in 1942. Based on fabricated allegations, he was sentenced to ten years of forced labour in Siberia. Additionally, the Slovak National Court sentenced him to death in his absence for contribution to the dissolution of the Czechoslovak state. He was not executed due to a presidential pardon but was transferred around instead from prison to prison over the next ten years. He died in prison in 1957.
}

${ }^{304}$ Quoted by Kardos (2015), p. 40. 


\section{Chapter 5}

\section{Policy implications}

The preceding chapters of this dissertation already imply some conclusions de lege ferenda. ${ }^{305}$ Consequently, I found it important to directly address the possible policy implications that can be deducted from this study. The main task of this chapter would be to identify the corresponding action various actors (State, Minority Community, Kinstate, International community) can undertake in order to assist the establishment of the territorial autonomy of Szeklerland in Romania.

There have been many attempts within academia to gauge past events in an attempt to assess possible "recipes of success" for the future. Shaykhutdinov, for example, conducted a correlation and regression analysis on the self-determination movements of 168 ethnic groups in 87 states between 1945 and $2000^{306}$ in order to assess the impact of violence on the success of those movements. ${ }^{307}$ The statistical analysis showed that the employing peaceful tactics groups employ when seeking greater self-rule is the sole strongest predictor of the formation of an autonomy arrangement. Non-violent movements were about three times more effective at achieving territorial autonomy than ethnic groups that employed violence. ${ }^{308}$ Even though there were some cases where violent tactics played a significant role in an arrangement that introduced autonomy for that community, in most cases these tactics were found counterproductive as they generate mistrust and antipathy towards members of the movement and alienate representatives of the given state as well as actors of the international community. Furthermore, the study identifies some additional factors that are relevant to the Szekler case. A positive correlation with successful autonomy movements was found in cases

\footnotetext{
${ }^{305}$ Latin expression, meaning "with a view to the future law" as opposed to de legelata, the "current law". 306 The analysis only included minority groups that constituted at least $1 \%$ of their country's population or had 100,000 members or more, and had expressed a desire for territorial autonomy or independence at least once between 1945 and 2000. Additionally, groups included in the study resided in countries with a population of at least 500,000 .

${ }^{307}$ Shaykhutdinov (2010), pp 179-191.

${ }^{308}$ This viewpoint is shared also by Daftary in her comparative study between Corsica and the ÅlandIslands where she notes that the low level of militarization of the Åland conflict along with the Finnish democratic political culture were major factors contributing to the success of the Ålandic autonomy movement relative to Corsica. See: Daftary, (2004).
} 
where: the autonomy demand came from larger and geographically concentrated communities (the latter being the more important factor), there were international mediators involved in the autonomy process (state actors were found to have more influence in this regard than international organizations), the political system of the host country could be characterized as democratic.

Cunningham examined the internal fragmentation of the primary actors of any autonomy process: the central governments of states and organizations representing a given minority community. ${ }^{309}$ She argues that the internal structure of both movements for self-determination and national governments structures the negation process in these disputes and the incentives that both sides have for settlement. The author's findings sophisticated the general topos that autonomy movements led by a sole and unified organization are more likely to succeed in winning autonomy than their organizationally fragmented counterparts. Unified movements have the competitive advantage that central governments are less able to deploy "divide and conquer" tactics against them. Thus, the negotiated agreement is more likely to echo the opinion of the whole group, which also makes this option more "costly" to central governments, insofar as it presupposes the fulfilment of all (or at least the majority) of the demands of that group. This scenario decreases the government`s manoeuvring space and pushes the dynamics of the autonomy process in the direction of a zero-sum game. The situation is not the same with internally fragmented movements where the government could use these internal divisions to their advantage by pursuing "divide et impera" strategy and offering autonomy deals that a subset of factions would agree to in an attempt to divide the moderates from the hardliners. This scenario would entail governments satisfying moderate factions with lesser concessions resulting in autonomy arrangements with a more limited scope of powers that are only accepted by a fraction of the group. This in turn could generate discontent among the minority group and make the arrangement more fragile and unstable. ${ }^{310}$ From the government's point of view, this option is more favourable and easier to communicate as it does not jeopardize its own internal structure, which usually is not homogenous but is composed of parties with discrepant preferences. Cunningham states that relatively higher

\footnotetext{
${ }^{309}$ Cunningham (2007), pp. 6-12.

${ }^{310}$ Salat and Constantine further point out that autonomy arrangements that are not accepted by the wider majority of the affected communities can produce severe legitimacy deficit. It was the case with Macedonia and the Ohrid Framework Agreement or the Jewish Autonomous Oblast in Russia. See: Salat et al. (2014), pp. 465-466.
} 
levels of internal fragmentation of minority and majority actors constitute a hurdle for policy change, given that it increases the number of veto players on both sides, makes it more difficult for parties to assess each other's relative bargaining strength and decreases the chances of elaborating an autonomy arrangement that would satisfy the majority of both sides. In summary, Cunningham notes that the chances of reaching an autonomy arrangement are the highest in cases where you have a government with a moderate number of internal veto players ${ }^{311}$ complemented by a minority group, which is either unified or fragmented in a way that allows governments to buy off moderates with lesser autonomy concessions. ${ }^{312}$ In this latter case, the minority group can increase its chances for a deal with establishing a coordinating or deliberative body for the various stakeholders, which decreases the potential of hard-liners to block the acceptance of an autonomy proposal of the government.

Ghai and Woodman indicated on a 5-point scale how strong the correlation was between specific factors and their contribution to the establishment of an autonomy arrangement in 13 different regions. ${ }^{313}$ They found that the most salient factor that facilitated the granting of an autonomous status was general regime change in the host country. Ghai notes that times when the architecture of the state is under review present an opportunity to minorities to assert a variety of claims to the future order including claims on autonomous status (this assertion was true to eleven of the thirteen autonomies covered by the book, which shows the presence of a strong correlation). ${ }^{314}$ The second strongest correlation was found in cases where the international community actively contributed to the establishment of that autonomy. Chances for autonomy were further increased in cases where the territory inhabited by the given national community was relatively small in size and economic significance. Lastly, the presence of a democratic political system and traditions of rule law were found to have helped facilitate autonomy (given that most of the autonomies can be found in liberal democracies). Other authors, however, contested the relevance of democratic political structures in autonomy arrangements and would allude to examples where the host country could not be

\footnotetext{
${ }^{311}$ As an example, she mentions the Corsican autonomy process whose outcome was very much shaped by the excessive number of veto players on the governmental level in 1982, 1991 and 2001.

${ }^{312}$ This type of favourable fragmentation was present in the North-east Indian movements of Naga, Mizo and Bodo.

${ }^{313}$ Ghai et al. (2013), pp. 449-486.

${ }^{314}$ Ghai et al. (2013), pp. 452.
} 
characterized as a liberal democracy ${ }^{315}$ such as: Gagauzia in Moldova, Hong Kong in China, Aceh Darussalam in Indonesia, Bougainville in Papua New-Guinea, Muslim Mindanao in the Philippines or Tatarstan in Russia.

Lapidoth highlights 16 points, which can contribute to a successful autonomy arrangement. Among these, we will find some I have already alluded to above (like the positive, mediating role of the international community) as well as new factors such as the importance of the consent of the minority community that is supposed to be the subject of the newly established autonomy. Moreover, if there is a kinstate to which the given minority of a host country is attached to culturally, than that kinstate should be involved in the autonomy negotiation process (and be able to give its tacit or explicit consent to it); and the arrangement should be mutually beneficial for both the state and the population of the given region. ${ }^{316}$

\subsection{Romanian state}

Earlier I have already alluded to some traits of the Romanian political culture that represent difficulties to be reckoned with, such as: informal mechanisms of decisionmaking that often prevail over formal ones; selective law enforcement; weakness of ruleof-law traditions; high levels of corruption-proneness resulting in the criminalisation of the political-elite and the reproduction of neo-patrimonial political practices; poorly phrased laws generating cacophony in interpretations of legislation; or the general lack of willingness to implement laws regarding minority rights. Nonetheless, from a legal doctrinal point of view, the following general categorization contains options that are theoretically available if state authorities wanted to accommodate minority autonomy claims:

I) Options involving the amendment of the constitution or the adoption of a new one:

a) Federalization: The imaginary line that separates the western civilization from the orthodox world runs right through the middle of Romania. ${ }^{317}$ The line of the Carpathians

\footnotetext{
315 See e.g.: Schulte (2015), pp. 75-84.

316 Lapidoth (1997), pp 199-201.

${ }^{317}$ See Huntington (1996), 258.
} 
separate regions and communities with historically divergent views on shared motivations, social values, beliefs, identities and interpretation of common experiences. ${ }^{318}$ These differences also have an economic spill-over effect in so far as they are reflected in different working morals, differences in financial literacy and economic discipline, traditions and religious beliefs affecting economic performance as well as consumer preferences or disparities in the inclination towards corruption. ${ }^{319}$ In multiethnic polities shaped by such vast regional, historical, cultural and linguistic differences, a federalized state can be considered as an appropriate constitutional structure. This option, however, would most likely come into the fore only if Romania was to unify with the Republic of Moldova, which is not a plausible scenario in the foreseeable future. ${ }^{320}$

b) Transformation into a regionalized state, characterised by asymmetric regionalism, like Spain or Italy: As Asbjørn Eide noted, a process of decentralization is often a "reaction to over-centralization, found unacceptable both because of bureaucratic overload, and for linguistic, cultural or other reasons. In Europe, recent cases are those of Belgium, Italy and Spain." ${ }^{321}$ In terms of Romania, both aspects are relevant. On the one hand, asymmetric regionalism could contribute to tackling governmental bureaucracy and the forms of corruption that can be linked to over-centralization. On the other hand, such regionalization would enable the state to avoid unnecessary inter-ethnic conflicts and create an administrative machinery that is often characterised as one of the most effective ways to ensure the effective participation of national communities in public affairs. ${ }^{322}$ As the Explanatory note of the Lund Recommendations reminds, "experience shows that powers can be divided even with respect to fields of public authority traditionally

\footnotetext{
${ }^{318}$ For a detailed description about the cultural differences in Romania see the findings of Bakacsi et al. (2006).

${ }^{319}$ For more information on culture`s impact on economy in both Romania, as well as in the whole EU see: Dabis (2015), pp.111-132.

${ }^{320}$ Such a unification would first require the settlement of the Transnistrian question between Moldova, Russia and the population of Transnistria. Secondly, the Gagauzian autonomy statute foresees the region's secession from Moldova provided the country's independent status ceases to exist. Gagauzia even organized a consultative referendum on the issue in 2014, where the overwhelming majority opted against the unification with Romania as well against EU membership, and favoured independence and membership in the Russian customs union instead. A third obstacle would be the reluctance of Moldovans to become a part of Romania.

${ }^{321}$ Paragraph 257 of Report no. E/CN.4/Sub.2/1993/34/Add.4 of the Commission on Human Rights of the UN on the Protection of Minorities, available: http://www.refworld.org/pdfid/3b00f4344.pdf, accessed: 2017.02.22.

${ }^{322}$ See e.g. Section III/B of the OSCE's Lund recommendations on the Effective Participation of National Minorities in Public Life.
} 
exercised by central government, including devolved powers of justice (both substantive and procedural) and powers over traditional economies." 323

II) Options not necessarily requiring constitutional amendments. The main responsibility lies with the host country to protect its citizens belonging to a minority. The opportunity to engage in a dialogue with minorities is always open, and the administrative reform that has been on the agenda of Romanian politics for years now is a suitable framework for such a dialogue. The central government could at any time engage in a discussion with the representatives of the Hungarian community in order to elaborate an arrangement that would accommodate their aspirations but left the constitutional framework unchanged. Such a process could contain questions on the distribution of power and further decentralization through organic- or ordinary laws, but it should at least pertain to acknowledging cultural circumstances and aspects of minority protection when drawing the borders of future administrative units in accordance with the international and domestic legal obligations of the country. Pursuant to the provisions of Law 215/2001, and Article 5 of the European Charter of Local Self Government, a local referendum should be conducted to establish the will of the local communities in this regard. It would be perceived as a major step forward if Szeklerland were able to form one unified administrative unit even if it was without special law-making competencies. The historical seats, which are so deeply embedded in Szekler culture, could also be administratively re-established. This option would be short of what is written in the draft statute of autonomy, still it would represent a meaningful step towards recognizing the existence and distinctiveness of Szeklerland; contribute to building mutual trust between Hungarians and Romanians and foster the desecuritization of autonomy aspirations, all of which are key components for establishing a sustainable autonomy arrangement. As outlined in Chapter 4, such an autonomy does not contradict the constitutional order of the country and can be established without having to amend the Constitution.

323 See paragraph 20 of the Explanatory note, available at: http://www.osce.org/hcnm/32240?download=true, accessed: 2017.02.23. 


\subsection{Minority community}

While past events show that external (accession to international organizations) and internal (coalition forming with Hungarian parties) developments can trigger fluctuations in majority rhetoric on minority rights in Romania, this is not the case regarding attitudes towards autonomy. ${ }^{324}$ As we saw in Chapter 2.3, the majority political parties - regardless of their ideological affiliation - remain adamantly opposed to granting either cultural or territorial autonomy. Representative organizations of the Hungarian community are, thus, left without political allies among the majority parties in this regard. Hungarian parties can reach certain concessions if their presence is needed to produce a governing majority in the national parliament. Still, as long as the general opinion of the political elite remains so rejecting, major public demonstrations need to be organized to raise both international and domestic public awareness. Given that the Romanian political elite refuses to engage in a dialogue about autonomy within domestic institutions, proactive presence in international fora is pivotal, which can provide external motivation for Romanian authorities to engage in a dialogue in order to accommodate minority claims.

An aspect, which continuously comes to the fore when mentioning the minority actors of the autonomy struggle is the extent to which they are internally fragmented. Cunnigham mentioned that while unified autonomy movements do not have to face "divide and conquer" tactics of the central government, certain degrees of organizational fragmentation can foster an autonomy deal. As far as Hungarian political parties are concerned, the Dominant party was always DAHR which has gained around $80 \%$ of the valid Hungarian votes since the political transition even when they had smaller contenders (like the Hungarian Civic Party or the Hungarian People's Party of Transylvania, both of which are pro-autonomy parties). ${ }^{325}$ Outside the party-political arena, the most relevant actor is the Szekler National Council, which, unlike DAHR, does not participate in elections and is rather involved in paradiplomacy and the organization of pro-autonomy mass demonstrations. ${ }^{326}$ If we accept Cunningham's findings, we can conclude that this type of fragmentation can potentially foster a moderate form of autonomy arrangement.

\footnotetext{
${ }^{324}$ See finding of Andriescu (2007).

325 Source: Kiss (et. al) (2013), p. 7-8.

${ }^{326}$ A partner organization of SzNC is the Hungarian National Council of Transylvania which has a Transylvanian wide scope of activity and is not narrowed down to Szeklerland.
} 
However, critics of DAHR point out that the party has switched tactics step by step and shifted from the community building- and mobilizing tactics of the nineties to putting an emphasis on the absorption of state resources instead. This in turn allows for a phenomenon called control-cooptation, whereby the central state is able to mitigate minority claims while not giving any concessions in return. ${ }^{327}$ While DAHR was a member of various governments for over 16 years from 1996 onwards, the privileges they managed to obtain (like state investments in Hungarian regions) were due to ad hoc political deals, the cost of which was to abandon claims on institutionalization of ethnic power sharing or the use of international advocacy strategies. ${ }^{328}$ Given that this model reproduces the dominance of the titular nation and the marginalization of the Hungarian community, political parties that profess to represent an autonomist agenda, should sever ties with control cooptation, which allows the central state to transforms a minority representative organization into a channel that mediates and reproduces power asymmetry. ${ }^{329}$ Instead, minority organizations and DAHR in particular should resume and amplify strategies of community-building, international advocacy as well as domestic-public pressure and aim to achieve institutional solutions, as opposed to relying on haphazard political pacts. Such a strategy shift can be based on, and supported by, the overwhelming consensus and unity among Szeklers regarding demands towards territorial autonomy.

\section{$5.3 \quad$ Kin-state}

According to Kardos, "four types of action can be taken by a kin-state in favour of its kin minority: actions in the context of international bodies and mechanisms, actions in cooperation with the home state, actions vis-à-vis other states, and domestic legislation on

\footnotetext{
${ }^{327}$ Control-cooptation referrers to the process of neutralizing or overcoming the influence potential of a certain group (in this case a party representing a minority community) through assimilation into existing power-structures.

${ }^{328}$ In 2013 PM Victor Ponta made specific references to control-cooptation when he emphasized the importance of preventing the "radicalization" of Hungarian self-government claims by allowing DAHR into the government. See: Kiss (2015), p. 55.

${ }^{329}$ It is worth mentioning that the shear existence of control cooptation within the Romanian model calls into question the rationale of having a unified organizational system for minority protection.
} 
the relationship with its kin minority". ${ }^{330}$ In this context, there are two most salient forms of Hungarian kin-state activity. Firstly, it is important to have good neighbourly relations built on mutual trust between the kin-state and the host country. It is hard to imagine that Romania would grant autonomy to a minority whose kin-state they are suspicious of. Good relations and trust between Romania and Hungary can therefore be seen as a prerequisite for Szekler autonomy. Secondly, while some of the support that Hungary has so far granted for its kinspeople abroad stirred some controversy in the host countries (like the Status Law in the late nineties), financial and cultural support was much less contentious and has meant an important form of support that assisted minority communities in reproducing their societies. The maintenance of minority identity is a crucial question due to the rapid demographic decline Hungarian minorities have been suffering for many decades. ${ }^{331}$ Such kin-state aid policies are not illegitimate or illegal given that Hungary concluded a series of bilateral treaties on good neighbourly relations and cooperation with surrounding states. Among others, these treaties contain reciprocal obligations for parties to protect and promote the existence and identity of minorities and obliges parties to settle all their disputes concerning the interpretation or implementation of this Treaty through direct consultations and negotiations or based on an international multilateral treaty on peaceful settlement of disputes both countries are parties to. Due to these, Hungary has a treaty-based, mutually agreed-upon opportunity to be involved in the management of minority affairs of neighbouring countries including Romania. Given the general reluctance of the international community as a whole to address the yet unresolved issues of traditional minorities, the kinstate activity of Hungary will continue to be an important factor in helping minority Hungarians to maintain and reproduce their societies, let their voices be heard by the international public opinion, initiate a dialogue with the host countries on their problems and aspirations and to negotiate beneficial economic deals and promote cross-border development programs.

\footnotetext{
${ }^{330} \operatorname{Kardos}(2006)$, p. 130

${ }^{331}$ Csángó Hungarian, for example, is already listed by UNESCO as one of the severely endangered languages of Europe.
} 


\subsection{International community}

The limited willingness of the main human rights/minority rights forum of Europe (the CoE) to interfere with minority affairs became obvious by 1993 at the latest. Had the Committee of Ministers of the CoE adopted Recommendation 1201 (1993), Europe would have an additional protocol on the rights of minorities to the European Convention on Human Rights which would be enforceable before the European Court of Human Rights. Not even an armed conflict, as violent as the Yugoslav wars, proved to be enough of an incentive for European states to create a general legal framework through which an external actor would have been entitled to make legally binding decisions regarding minority protection. Even so, Article 1 of FCPNM stipulates that the protection of national minorities and of the rights and freedoms of persons belonging to those minorities forms an integral part of the international protection of human rights, and as such falls within the scope of international co-operation. Consequently, while the responsibility to implement measures of minority protection lies primarily with the respective states, the question itself is not merely an issue of any state's internal affairs. With this in mind, the importance of international organizations is mainly to provide platforms to develop the global or regional legal regimes of minority protection and to motivate states and within the given possibilities hold them accountable for the implementation of at least those international documents that were ratified by them. I have already mentioned the importance of the active involvement of other states and international institutions in autonomy arrangements. ${ }^{332}$ What can be added is that the international community can also foster the durability of autonomy arrangements as seen in the case of both South-Tyrol and the Åland Islands. Moreover, drawing on the experiences of this latter region, Hannikainen even asked the question why not authorize an international organ to work for the creation of regional autonomies in States? ${ }^{333}$ In the case of the Åland Island, the League of Nations actively participated in the formulation of the regional autonomy in close cooperation with both the minority community and its host country, who were both able to communicate their viewpoints to the League Council, and if these pertained to legal questions, the Permanent Court of International Justice could have been consulted. More importantly, the Ålanders had the opportunity to turn to

\footnotetext{
${ }^{332}$ Ghai et al (2013), p. 452

${ }^{333}$ Hannikainen (1998), p. 95
} 
the League of Nations, as the external guarantor agency, in the event of Finland breeching its commitments.

As we saw earlier, Romanian constitutional culture was heavily influenced by foreign models. Constitutional transplants following mostly the French and the Belgian constitutions were present in many cases. After the political transition of 1989, the EuroAtlantic integration provided for a set of different external requirements from both Strasbourg and Brussels, some of which even entailed the amendment of the constitution. International influence proved to be a strong factor in shaping both the norms and the mentalities specific to the Romanian legal system and constitutional culture. In fact, the historical overview presented in chapter 1.5 showed that the active involvement of external forces, especially state powers, was always needed in some form to develop the domestic circumstances of minority protection in Romania. Even though there appears to be a sufficiently diminishing readiness from the side of the international community to actively engage in resolving issues of traditional national communities of Europe, especially since the migration/refugee crisis started to unfold as of 2015 , the mechanisms of the Council of Europe and the European Union, along with the involvement of foreign states could still play a salient role in fostering to improve autonomy related practices and legislation in Romania. 


\section{Annexes}

Table 1 - Demographic trends of Hungarian minority communities living in countries adjacent to Hungary (1989-2011)

\begin{tabular}{|l|c|c|c|c|c|}
\hline Country & $1989-1992$ & $2001-2002$ & $\%$ & 2011 & $\%$ \\
\hline Austria & 33.459 & 40.583 & 21.3 & $\sim 60.000$ & 47.8 \\
\hline Croatia & 22.355 & 16.595 & -25.8 & 14.048 & -15.3 \\
\hline Romania & 1.624 .959 & 1.434 .377 & -11.7 & 1.268 .444 & -11.6 \\
\hline Serbia & 344.147 & 293.299 & -14.8 & 251.136 & -14.4 \\
\hline Slovakia & 567.296 & 520.528 & -8.2 & 458.467 & -11.9 \\
\hline Slovenia & 8.503 & 6.243 & -26.6 & $\sim 5000$ & -19.9 \\
\hline Ukraine & 155.711 & 151.516 & -2.7 & $\sim 141.000$ & -6.9 \\
\hline Total & 2.756 .430 & 2.463 .141 & -10.61 & 2.198 .095 & -10.76 \\
\hline
\end{tabular}

Source: Répás (ed.) (2013), p. 24.

Figure 1 - Administrative borders of the Austro-Hungarian Empire

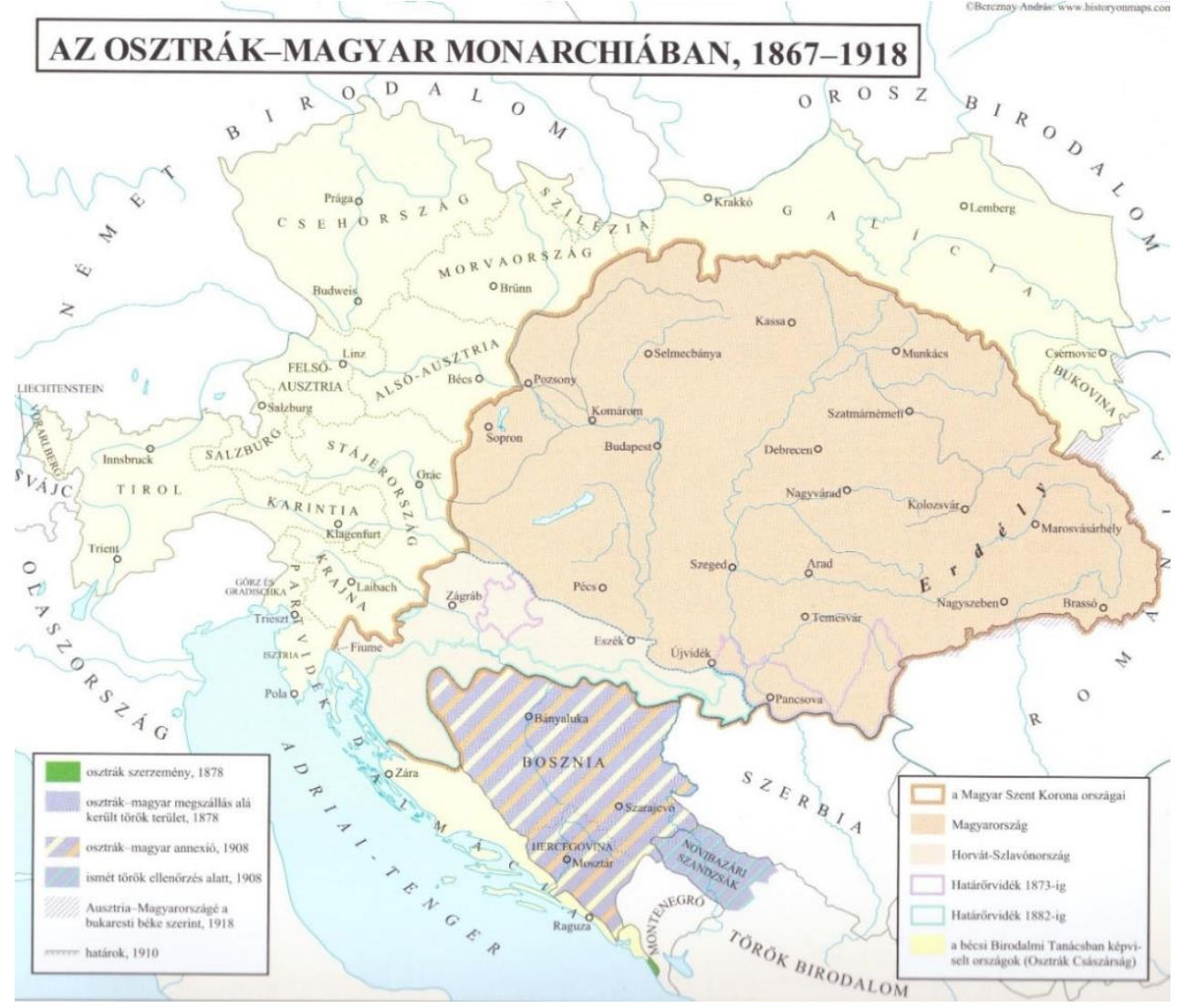

Source: Bereznay (2011), p. 173. 
Figure 2 - Territorial changes due to the 1st, and 2nd Vienna Arbitrations in 1938, and 1940

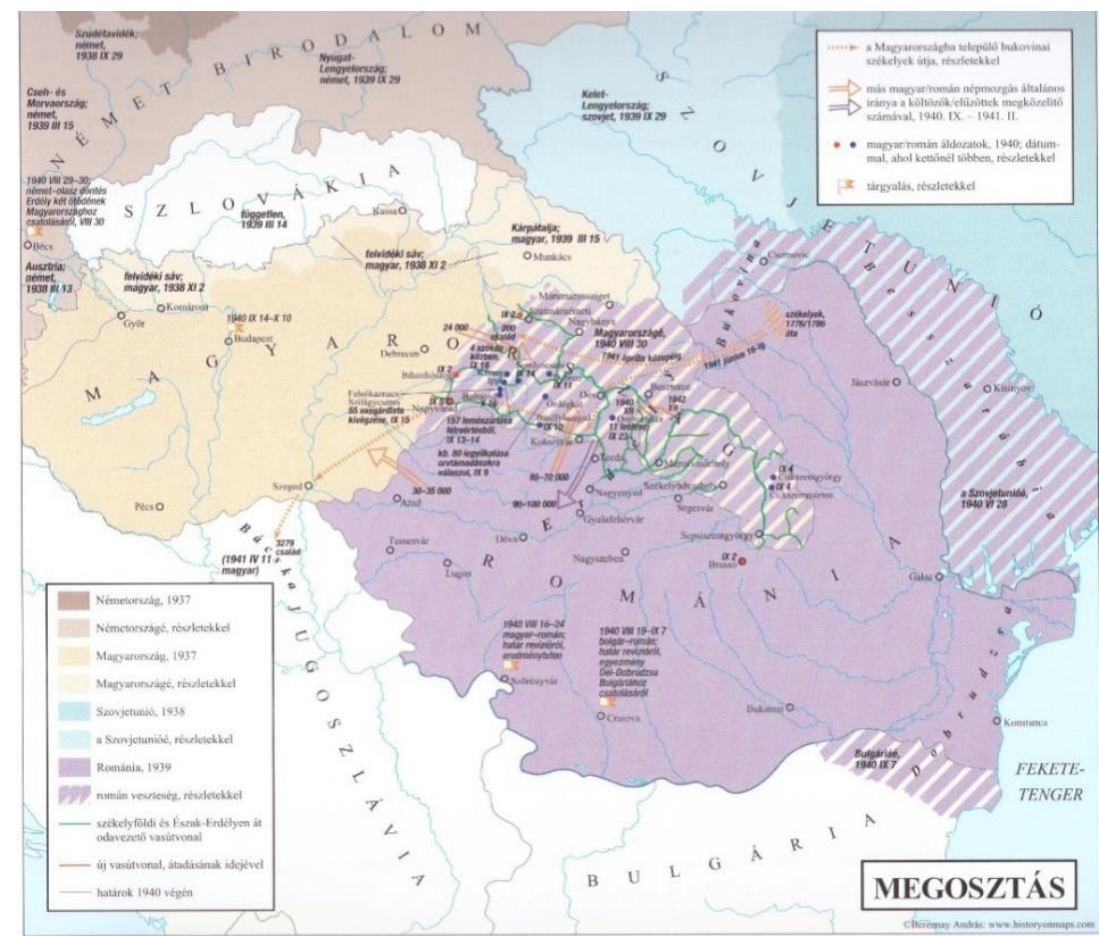

Source: Bereznay (2011), p. 195.

Figure 3 - Changing borders of the Hungarian Autonomous Province in communist Romania

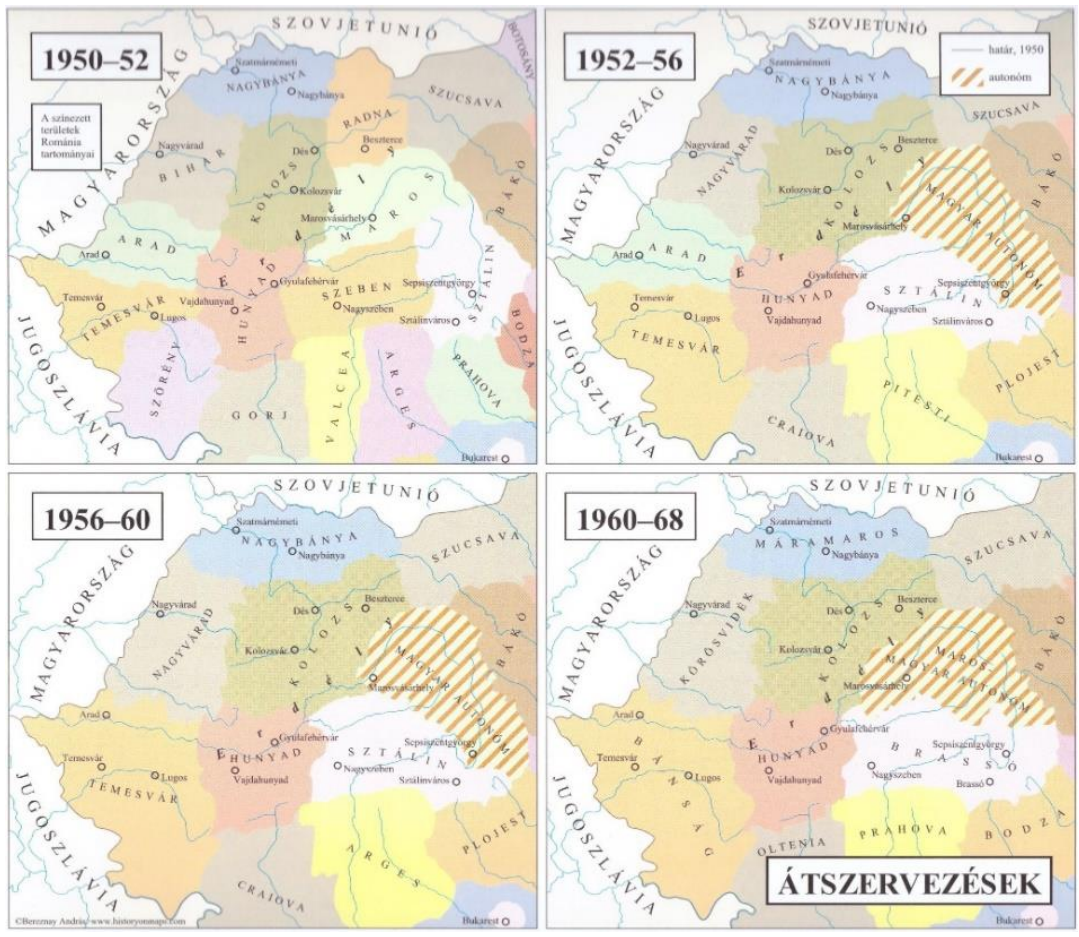

Source: Bereznay (2011), p. 205. 
Figure 4 - Ethnic distribution of Transylvania (1910-1977)

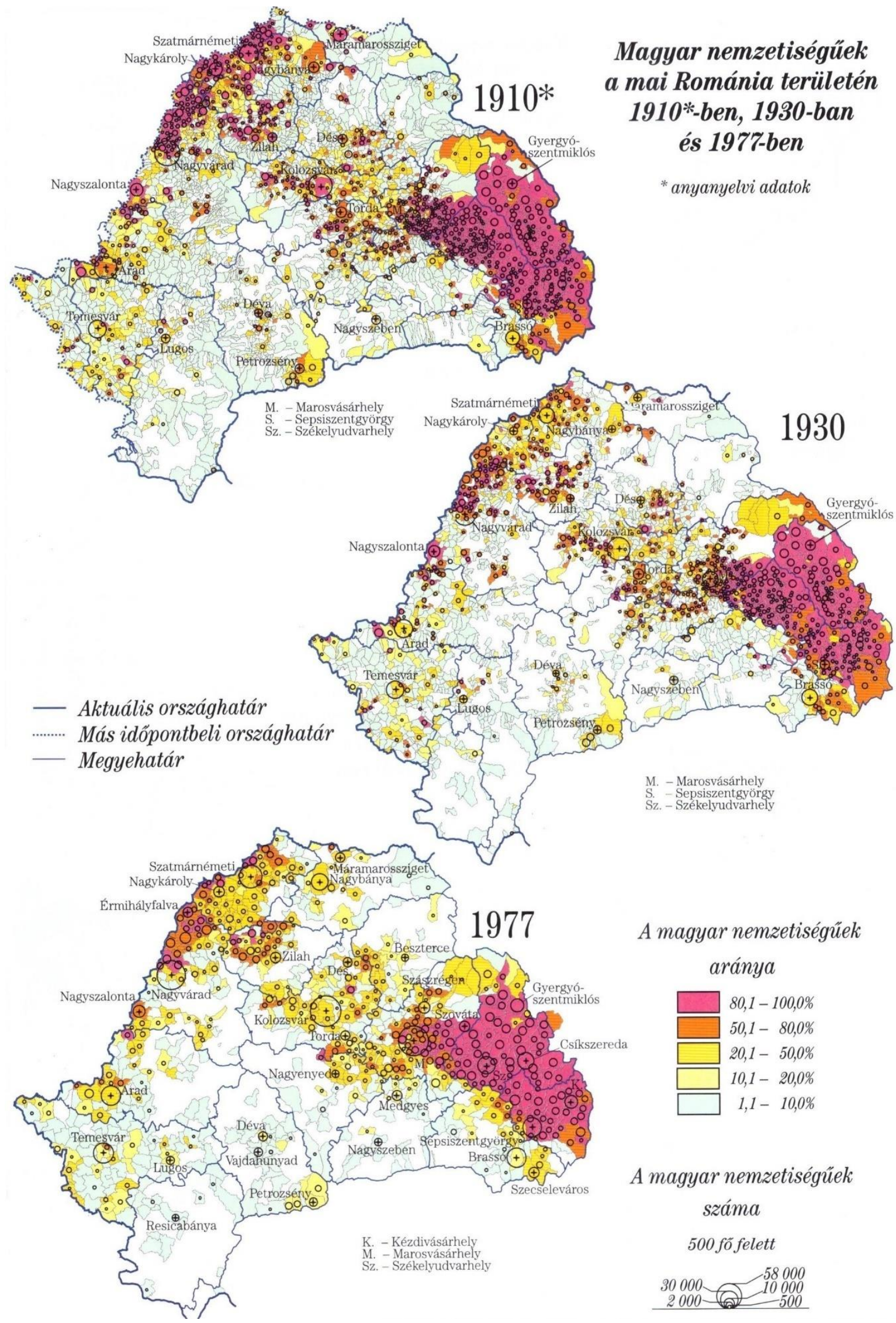

Source: Bárdi et al. (2008), p. 504. 
Figure 5 - Ethnic distribution of Transylvania (2002)

\section{Magyar nemzetiségüek a mai Románia területén 2002-ben}

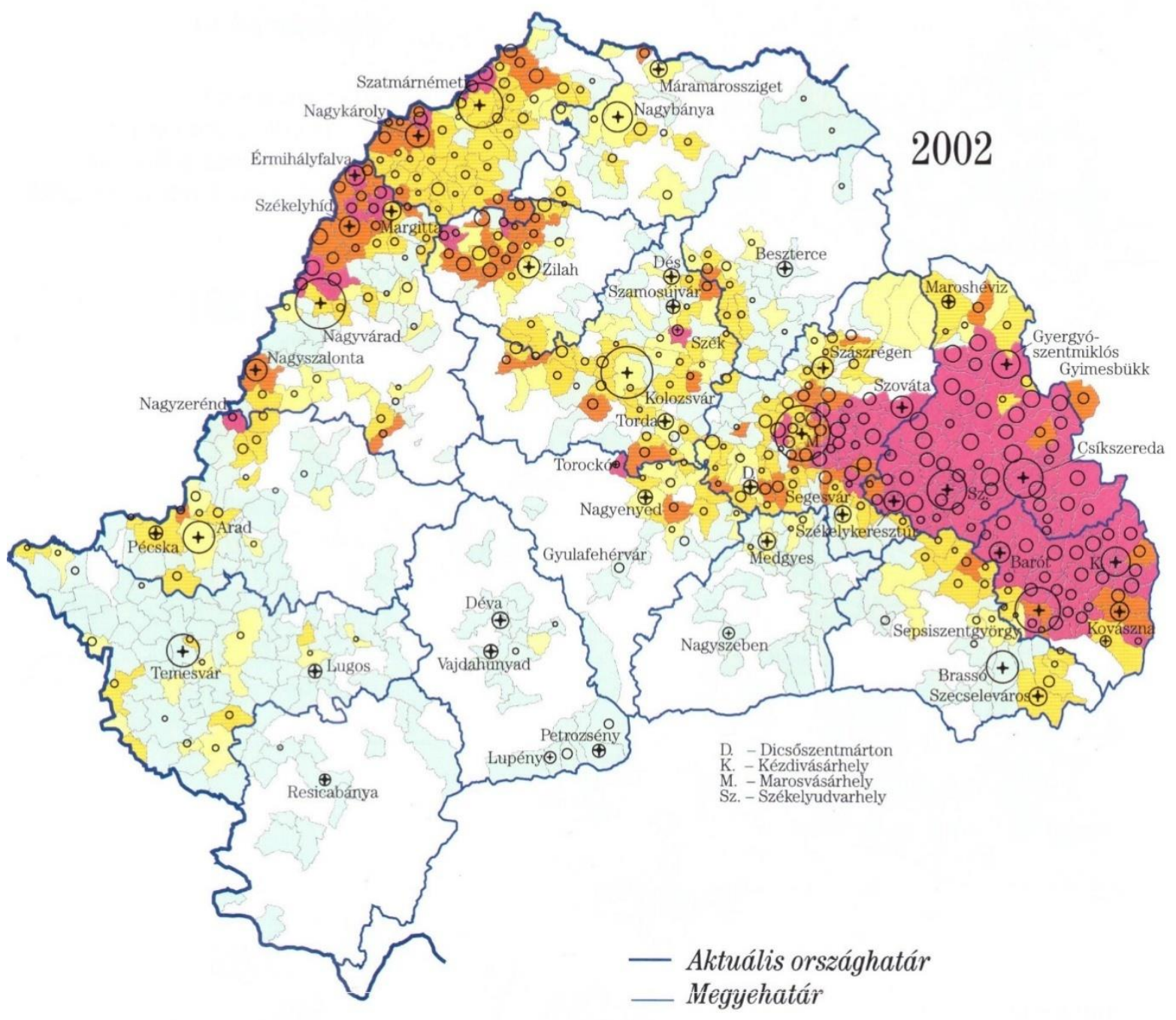

A magyar nemzetiségüek

aránya

száma

$80,1-100,0 \%$

$50,1-80,0 \%$

$20,1-50,0 \%$

500 fó felett

$10,1-20,0 \%$

$1,1-10,0 \%$

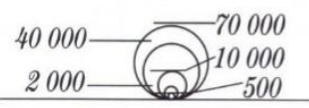

Source: Bárdi et al. (2008), p. 505. 


\section{Bibliography}

Åkermark, Sia Spiliopoulou (2013): Internal Self-Determination and the Role of Territorial Autonomy as a Tool for the Resolution of Ethno-Political Disputes. In: International Journal on Minority and Group Rights, Volume 20, Issue 1, pp. 525.

DOI: $\underline{10.1163 / 15718115-02001002}$

Andreescu, Liviu (2007): The Construction of Orthodox Churches in Post-Communist Romania. In: Europe-Asia Studies, Vol. 59, No. 3 (May, 2007). Glasgow: University of Glasgow, pp. 451-480.

Andriescu, Monica (2007): Rhetorical Patterns on Minority Language and Education Rights in Post-Communist Romania: Finding the Middle Ground (1996 - 2004). CEU Political Science Journal Vol. 2, Issue 4. Budapest: CEU.

Arday Lajos (2010): Kisebbségek, kisebbség politikák Kelet-Közép Európában. Available: http://www.grotius.hu/doc/pub/KHXPKJ/dke_02_ma_kk_arday.pdf, accessed: 2015.04.25.

Arzoz, Xabier (2012): New Developments in Spanish Federalism. In: Dans L' Europe en Formation 2012/1 (n³63), pp. 179 - 188.

DOI: 10.3917/eufor.363.0179

Bakacsi Gyula et al. (2006): Final report on the results of GLOBE-Romania project. Manuscript.

Bakk Miklós (2004): Az autonómia-tervek két szakasza Erdélyben 1989 után. In: Magyar Kisebbség, IX évf. 2004. 1-2 (31-32.) sz. Kolozsvár: Jakabffy Elemér Alapítvány.

Bakk Miklós (2010): Politikai közösség és identitás az alkotmányban. In: Magyar Kisebbség XV. évf. 2010. 1-2. (55-56.) sz. Kolozsvár: Jakabffy Elemér Alapítvány, p.15-44.

Bárdi Nándor (2004): Javaslatok, modellek az erdélyi kérdés kezelésére - A Magyar elképzelések 1918-1940. In: Konfliktusok és kezelésük Közép-Európában, TLA, 
pp. 137-180. Ua. Magyar Kisebbség 2004. 1-2. sz., pp. 329-376. Kolozsvár: Jakabffy Elemér Alapítvány.

Bárdi Nándor \& Fedinec Csilla \& Szarka László (eds.) (2008): Kisebbségi Magyar közösségek a 20. században. Budapest: Gondolat - MTA Etnikai- Nemzeti Kisebbségkutató Intézet.

Benedikter, Thomas (2007): The World's working regional autonomies - an introduction and comparative analysis. London, New York, Delhi: Anthem Critical Studies.

Bereznay András (2011): Erdély történelmi atlasza. Somorja: Méry Ratio.

Bernhardt, Rudolf (1981): Federalism and Autonomy. In: Dinšțein, Yôrām (ed.): Models of Autonomy. New Brunswick, New Jersey: Transaction Books, Rutgers.

Bolleyer, Nicole \& Swenden, Wilfried \& McEwen, Nicola (2014): A theoretical perspective on multi-level systems in Europe: Constitutional power and partisan conflict. In: Comparative European Politics (2014) 12. University of Copenhagen, Denmark - New York University, USA: Palgrave Macmillan, pp. 367-383.

DOI: $10.1057 /$ cep. 2014.18

Bonell, Lukas \& Winkler, Ivo (2006): Südtirols Autonomie. Bozen: Herausgegeben von der Südtiroler Landesregierung.

Bottoni, Stefano (2008): Sztálin a Székelyeknél. A Magyar Autonóm Tartomány története. (1952-1960). Csíkszereda: Pro-Print Könyvkiadó.

Boyron, Sophie (2013): The Constitution of France: A Contextual Analysis (Constitutional Systems of the World). Oxford: Hart Publishing.

Brubaker, Rogers (1996): National minorities, nationalizing states, and external national homelands in the New Europe. In: Nationalism reframed: Nationhood and the national question in the New Europe. Cambridge: Cambridge University Press, pp. 55-76.

DOI: $\underline{\text { http://dx.doi.org/10.1017/CBO9780511558764 }}$ 
Brunner, Georg \& Küpper, Herbert (2004): Európai autonómia-megoldások: A kisebbségi önkormányzatok autonómia-modelljeinek tipológiája, In: Magyar Kisebbség. 2004. 1-2. sz. Kolozsvár: JakabffyElemérAlapítvány, pp. 466-498.

Cassese, Antonio (1995): Self-Determination of Peoples: A Legal Reappraisal. Cambridge, New York: Cambridge University Press.

Committee on Legal Affairs and Human Rights of the Council of Europe (2005): Doc. 10762 - The concept of "nation". Strasbourg: Parliamentary Assembly of the Council of Europe.

Constitutional Court of Romania (2014): Decision Nr. 80 of 16.02.2014, on the legislative proposal on the revision of the Constitution of Romania. Published in the Official Journal of Romania (No. 246) on 07.04.2014, available: http://www.ccr.ro/files/products/Decizie_80_2014.pdf, accessed: 2015.03.27.

Cornell, Svante E. (2002): Autonomy as a Source of Conflict: Caucasian Conflicts in Theoretical Perspective. In: World Politics, 54, pp. 245-276.

DOI: $10.1353 /$ wp.2002.0002

Cunningham, Kathleen Gallagher (2007): Divided and Conquered: Why States and Selfdetermination Groups Fail in Bargaining Over Autonomy. San Diego: University of California Electronic Theses and Dissertations.

Dabis Attila (2015): Reform of the regional policy, and the sustainability of cultural diversity in the EU. In: Prof. Tibor Palánkai (ed): Economic policy alternatives and social models. ISES Studies on European Integration, Issue 5., pp. 111-132.

Dale, Scott Peter (2015): The American Deep State: Wall Street, Big Oil, and the Attack on U.S. Democracy. Lanham, MD: Rowman and Littlefield.

Daftary, Farimah (2004): Insular autonomy; a framework for conflict resolution? Corsica and the Åland-islands. In: Schenker, Ulrich Wolff, Stefan (eds.): Managing and Settling Ethnic Conflicts: Perspectives on Successes and Failures in Europe, Africa, and Asia. New York: Palgrave Macmillan.

Dawn, Oliver \& Fusaro, Carlo (2011): How Constitutions Change: A Comparative Study. Oxford: Hart Publishing. 
Directia Centrala de Statistica - Directia Regionala de Statistica (1960): Anuarul Statistic al Regiunii Autonome Maghiare, 1960 / A Magyar Autonómtartomány Statisztikai Évkönyve. Central Directorate of Statistics - Regional Directorate of Statistics: Bucharest.

European Parliament (2015): The principle of subsidiarity. In: Fact Sheets on the European Union. Luxembourg: Office for Official Publications of the European Communities.

Available: http://www.europarl.europa.eu/ftu/pdf/en/FTU_1.2.2.pdf, accessed: 2015.10.08.

Emich Gusztáv \& Edvi,Illés Aladár \& Halász,Albert (eds.) (1920): Magyarország Gazdasági Térképekben - 1920 / The Economies of Hungary In Maps - 1920. Első reprint kiadás. Budapest: Szabadkéz Kft.

Ferrari, Paolo (ed.) (2009): Südtirol Handbuch 27. Überarbeitete Auflage. Bozen: Südtiroler Landesregierung.

Finlands Riksdag (1920): Riksdagen Protokoll i Sammandrag. Helsingfors: Statsrådets Tryckeri.

Friend, Julius W. (2012): Stateless Nations: Western European Regional Nationalisms and the Old Nations. Houndsmills: Palgrave McMillan

Ghai, Yash (2011): Ålands autonomy in comparative perspective. In: Åkermark, Sia Spiliopoulou (ed.): The Aland Example and Its Components - Relevance for International Conflict Resolution. Mariehamn: The Åland Islands Peace Institute

Ghai, Yash \& Woodman, Sophia (2013): Comparative perspectives on institutional frameworks for autonomy. Ghai, Yash\& Woodman, Sophia (eds.): Practising self-government. A comparative Study of Autonomous Regions. Cambridge: Cambridge University Press, pp. 449-486.

DOI: http://dx.doi.org/10.1017/CBO9781139088206

Ghai, Yash (2013): Introduction: nature and origins of autonomy. In: Ghai, Yash\& Woodman, Sophia (eds.): Practising self-government. A comparative Study of Autonomous Regions. Cambridge: Cambridge University Press, pp. 1-31.

DOI: http://dx.doi.org/10.1017/CBO9781139088206 
Government of Finland (2009): Report of the Government on the application of language legislation. Oikeusministerio: Helsinki. Available: http://www.oikeusministerio.fi/material/attachments/om/julkaisut/6FiopvJGh/Ki elikertomusENG_060432009_netti.pdf, accessed: 2017. 02. 21.

Guibernau, Montserrat (2006): National identity, devolution and secession in Canada, Britain and Spain. In: Nations and Nationalism 12, no. 1 (2006). New Jersey: Blackwell Publishing Ltd., pp. 51-76.

DOI: $10.1111 /$ j.1469-8129.2005.00230.x

Guțan, Manuel (2013a): The Challenges of the Romanian Constitutional Tradition I. Between Ideological Transplant and Institutional Metamorphoses. In: 25 Journal of Constitutional History, pp. 223-252.

Guțan, Manuel (2013b): The Challenges of the Romanian Constitutional Tradition II. Between Constitutional Transplant and (Failed) Cultural Engineering. In: 26 Journal of Constitutional History, pp. 217-241.

Henders, Susan J. (2010): Territoriality, Asymmetry, and Autonomy - Catalonia, Corsica, Hong Kong, and Tibet. Palgrave Macmillan

DOI: $10.1057 / 9780230105829$

Ibarra, Pedro \& Irujo, Xabier (Eds.) (2011): Basque Political Systems. University of Nevada, Reno: Center for Basque Studies.

Hannikainen, Lauri (1988): Peremptory norms in international law. Historical development, Criterea, Present Status. Helsinki: Finnish Lawyers` Publishing Company.

Hannikainen, Lauri (1997): The International Legal Basis of the Autonomy and Swedish Character of the Åland Islands. In: Hannikainen, Lauri \& Horn, Frank (eds.) Autonomy and Demilitarisation in International Law: The Aland Islands in a Changing Europe. The Hague: Kluwer Law International.

Hannikainen, Lauri (1998): Self-determination and autonomy in international law. In: Suksi, Markku (ed.): Autonomy: applications and implications. The Hague; Boston: Kluwer Law International, pp. 79-95. 
Hannum, Hurst (1996): Autonomy, Sovereignty, and Self-Determination. The Accommodation of Conflicting Rights, Revised Edition. Philadelphia: University of Pennsylvania Press.

Hannum, Hurst \& Lillich, Richard B. (1981): The Concept of Autonomy in International Law. In: American Journal of International Law 74 (4), Oct 80. Washington DC: American Society of International Law, pp. 858-889.

Heintze, Hans-Joachim (1998): On the legal understanding of autonomy. In: Suksi, Markku (ed.): Autonomy: applications and implications. The Hague; Boston: Kluwer Law International, pp. 6-32.

Hepburn, Eve (2014): Forging autonomy in a unitary state: The Åland Islands in Finland, In: Comparative European Politics (2014) 12. University of Copenhagen, Denmark - New York University, USA: Palgrave Macmillan, pp. 468-487.

DOI: $10.1057 /$ cep.2014.10

Himsworth, Chris (2013): The Autonomy of Devolved Scotland. In: Ghai, Yash \& Woodman, Sophia (eds.): Practising self-government. A comparative Study of Autonomous Regions. Cambridge: Cambridge University Press, 349-382.

DOI: http://dx.doi.org/10.1017/CBO9781139088206

Huntington, Samuel P. (1996): The Clash of Civilizations and the Remaking of World Order. [First Edition]. London: Simon \& Schuster.

Kardos Gábor (2006): Role for the Kin-states? In: Osamu Ieda ed.: Beyond Sovereignty: From Status Law to Transnational Citizenship? Hokkaido: Slavic Research Center, pp. 127-137.

Kardos Gábor (2015): Fear of Autonomy for Minorities. In: Láncos Petra Lea \& Varga Réka \& Molnár Tamás \& Szabó Marcel (eds): Hungarian Yearbook of International Law and European Law 2014. The Hague: Eleven International Publishing, pp. 35-43.

Kincses Elöd (1990): Marosvásárhely fekete márciusa. Budapest: Püski.

Kiss Tamás \& Barna Gergő \& Székely István Gergő (2013): A társadalomépítéstől a klientúra-építésig. Az RMDSZ és a magyar választók közötti kapcsolódás 
átalakulása. In: Magyar Kisebbség 68. sz. = 18. évf. (2013.) 2. sz., pp. 740.Kolozsvár: Jakabffy Elemér Alapítvány.

Kiss Tamás (2015): Marginalizáció, etnikai párhuzamosság és aszimmetrikus akkomodáció. Az erdélyi magyar közösséget érintő társadalmi és politikai folyamatok. In: Magyar Kisebbség. XX. évf. 12. (75-76.) sz.. pp. 30-64. Kolozsvár: Jakabffy Elemér Alapítvány.

Kocsis Károly (2013): Historical Predecessors and Current Geographical Possibilities of Ethnic Based Territorial Autonomies in the Carpathian Basin. In: Autonomies in Europe: Solutions and Challenges. Budapest: Nemzetpolitikai Kutatóintezet, L`Harmattan.

Krasner, Stephen D. (1999): Sovereignty: Organized Hypocrisy. Princeton, NJ: Princeton University.

DOI: $10.2307 / 2657807$

Lapidoth, Ruth (1997): Autonomy - Flexible Solutions to Ethnic Conflicts. Washington D.C.: US Institute of Peace Press.

DOI: $10.2307 / 2555279$

Larsen, Bárður \& á Rógvi, Kári (2012): A New Faroese Constitution? - Faroe Islands between Parliamentary Sovereignty and Sub-Sovereign Constitutionalism, between Statutory Positivism and Pragmatic Reasoning. In: The Yearbook of Polar Law - Vol IV. Issue 1., pp. 341-363.

DOI: $10.1163 / 22116427-91000097$

Lauterpacht, Hersch (1958): Some observations on the Prohibition of 'Non Liquet' and the completeness of the legal order. In: F. M. van Asbeck (ed.): Symbolae Verzijl: Présentées au Prof J.H.W. Verzijl, à l'occasion de son LXX-ième anniversaire. The Hague: Nijhoff, pp. 196-221.

Légaré, André \& Suksi, Markku (2008): Rethinking the Forms of Autonomy at the Dawn of the 21st Century. In: International Journal on Minority and Group Rights, Volume 15, Issue 2, pp. 143 - 155. Leiden: Brill Publishing.

DOI: $\underline{10.1163 / 157181108 X 332578}$ 
Legislative Council of the Parliament of Romania (2004): Opinion Nr. 102 of 2004 on the rejection of the Draft Law on the Autonomous Status of Szeklerland. Bucharest: Parliament of Romania. Romanian version available: http://sznt.sic.hu/ro/index.php?option= com_content $\& v i e w=\operatorname{article} \& i d=171 \% 3 \mathrm{~A}$ aviz-referitor-la-propunerea-legislativ-privind-statutul-de-autonomie-al-inutuluisecuiesc\&catid=10\%3Astatutum\&Itemid $=14 \&$ lang=ro, Hungarian version available: http://sznt.sic.hu/hu-sic/index.php?option=com_content\&view=article $\underline{\text { \&id=171\%3Aszekelyfoeld-autonomia-statutuma-toerveny kezdemenyezesre- }}$ vonatkozo-velemenyezes\&catid=10\%3Astatutum\&Itemid=14\&lang =fa, accessed: 2017.04.04.

Leyland, Peter (2012): The Constitution of the United Kingdom: a Contextual Analysis. (Constitutional Systems of the World). Oxford: U.K. Hart.

Mackinder, Halford John (1904): The Geographical Pivot of History. In: The Geographical Journal, Vol. 23, No. 4 (Apr, 1904). London: Royal Geographical Society.

DOI: $10.1111 / j .0016-7398.2004 .00132 . x$

Miklósné Zakar Andrea (2010): Interetnikus értelmiségi diskurzusok az erdélyi autonómiáról. Doktori Értekezés. Győr: Széchenyi István Tudományegyetem.

Parliament of Romania (1991): The Constitution of Romania, available: http://www.cdep.ro/pls/dic/site.page?id=371, accessed: 2015.03.27.

Peterlini, Oskar (2013): Foundations and Institutions of South Tyrol's autonomy. In: Ghai, Yash \& Woodman, Sophia (eds.): Practising self-government. A comparative Study of Autonomous Regions. Cambridge: Cambridge University Press, pp. 118-162.

DOI: $\underline{\text { http://dx.doi.org/10.1017/CBO9781139088206 }}$

Radbruch, Gustave (1956): Rechtsphilosophie [5. Auflage]. Stuttgart: Koehler

Répás Zsuzsanna (ed.) (2013): Magyar Nemzetpolitika - A Nemzetpolitika Stratégiai Kerete. Budapest: Magyar Közlöny Lap- és Könyvkiadó Kft. 
Romániai Magyar Demokrata Szövetség (1993): Törvény a nemzeti kisebbségekröl és autonóm közösségekről. In: Magyar Kisebbség III. Évf. - 1997. 1-2. (7-8.) szám. Kolozsvár: Jakabffy Elemér Alapítvány, pp. 314-329.

Rosas, Allan (1993): Internal Self-Determination. in: Tomuschat, Christian (Ed.): Modern law and self-determination. Boston: Martinus Nijhoff Publishers, pp. 225-252.

Salat Levente \& Constantin, Sergiu \& Osipov, Alexander \& Székely István Gergő (eds.) (2014): Autonomy Arrangements around the World: A Collection of Well and Lesser-Known Cases. Kolozsvár/Cluj-Napoca: Romanian Institute for Research on National Minorities.

Schulte, Felix (2015): Conflict Regulation through Self-Rule - Success Factors of Territorial Autonomy Systems, In: Report from the Aland Islands Peace Institute, Nr. $\quad 1, \quad$ April 2015., available: http://www.peace.ax/images/FINAL_Report_1_2015_FS_online.pdf, accessed: 2016.04.25.

Selejan-Gutan, Bianca (2016): The Constitution of Romania: A Contextual Analysis (Constitutional Systems of the World). Oxford: Hart Publishing.

Shaykhutdinov, Renat (2010): Give peace a chance: Nonviolent protest and the creation of territorial autonomy arrangements. In: Journal of Peace Research 47(2), pp. 179-191.

DOI: $10.1177 / 0022343309353109$

Smith, David J \& Hiden, John (2012): Ethnic diversity and the Nation State. National cultural autonomy revisited. London and New York: Routledge.

Stone, Julius (1964): Legal System and Lawyers' Reasonings. Stanford: Stanford University Press

Suksi, Markku (1993): Bringing in the People: A Comparison of Constitutional Forms and Practices of the Referendum. Dordrech: Martinus Nijhoff.

Suksi, Markku (ed.) (1998): On the Entrenchment of Autonomy, In: Suksi, Markku ed. Autonomy: applications and implications. The Hague; Boston: Kluwer Law International, pp. 151-171. 
Suksi, Markku (1999): On the Constitutional Features of Estonia. Turku/Åbo: Åbo Akademis Tryckeri.

Suksi, Markku (2011): Sub-State Governance through Territorial Autonomy: A Comparative Study in Constitutional Law of Powers. Berlin Heidelberg: Springer Verlag.

DOI: $10.1007 / 978-3-642-20048-9$

Szekler National Council (2009): The Autonomy Statute of Szeklerland. Sepsiszentgyörgy: T3 Kiadó.

Stanomir, Ioan et al (2010): A romániai politikai és alkotmányos rendszert elemző államfői bizottság jelentése - a jogállam megerősítése érdekében. In: Magyar Kisebbség, $X V$. évf. 2010. 1-2. (55-56.) sz. Kolozsvár: Jakabffy Elemér Alapítvány, pp. 9-89.

Stepan, Alfred \& Linz, Juan \& Yadav, Yogendra (2011): Crafting State-Nations: India and Other Multinational Democracies. Baltimore, MD: Johns Hopkins University Press

DOI: http://dx.doi.org/10.1080/00358533.2011.609701

Szalayné Sándor Erzsébet (2003): A kisebbségvédelem nemzetközi jogi intézményrendszere a 20. században. Budapest: MTA - KKI.

Thompson, Wayne C. (1998): Citizenship and Borders: Legacies of Soviet Empire in Estonia. In: Journal of Baltic Studies, 29:2, Summer 1998, pp. 109-134.

DOI: $10.1080 / 01629779800000021$

Tkacik, Michael (2008): Characteristics of Forms of Autonomy. In: International Journal On Minority \& Group Rights 15, no. 2/3 (June 2008). Nacogdoches: Stephen F. Austin State University SFA Scholar Works, pp. 369-401.

DOI: $10.1163 / 157181108 X 332668$

Tomuschat, Christian (1992): Democratic Pluralism: The Right to Political Opposition. In: Rosas, Allan \& Helgesen, Jan (eds): The strenght of diversity and pluralist democracy. Dordrecht: Nijhoff, pp. 27-48. 
Tóth Norbert (2014): A kisebbségi területi autonómia elmélete és gyakorlata: Nemzetközi jogi és összehasonlitó jogi analizis. Budapest: L'Harmattan.

Tierney, Stephen (2014): Flexible Accommodation: Another Case of British Exceptionalism? In: Lluch Jaime (ed.): Constitutionalism and the Politics of Accommodation in Multinational Democracies. New York, Basingstoke: Palgrave Macmillan, pp. 159-179.

Turpin, Colin \& Tomkins, Adam (2011): British government (7th ed.). Cambridge: Cambridge University Press.

DOI: http://dx.doi.org/10.1017/CBO9781139060738

Watts, Ronald L. (2008): Comparing federal systems. London: McGill-Queen's University Press.

Weber, Max (1922): Wirtschaft und Gesellschaft. Tübingen: Mohr.

DOI: 10.1007/978-3-531-90400-9_129

Weller, Marc \& Nobbs, Katherine (ed.) (2010): Asymmetric autonomy and the settlement of ethnic conflicts. Philadelphia: University of Pennsylvania Press.

Woelk, Jens \& Palermo, Francesco \& Marko, Joseph (eds.) (2008): Tolerance through law - Self-governance and group rights in South Tyrol. Bozen: European Academy of Bolzano-EURAC.

Wolff, S. (2013): Conflict Management in Divided Societies: The Many Uses of Territorial Self-governance. In: International Journal on Minority and Group Rights, $20 \quad$ (2013) 1 , pp. 27-50; available at http://booksandjournals.brillonline.com/content/10.1163/15718115-02001003, accessed: 2015.07.16.

DOI: $\underline{10.1163 / 15718115-02001003}$ 


\section{Publications by the Author on the Topic}

\section{Articles in Refereed Journals in Hungarian}

Dabis Attila (2016): Az Åland-szigetek autonómiájának felülvizsgálatáról. In: Századvég 82. 2016/4., pp. 113-123.

Dabis Attila (2016): Miért sikeresebbek a svédek mint a számik? In: Kisebbségi Szemle 2016/1., pp. 89-107.

Dabis Attila (2013): A skót szecesszió dilemmái. In: Kisebbségkutatás - 22. évf. 2. szám, pp. 29-66.

Dabis Attila (2012): Dél-Tirol Autonómia-statútuma. In: Magyar Kisebbség 3-4. szám, pp. 43-95.

Dabis Attila (2012): A Dél-Tiroli Felszabadítási Bizottság (BAS). In: Pro Minoritate nyári szám., pp. 81-93.

\section{Articles in Refereed Journals in English}

Dabis Attila (2016): Reform of the regional policy, and the sustainability of cultural diversity in the EU. In: ISES Studies on European Integration, Issue 5., pp. 111132.

Dabis Attila (2014): The South Tyrolean Party System. In: Minority Studies 17., pp. 3352.

\section{Other articles in Hungarian}

Sengel Ferenc \& Dabis Attila (2017): Székelyföld területi autonómiája. In: Magyar Idők, III. évf. 60. sz. 2017.03.11.

Dabis Attila (2015): Quo Vadis Skócia, avagy merre kanyarodik az egyenes út? In: Székely Nép 8. szám, 2014. III-IV. - 2015. I-II. negyedév, p. 12.

Dabis Attila (2013): Székely Zászló - ahogy Nyugat-Európából látszik. Válasz Keno Versecknek a Spiegel Online-ban február 9-én megjelent írására. In: Erdélyi Napló, XXIII évf. 7. szám, 2013.02.21, pp. 5., 


\section{Other articles in Foreign languages}

Dabis Attila (2014): Neighbors of Ukraine, values of Europe. Visegrad Insight online, 2014.03.19.

Dabis Attila (2013): Debatte über die Szekler Fahne. Antwort an Keno Versecks Artikel, der am 09.02.2013. im Spiegel Online veröffentlicht wurde. In: sznt.eu, 2013.03.01.

Dabis Attila (2013): A Debate on the Szekler Flag. neweasterneurope.eu, 2013.02.28. 